\title{
The Nemrud Dağ Project: first interim report
}

\author{
Eric M. Moormann and Miguel John Versluys
}

with contributions by Maurice Crijns, Onno van Nijf \& Marlies Schipperheijn, Tesse D. Stek \& Ellen Thiermann and Anne ten Brink

1 Introduction

2 Previous research on Nemrud Dağ

3 A short description of the monument 3.1 The East Terrace

3.1.1 Lay-out and architectural elements

3.1.2 The colossal statues

3.1.3 The stelae and sculptures in tuffit

3.1.4 Ancestor stelae and altars

3.2 The West Terrace

3.2.1 Lay-out and architectural elements

3.2.2 The colossal statues

3.2.3 The stelae and sculptures in tuffit

3.2.4 Ancestor stelae and altars

3.3 The North Terrace

3.4 Building materials

3.5 Preservation, construction and technique

3.5.1 The stelae

3.5.2 The colossal statues

3.5.3 The nomos inscription and other texts

4 The Amsterdam University research

4.1 The SIS (with Tesse Stek \& Ellen

Thiermann)
4.1.1 Goals

4.1.2 How to use the SIS

4.1.3 Block drawings

4.2 Some new observations

4.2.1 Cosmological orientation?

4.2.2 The Lion horoscope: proposal for a new dating (Maurice Crijns)

4.2.3 Chronology: a new dating frame?

4.2.4 The lower ensemble on the East Terrace

4.2.5 The 'Fire Altar' on the East Terrace: true or false

4.2.6 The West Terrace in its oldest shape

4.2.7 The sequence of the colossal statues

4.2.8 Style and iconography

4.3 The pilot survey (with Anne ten Brink)

4.3.1 Introduction

4.3.2 Results

4.3.3 Conclusion

4.4 Epigraphic research (Onno van Nijf \&

Marlies Schipperheijn)

5 Outlook for the next years

Bibliography/Abbreviations

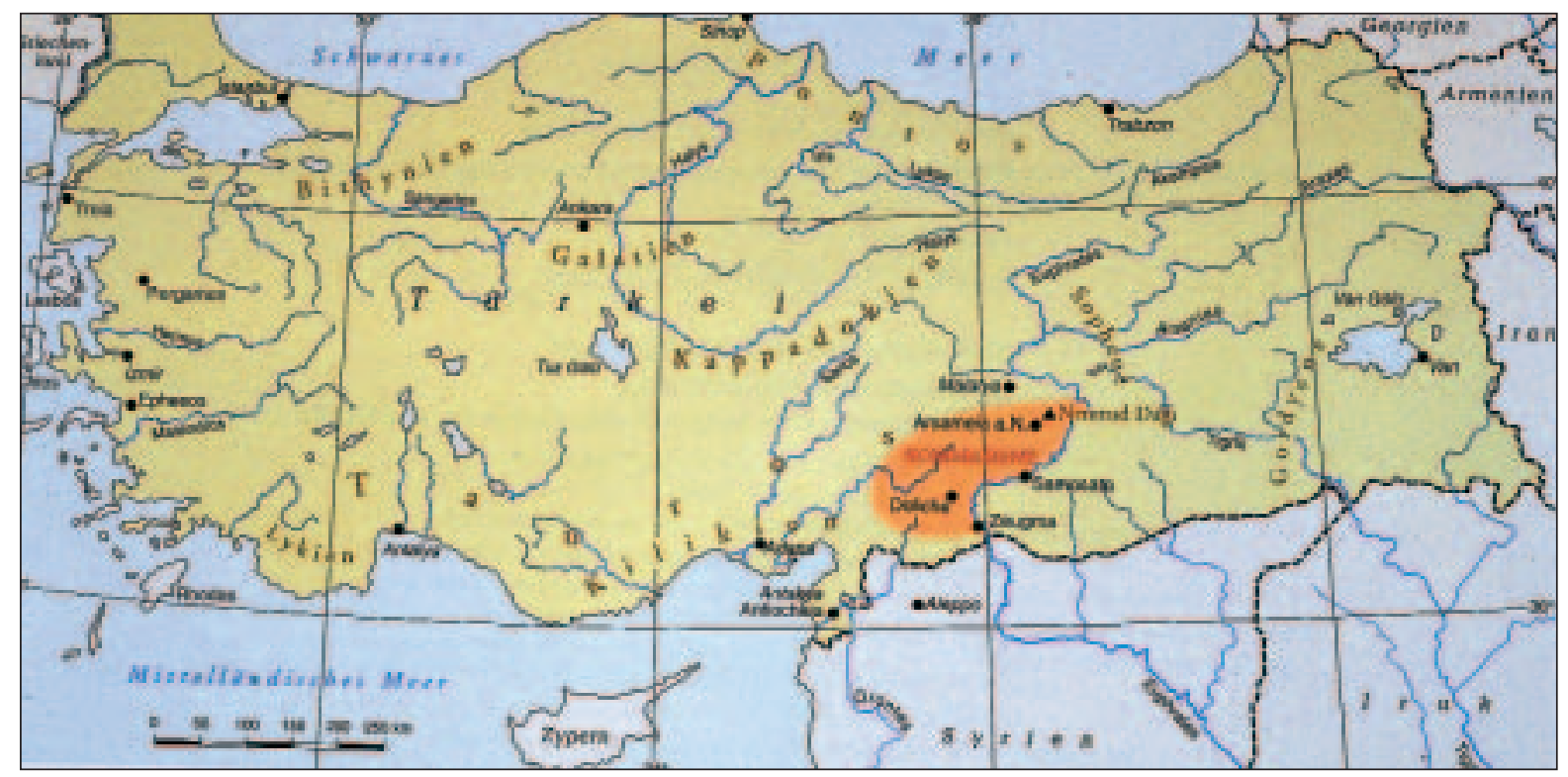

Fig. 1. Kommagene (after Wagner 2000). 


\section{INTRODUCTION}

The International Nemrud Foundation (hereafter INF), established in 1998, has worked for a couple of years to obtain a permit from the Turkish Government to carry out archaeological research on and around the monument of Antiochos I of Kommagene on the mountain of Nemrud Dağ in the province of Adryaman, Southeastern Anatolia, Turkey. The main aim of the Foundation is to protect the monument from further deterioration and destruction as well as to reconstruct the colossal statue groups and some of the relief stelae on the East and West Terraces. In view of the ambitious aims of the project it was deemed necessary to make a new documentation of the remains on the mountain and to study the possibility of a virtual reconstruction.

After a permit had been granted by the Turkish Ministry of Culture to the University of Amsterdam, a team from the Amsterdam Archaeological Centre of this university started research on the $14^{\text {th }}$ of July 2001, the same day as represented on the famous Lion horoscope on the West Terrace (see pp. 97-99). The team was composed of archaeologists, epigraphists, geodesists, construction and AutoCAD engineers. ${ }^{1}$

The 2001 research had several goals. In view of the project's overall goals of preservation and restoration most energy was spent to obtain a documentation as complete as possible, the socalled SIS (Site Information System), which may serve to both students and restorers in the future. Archaeologists could profit from this system for their research. At first impression such a basic documentation of the site might seem redundant, as an impressive monograph of the site was published in 1996 presenting the results of the American excavations directed by Theresa B. Goell in the 1950's, 1960's and 1970's. ${ }^{2}$ However, Goell's results and documentation proved to be problematic in several ways. Besides, we expect that new technology (especially the laser scan) could yield a more fundamental documentation

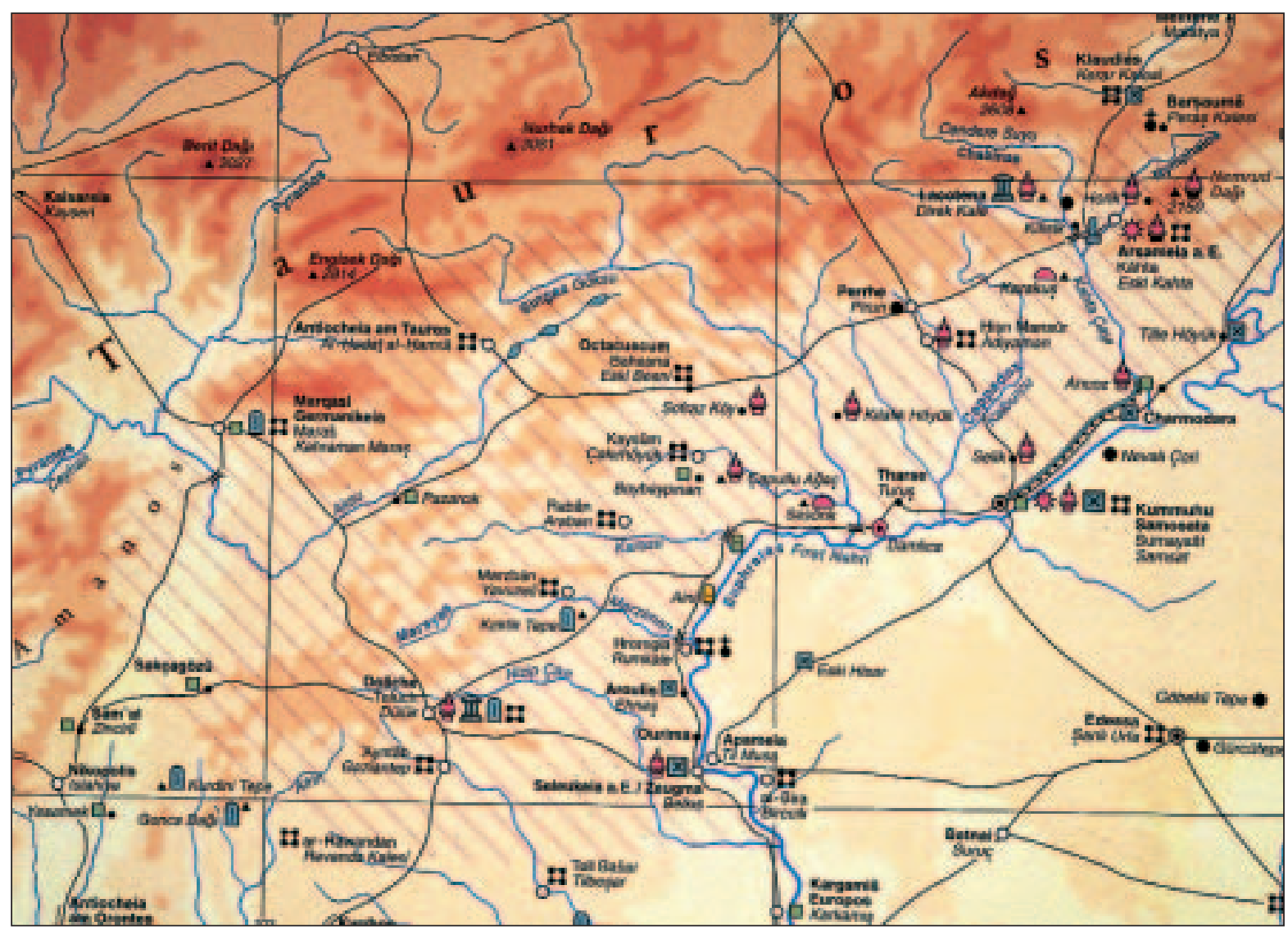

Fig. 2. Map of ancient Kommagene showing the most important archaeological sites (after Wagner 2000). 
of the site than hitherto provided. We had, therefore, to review critically the work of Goell for the compilation of our SIS; our impressions will be published over the next years with the intention to serve as a kind of review article of Sanders 1996.3

Moreover, though concentrating on the terraces and statues proper, the Amsterdam research also made a modest start with the study of the direct context of the monument, i.e. the area of the mountain below the tumulus and terraces. Therefore, we surveyed a part of this area, first of all to see if there were any stray finds that could provide new information for understanding the monument. There is, for instance, a remarkable absence of pottery from the monument itself that could have been preserved on the mountain's slopes. Moreover, we know that this area was incorporated in the conception of the monument by means of guarding animals and entrance stelae. A second aim was to look if a more extensive field survey is feasible.

It has often been noted that despite the unique character of the monument, and the fact that it is one of Turkey's most important archaeological monuments, our understanding of the site, and the state of our documentation are relatively poor. The low interest shown in the site by Classical and Oriental archaeologists, may well be due to the fact that it blends Graeco-Roman and Persian elements, as was suggested by Goell. However, it would seem that Goell herself was partly responsible also, on account of her long delay in publishing the results of her research. For these reasons we felt obliged to provide a detailed account of our intentions, working methods and results on a yearly basis. The results and insights of the campaigns will thus be published each following year in this periodical. These interim reports, offering work in progress and provisionary conclusions, will form the base of our final publication. Obviously, only at that time final conclusions will be formulated.

\section{Previous Research on Nemrud DaĞ}

The remains on Nemrud Dağ, a hill majestically overlooking the anti-Taurus, were discovered in 1881 by the German engineer Karl Sester. ${ }^{4}$ Until that time Kommagene was no more than a name known from historical sources only, studied by the Leiden classicist David Jacobus van Lennep in his $1828 \mathrm{PhD}$ and by Theodor Mommsen in an article of 1876 (fig. 1). ${ }^{5}$ Two short German expeditions by Sester and Otto Puchstein in 1882 and by Karl Humann and Puchstein in 1883 and one Ottoman exploration by Osman Hamdi Bey and Osgan Effendi in 1883 made the monument famous to the world of archaeology at once. The two teams made thorough descriptions of the visible remains and concentrated on the collection of the epigraphic material, especially the large inscription in Greek on the backs of the colossi that informs us about the monument, its use and the intentions of its founder (the nomos inscription, figs. 26-27). Although they do not provide a synthesis, their work remains fundamental.

It took some decades before more thorough investigations started. The German scholar Friedrich Karl Dörner wrote his PhD on Kommagene and travelled to the area from 1939 onwards. He was to become the discoverer or explorer of the main other sites in Kommagene such as the ancestor grave and royal summer residence Arsameia at the Nymphaios (discovered by Dörner in 1953) and the tumuli - hierothesia - of Karakuş and Arsameia at the Euphrates. ${ }^{6}$ Between 1953 and 1973, the American archaeologist Theresa B. Goell conducted a large number of campaigns on Nemrud Dağ.7 Both scholars made restorations and reconstructions of various elements of this complex. The primary aim of Goell's first campaigns was to clear the terraces form the debris, in order to understand the organisation of space. Members of her team worked on aspects like the statuary remains and all fragments of sculpture and epigraphy found during the clearance. The main outcome of Goell's work is that the West and East Terraces were pendants, that contained more or less the same elements. Afterwards, her work focused more and more on the discovery of the tomb of Antiochos, mentioned in the inscription at the back of the statues, Antiochos' nomos.

The pioniering efforts of Dörner and Goell generated a series of other studies on Nemrud Dağ, usually from a historical or epigraphic point of view; such as the studies by Helmut Waldmann and Sencer Şahin. ${ }^{8}$ An important contribution to the debate was made by Jörg Wagner who made the whole region of Kommagene, its history and its archaeological monuments from various periods to his field of study, thereby broadening the background against which a monument like Nemrud Dağ should be studied (fig. 2). ${ }^{9}$

The German and Turkish pioneers of the 1880's were only able to document the visible remains, which they did very well considering the circumstances. They lacked the means to remove the thick layers of gravel from the remains which had rolled down from the tumulus that crowns the 


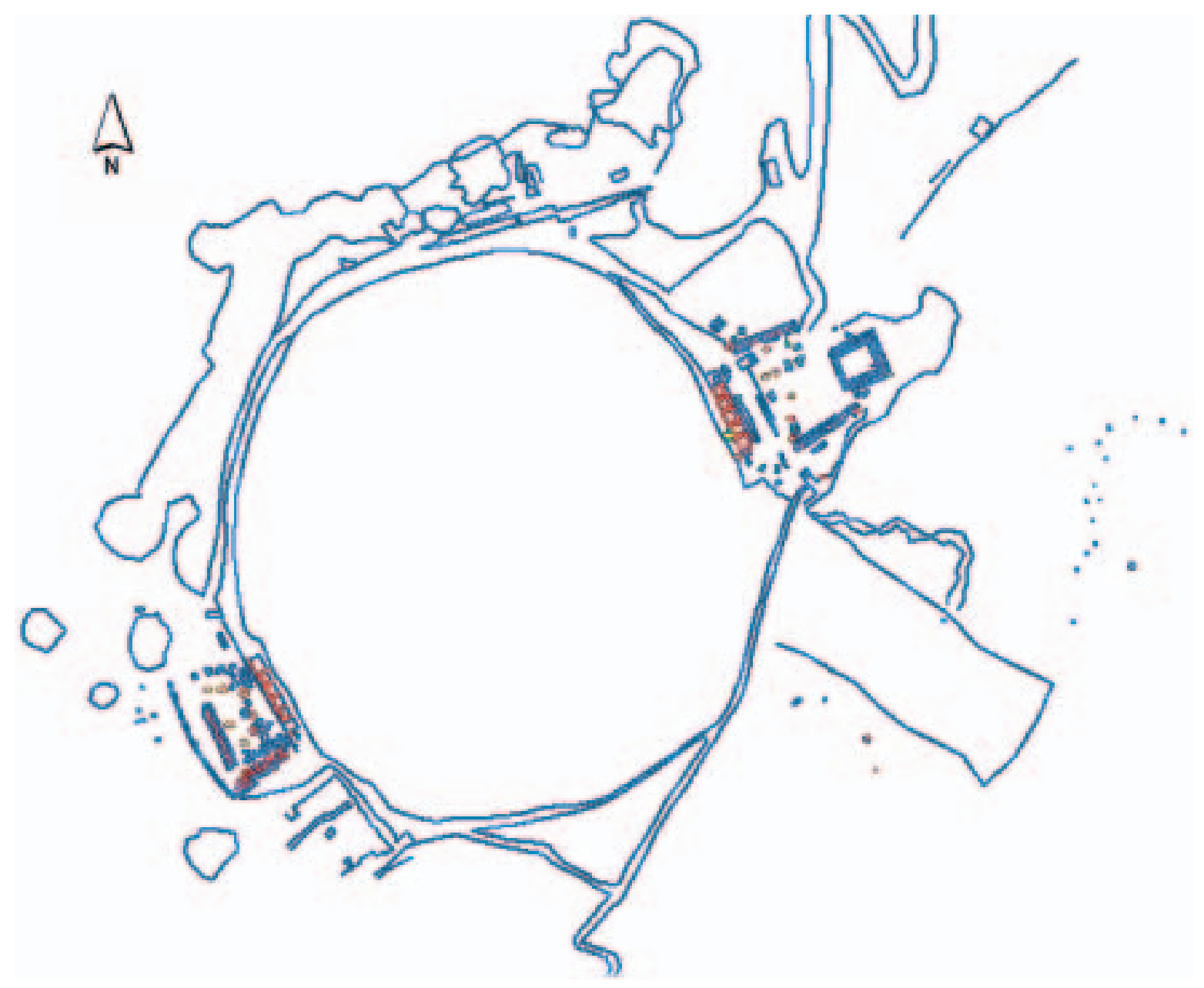

Fig. 3. Nemrud Dă̆: topographical map of the monument (@ INF).

mountain. Their maps, therefore show big blank spots. Dörner did not carry out excavations, but published many important observations. Goell, on the other hand, turned every stone in her quest to find the 'truth' about the monument. 10 She has worked longer on the mountain than any other scholar, but unfortunately she only published short reports, and popular articles, that contained little information on the scope of her project, her working methods, or the result of the project. Her many notes and drafts were collected and published posthumously by Donald Sanders in 1996 (Sanders 1996). In fact this important volume forms the basis for further investigations of the monument.

Before presenting the Amsterdam research and offering some new hypotheses concerning the history and interpretation of the monument, we give a short description of it.

\section{A SHORT DESCRIPTION OF THE MONUMENT}

The monument - named hierothesion in the large inscription on the back of the colossi - consists of a tumulus flanked at three sides by terraces. The tumulus 'erected' on top of Nemrud Dağ suggests the presence of the tomb of Antiochos as mentioned in the inscription. It is formed of the original mountain, partly topped and hewn off on its surface and a covering layer of gravel. Small square terraces were constructed to hold the gravel. ${ }^{11}$ The height of the tumulus is about 50 metres (fig. 3).

The workers started with cutting off the northwest flank between the North and the West Terraces. Subsequently the gravel that was produced this way was transported to 'deposits', viz. the slopes between the two terraces mentioned. Then they constructed artificial terraces and 


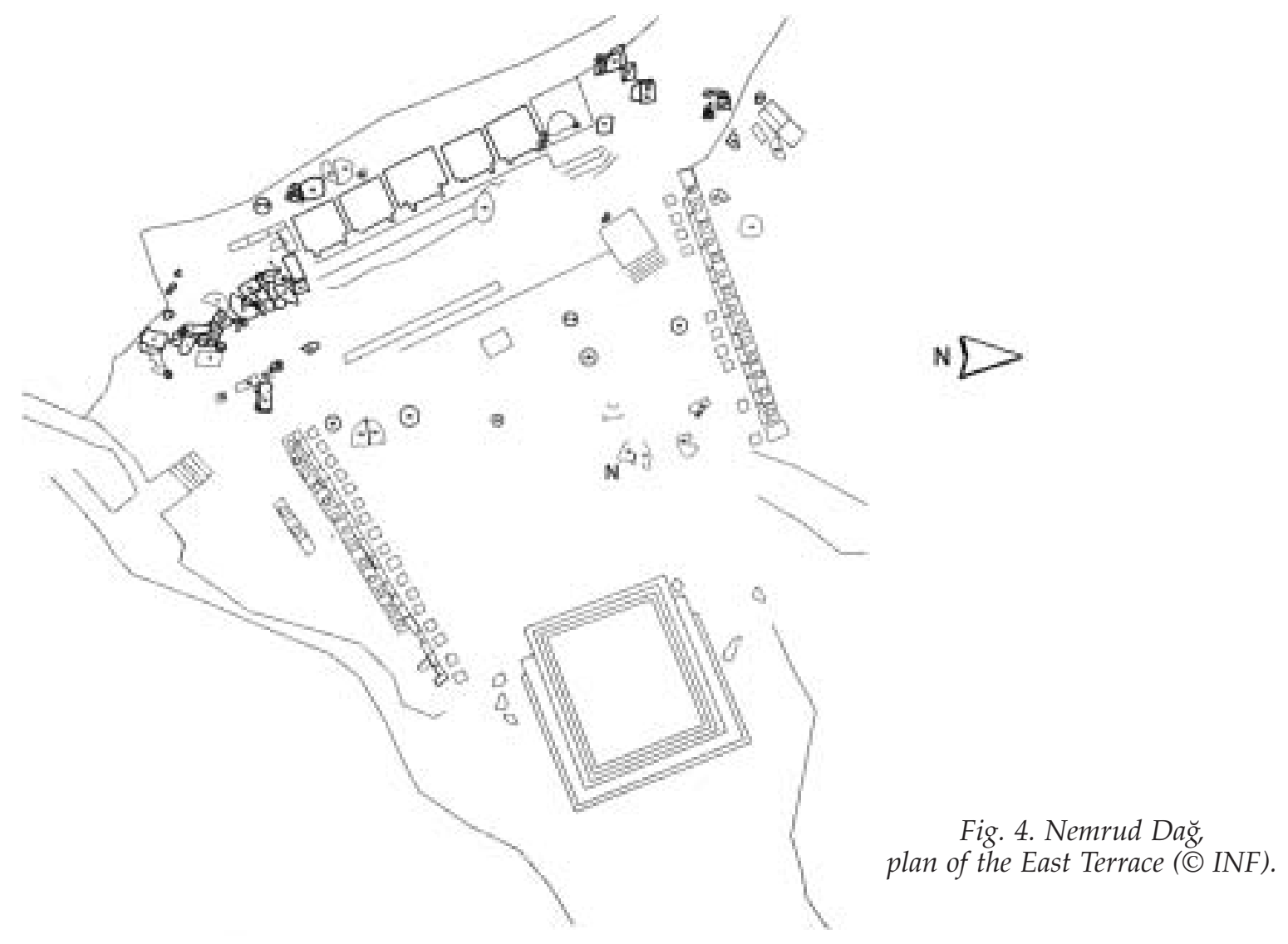

started chopping the top. The gravel was spread out towards the lower layers and was partly kept in place by the artificial banks. ${ }^{12}$ The deposits were used to backfill the empty spaces. The part of the mountain still standing at the south side of the West Terrace was not entirely used for the gravel production. It was, however, gradually topped of as can be seen from cuttings in the rock. Maybe some kind of platform was constructed. The large amount of gravel still visible at the south side is an extension of the tumulus.

As has become clear, mainly from Tom Utecht's research, the tomb is probably not located in the tumulus itself but either under it or at some place in the vicinity. ${ }^{13}$ At four sides Goell made holes into the mountain to discover the tomb. The results of explosions with dynamite are clearly observable behind the colossi on the East and the West Terraces.

In the description of the terraces, we will each time first describe the setting itself, before shortly introducing the architectural elements. Matters of specific interest deserving more attention, like, for instance, the colossal statues will be treated in separate paragraphs. We have tried to keep the text as descriptive as possible, largely drawing on the information provided by the work of Goell and our own observations in the field. Our critical discussion of several aspects and some new hypothesis can be found in paragraph 4.2.

\subsection{The East Terrace}

\subsubsection{Lay-out and architectural elements}

The East Terrace is a rectangular area that has been flattened by cutting off part of the mountain. At the west side it is bordered by a stepped area cut out from the rock. On top of this, on a second plateau largely also hewn out from the mountain, the colossal statues are erected. On the east side border, opposite to this ensemble, Goell has reconstructed a stepped structure in tuffit; the so-called fire altar. She did so on the basis of the presence of stepped structures at the north and south and a retaining wall at the east, already seen by Humann and Puchstein (see further paragraph 4.2.5). At the south side a steep mountain slope begins; to the north there is a path leading to the North Terrace (fig. 4). 


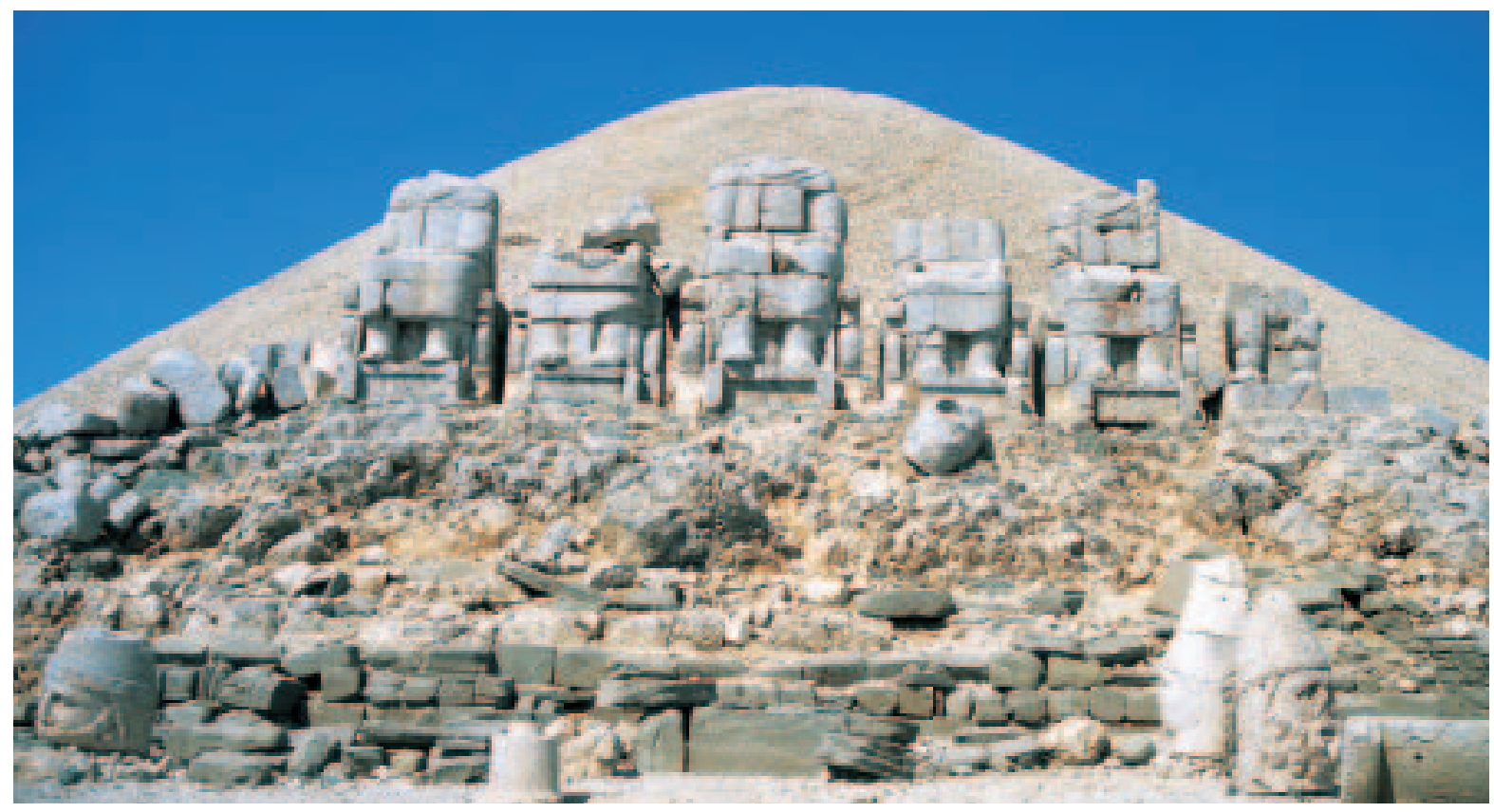

Fig. 5. Nemrud Dă̆, East Terrace, overview (2001, photo E.M. Moormann).

At the south side of the terrace there is an entrance: eleven steps (of which nine are preserved) have been cut out in the living rock. The rest of the stair makes five turnings of $90^{\circ}$ as one can observe in the cutting of the rock downwards the slope. The precise form cannot be reconstructed unless by voiding the space from the masses of gravel. A small platform, in line with the eleven steps, seems to command the progression of the stair. The main entrance to the terrace seems to have been at the north-east side: a socalled procession road, hiera hodos, ended just below the terrace at this side. The existence of this road is certain by the find of an inscribed entrance stele on the slope, besides one can still see part of the path hewn out from the rock.

Bases for stelae and corresponding altars in front of them line the north and south borders of the terrace (see further paragraph 3.1.4).

Goell reported the presence of various tuffit animals on the terrace. She reconstructed the presence of two pairs of an eagle and a lion on or at the so-called fire altar. Nowadays a lion (186 $\mathrm{cm} \mathrm{H}$ ) standing next to the stepped structure and fragments of two eagles along the slope rest from this adornment. The passway to the North Terrace would also have been decorated with a large eagle of tuffit. No remains of this are visible anymore.

Lastly, it must be noted that the whole setting is irregular and that there are no precise axes and square angles used; as already remarked by Wolfram Hoepfner who suggests that a certain 'Naturnähe' was looked for (fig. 5). ${ }^{14}$

\subsubsection{The colossal statues}

Main feature of the East Terrace is a row of nine colossal statues: five statues of (semi-)gods flanked at both sides by a lion/eagle pair. The podium on which the colossal statues stand has two steps in front, hewn out from the rock. At the north there are three steps, probably to be combined with those found by Goell at the terrace itself and leading to the reconstruction of stairs. The extreme south and north sides of this podium have been damaged and the statues of the lion and the eagle at the south and that of the lion at the north have completely tumbled down (figs. 5-6).

At the back of the statues a path of $3.5 \mathrm{~m}$ width has been spared out. By this way the nomos, inscribed on the lower blocks of the statues, could be reached. The path runs behind the statues along the west side, not only giving access to those who wanted to read the inscriptions on the backs of the statues, but maybe also used for other purposes in the rituals (fig. 7).

The largest figure, Zeus-Oromasdes, stands in the centre. He is flanked by Apollo-Mithras-HeliosHermes and Artagnes-Herakles on his left and Kommagene and Antiochos on his right (for this 


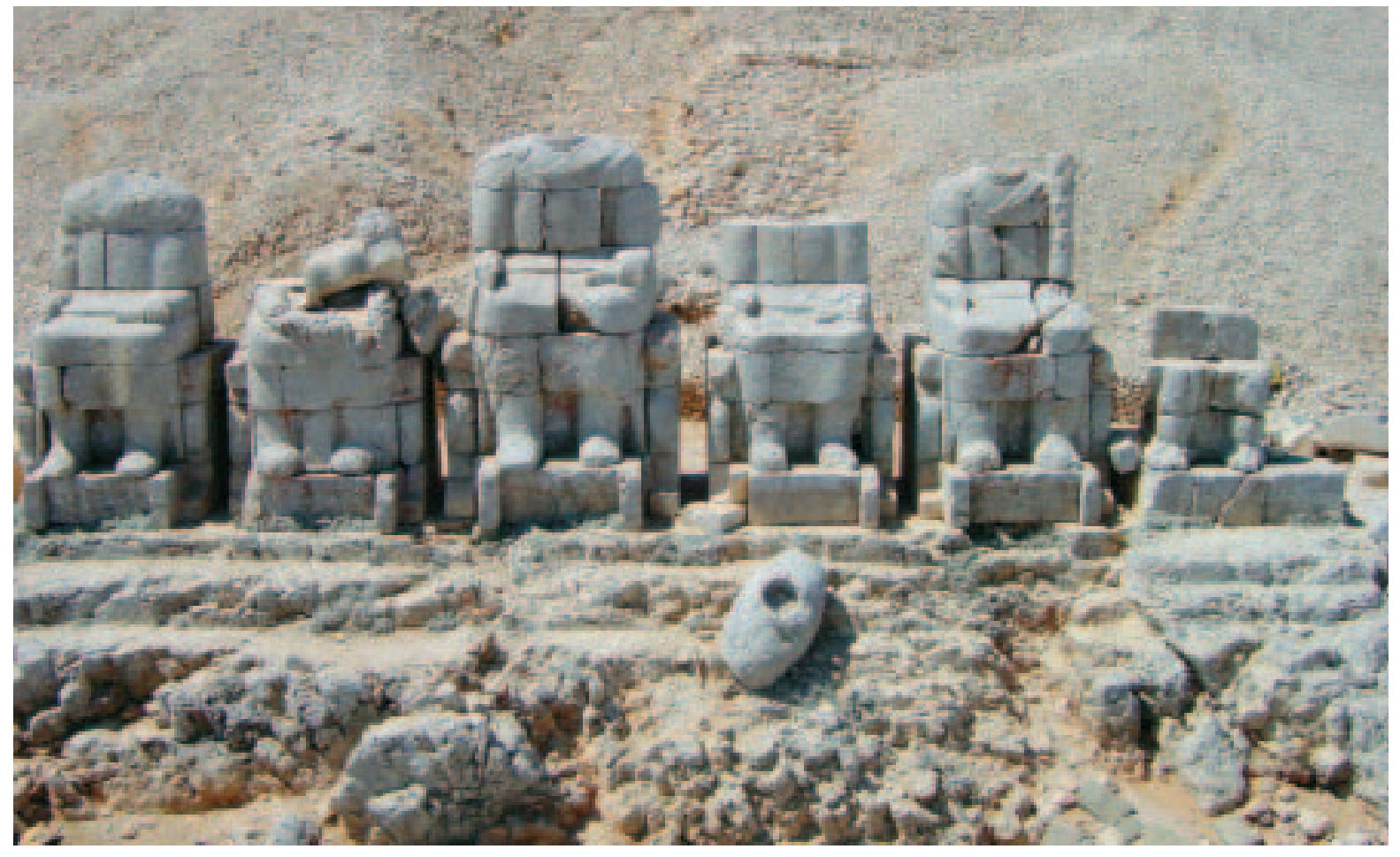

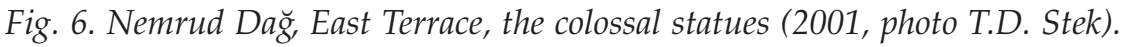

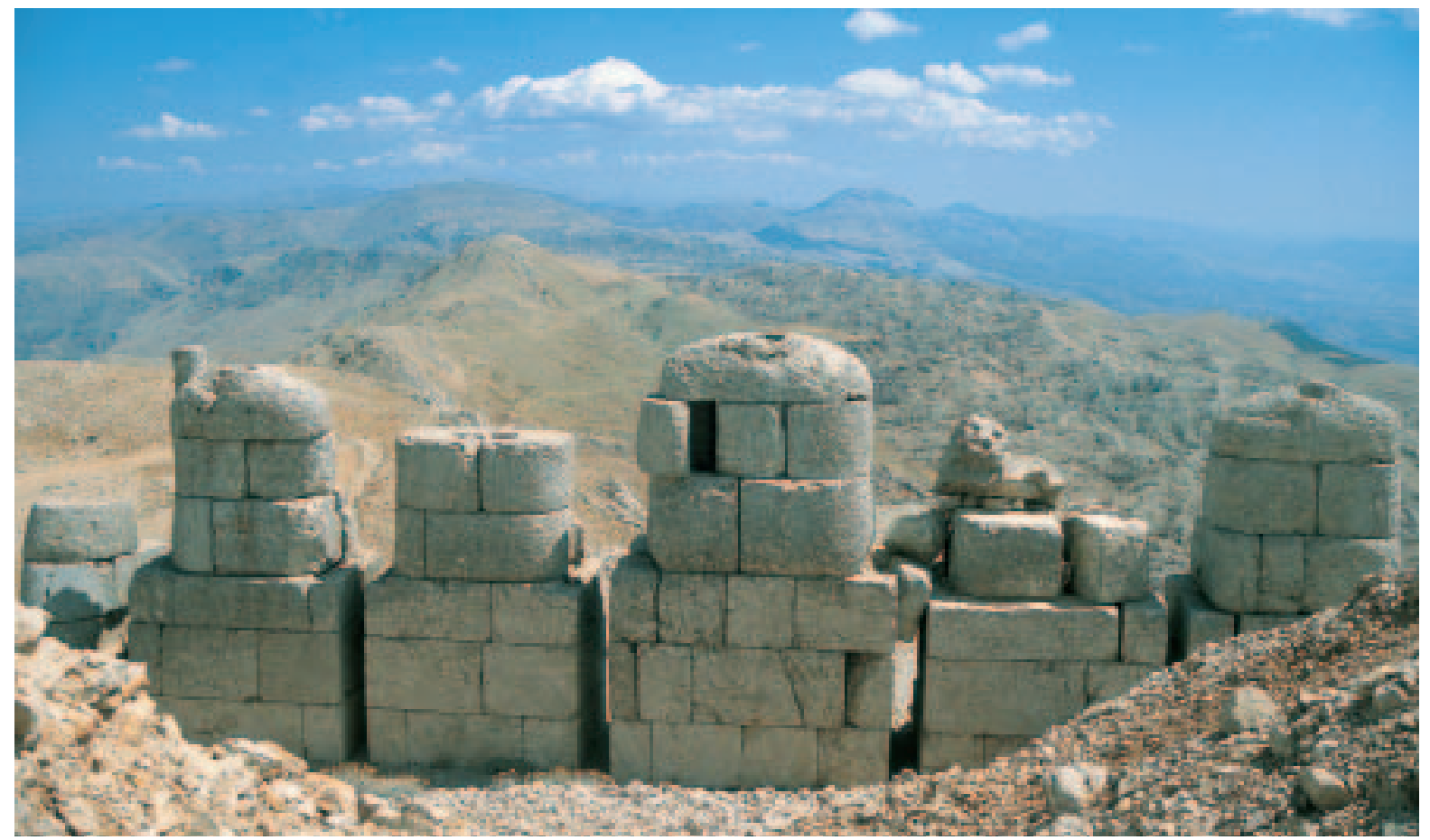

Fig. 7. Nemrud Dă̆g, East Terrace, the back of the colossal statues with the path (2001, photo E.M. Moormann). 
sequence of the statues cf. further section 4.2.7). The different statues are named in the nomos inscription. ${ }^{15}$ At both ends a standing eagle and a squatting lion have been placed.

The figures are seated on huge thrones, their feet resting on footstools standing between the throne's legs. They do not show any movement; Zeus and Kommagene only have the right foot set forward. The statue of Zeus protrudes some $21 \mathrm{~cm}$ in respects to the other figures. The pairs of animals share their base and are worked in the round. The colossi have a basis of their own, formed by the feet of the throne and the footstool in front. ${ }^{16}$ The backs are summarily rendered. The lower three tiers, bearing the inscription, are plain flat walls. The upper layers have rounded outlines and show no details. The coarseness of the modelling of the bodies contrasts to the precise and detailed working of the heads (figs. 8-9).

The five figures of (semi-)gods are composed of seven or eight horizontal tiers of limestone blocks, from bottom to top: 1) footstool; 2) feet and legs until lower edge of tunic; 3) legs up to knees clad in long garment; 4) lap and forearms; 5) breast and upper arms; 6) shoulders; 7) head; 8 ) top gear. Tiers 6-8 are monolithic. The eighth level includes Kommagene's kalathos, the tips of the tiaras of Zeus and Apollo, whereas Herakles lacks such an extra layer. The other tiers can be variously composed of two or more blocks.

The five lower layers of the colossi are still intact. The figure of Kommagene has, apart from her kalathos lying in front of the lower plateau, been preserved completely, until it came down, according to Goell probably by lighting, between 1963 and 1967. The head and fragments of the back now lie behind the statues. Here is also standing the head of Antiochos. The heads of the other figures and blocks belonging to the animals are scattered over the East Terrace.

The dress of the figures is barely detailed and shows few folds apart from the shoulders where the tips of the mantle have been put together with a buckle. The male dress is oriental: boots, trousers, long-sleeved tunic and cloak. Kommagene has the Greek chiton and himation, of which some folds are indicated near the knees. The mouths are parted and the eyes are suggested to look upward, showing a certain degree of (Hellenistic) pathos. The male gods' tunics end below the knees and a tip of the mantle is indicated by one fold at the sides of the feet. Other folds can be seen in the lap and (diagonally) on the breast. Kommagene's long dress falls down between the legs and its drapery fills this space. The feet are shod in sum-

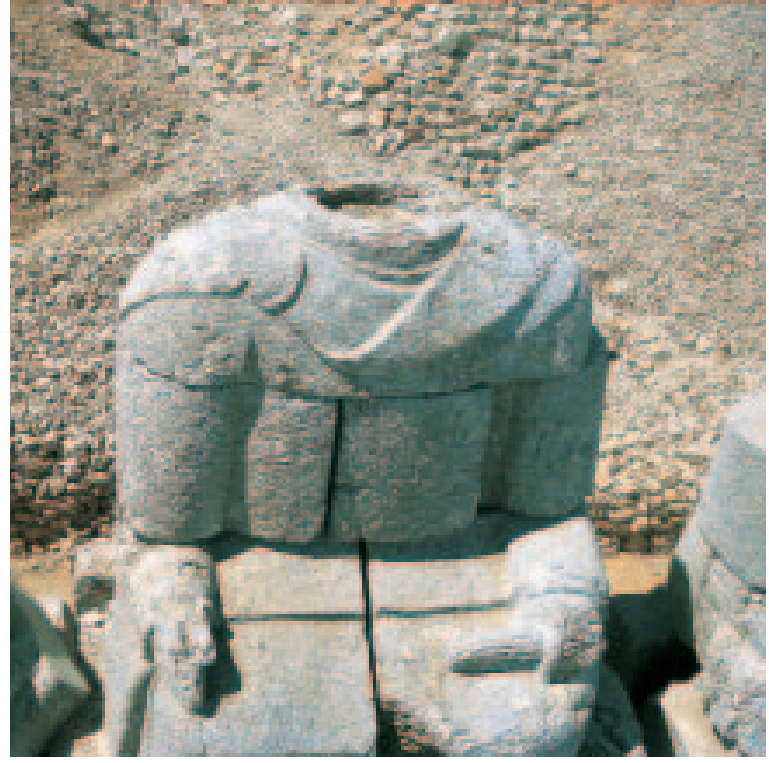

Fig. 8. Nemrud Dă̆, East Terrace, statue of Zeus, upper part as standing (2001, photo T.D. Stek).

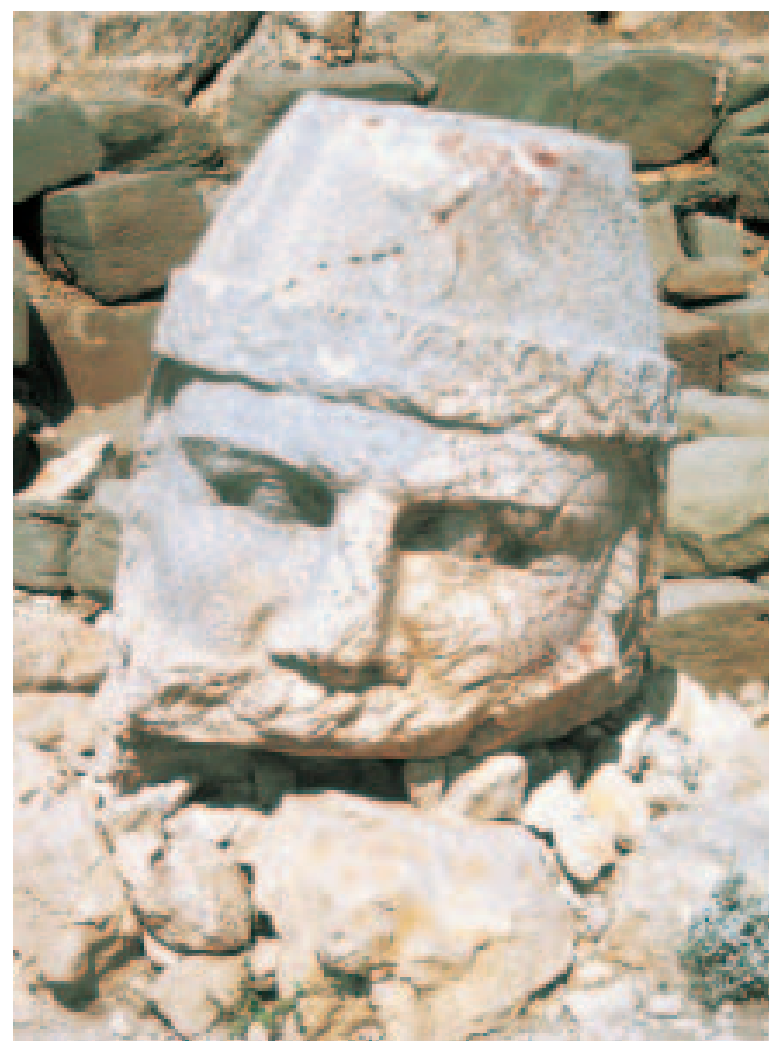

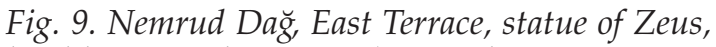
head lying on the terrace (2001, photo E.M. Moormann). 


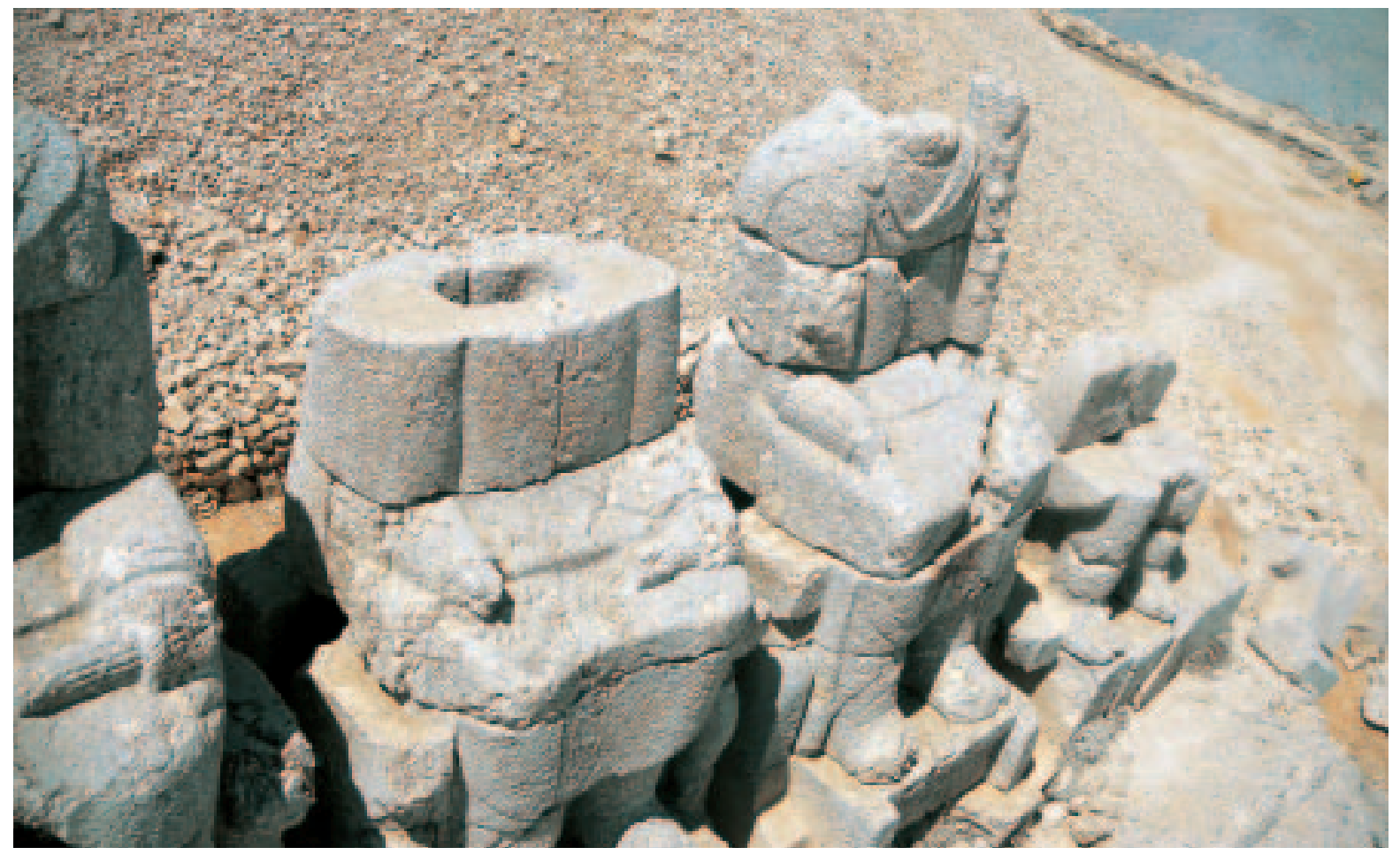

Fig. 10. Nemrud Dă̆, East Terrace, the statues of Zeus (partly, left), Apollo, Herakles and Eagle (2001, photo T.D. Stek).

marily worked boots with laces and lappets. Kommagene has her hair parted in the middle and combed backwards. Her ears are adorned with long earrings. She is crowned with a thick wreath composed of corn poppies in the centre and fruits, mainly pomegranates and grapes to the sides. A veil covers the back of the head and a kalathos, now standing on the terrace, was once on top of the head.

Antiochos, Zeus and Apollo have a bundle of weed, the so-called barsom in their left hand on their laps. ${ }^{17}$ Herakles sports his club with his left hand against his shoulder and Kommagene does the same with the cornucopia. Her right hand holds a bunch of fruit in her lap.

The heads look brighter of colour than the rest of the figures (this colour is also predominant on the West Terrace), which may be due to the different processes of weathering. The heads of Herakles, Kommagene and the northern eagle show numerous small cavities in the surface caused by algae.

Fig. 11. Nemrud Dăg, East Terrace, statue of Apollo, head standing on the terrace (2001, photo E.M. Moormann).

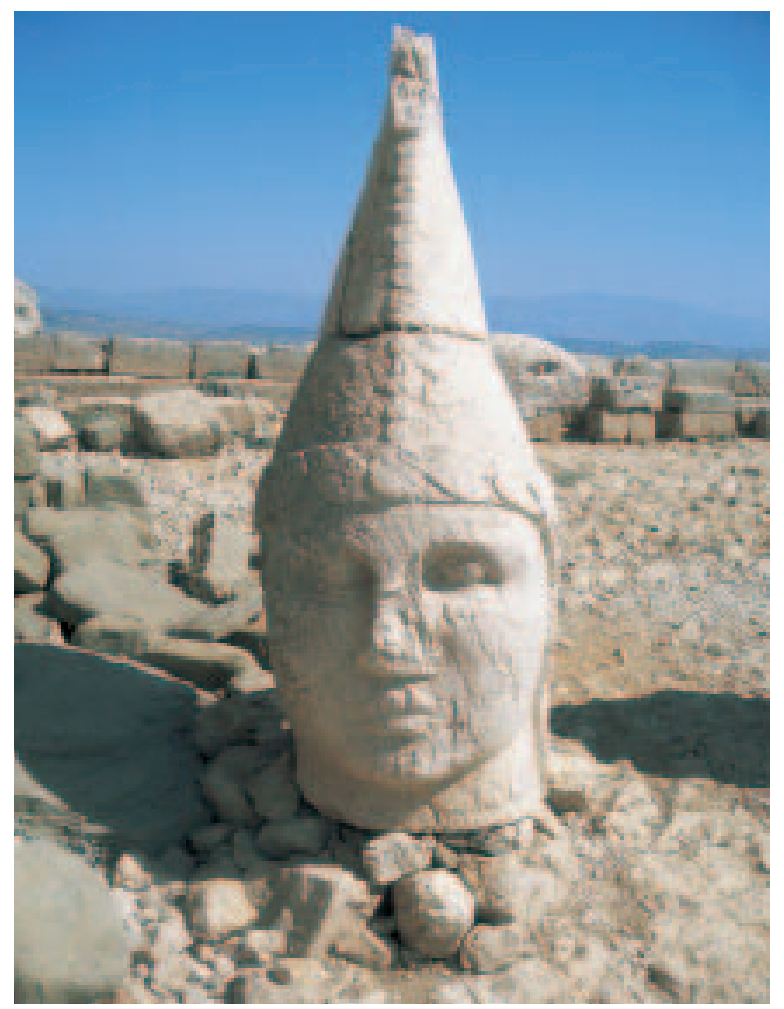




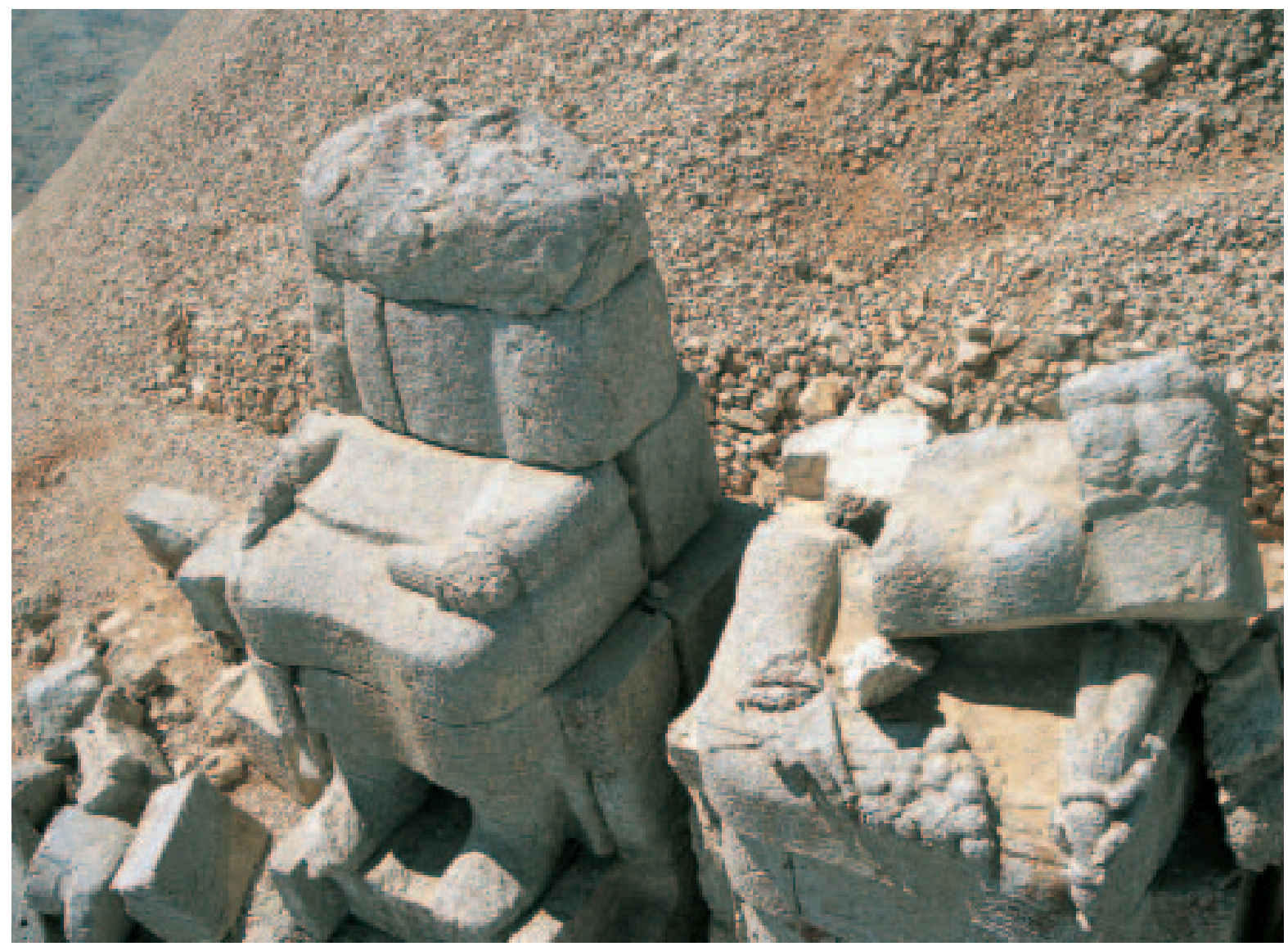

Fig. 12. Nemrud Dă̆, East Terrace, the statues of Antiochos (left) and Kommagene (2001, photo T.D. Stek).

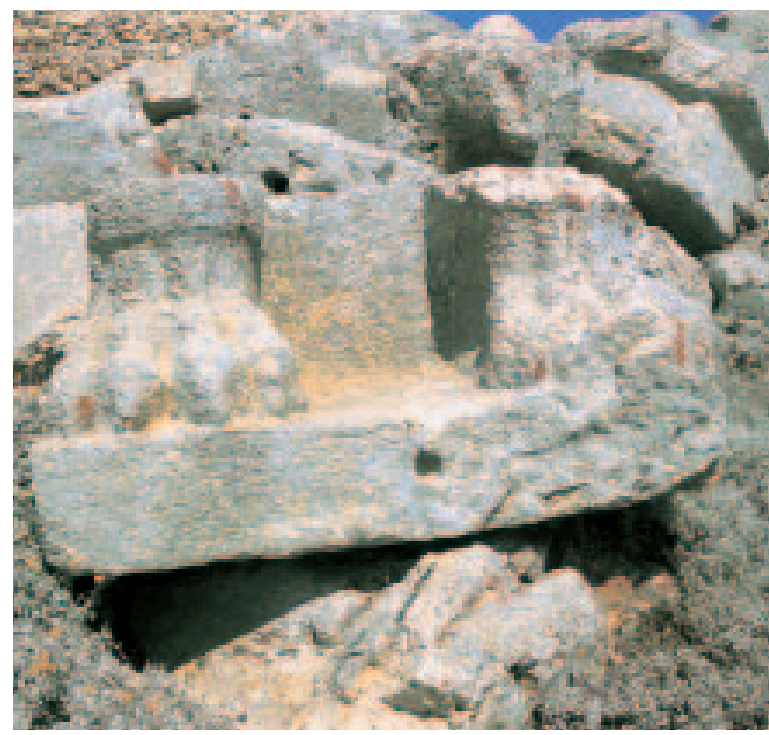

Fig. 13. Nemrud Dağ, East Terrace, the forepaws of the southern side Lion (2001, photo E.M. Moormann).
The two eagles are represented standing erect, with the large feet with five toes protruding over the base. Feathers are not indicated and the birds' surface is entirely smooth. The heads look grim with - as it were - a frown created by a bulging piece of flesh over the inner corners of the wellarticulated almond-shaped eyes. The lions are seated on their hind legs; the tail is curled at the outside of the row, over the paw of these legs. The forepaws show four toes and are adorned with a metal ring (fig. 13). The mane is carefully worked on the breast between the legs and on the head and back. Both heads are badly damaged but look similar to those preserved on the West Terrace: rather friendly, with open fangs, tongue jutting out and upper row of teeth visible.

\subsubsection{The stelae and sculptures in tuffit}

A podium has been cut out of the rock in front of the statues. In front there are tuffit steps made from blocks placed against the prepared rock. 
Goell reconstructed three steps. Sanders however, in his examination of Goell's evidence, gives the number of two steps and proposes good arguments to support his view. ${ }^{18}$ Goell reported that fragments of large stelae similar to those on the West Terrace have been found. She offers a reconstruction of a Lion horoscope and of the four dexiosis stelae in front of the statues on one of the tuffit steps (see section 3.2.3). At the southern side of the podium four sockets for stelae have been hewn out in the rock; the third from the south is twice as large as the others. Reasoning from the find of fragments of a stele showing a coronation found on the podium, Goell reconstructed five socalled stephanophoros stelae. She interpreted this coronation scene as the transmission of power by Mithradates I to Antiochos; Sanders suggests a similar ceremony, but with Antiochos and Mithradates II as protagonists. ${ }^{19}$ The rock behind the platform with the stelae has been left unworked, maybe because it remained invisible behind the large orthostates.

At the north side of the podium a flight of nine steps in tuffit has been constructed by Goell, based on a protrusion in the lower line of steps. It is situated in line with a stepped structure hewn out in the rock at the top, in front of the base for the right eagle and lion. The blocks may belong to the podium structure; it can no longer be checked. At the south one step is constructed in the same way; but as far as we can see now, there is no flight of stairs at this side. ${ }^{20}$

In front of the podium Goell reconstructed a so-called 'sacrificial block altar' parts of which are still in situ. The supposed altar is made from tuffit blocks and slabs, material that lays scattered all over the area. Sanders already notes that this structure might not be original. The find of ashes and other material in the structure suggests that local shepherds built the structure for own use from blocks and slabs lying around. ${ }^{21}$

\subsubsection{Ancestor stelae and altars}

As said, bases for stelae and corresponding altars in front of them line the north and south borders of the terrace. The material used is limestone; the northern row contains tuffit blocks in the rear side of the basis. ${ }^{22}$ The north series of altars starts from the mountain and counts 14 bases and 14 altars. The bases count two rows of blocks, always 14 pieces. Every altar is composed of two tiers: at the bottom two rectangular blocks, at the top a square one. The altars measure approximately 80-85 (height) $\times 70-75 \times 70-75 \mathrm{~cm}$. The (originally) 15

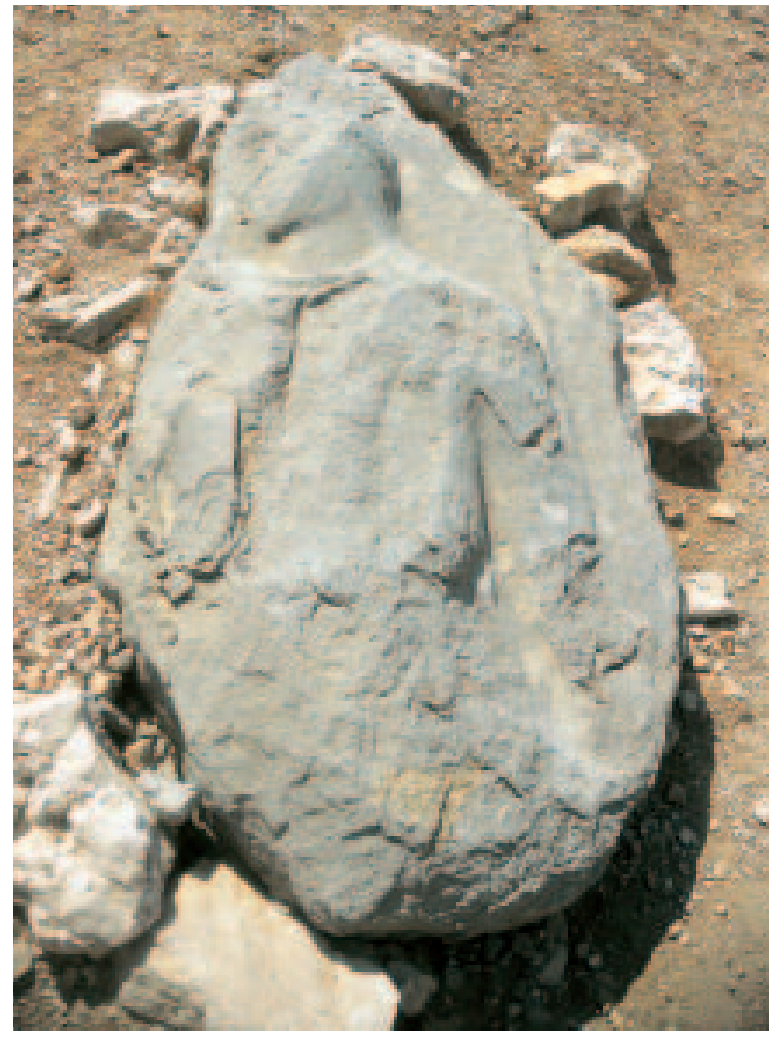

Fig. 14. Nemrud Dă̆, East Terrace, ancestor stele (2001, photo E.M. Moormann).

stelae standing here depicted the Persian and Kommagenean ancestors from whom Antiochos claimed to descend (fig. 14). Behind this row of stelae, which must have given the impression of a sculptured wall, there is a plinth with three stelae bases. The southern series contains 17 altars, whereas 13 bases for stelae have been preserved. The arrangement and measurements are equal to those of the opposite side. Here the 17 claimed Greek and Seleucidian ancestors of Antiochos were depicted. Behind this row, at the south-west corner of the terrace, three bases and corresponding slabs in tuffit are badly preserved.

\subsection{The West Terrace}

\subsubsection{Lay-out and architectural elements}

The West Terrace is a flat space partly cut out of the mountain, partly natural and partly constructed artificially. At the eastern side there are the tumulus and, like on the East Terrace, in total nine colossal statues. Five large stelae, the socalled Lion horoscope and four dexiosis stelae 

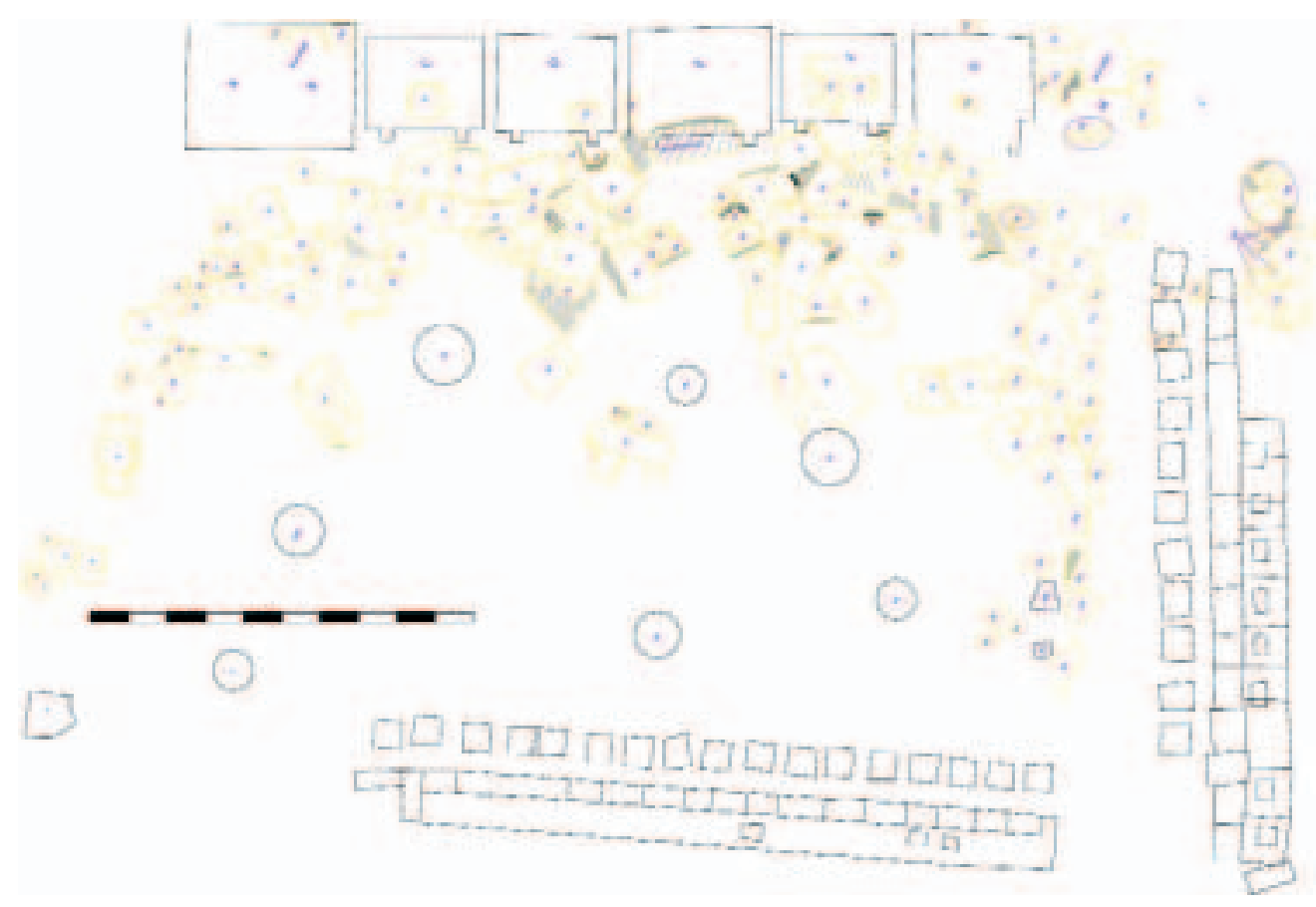

Fig. 15. Nemrud Dă̆, plan of the West Terrace (@ INF).

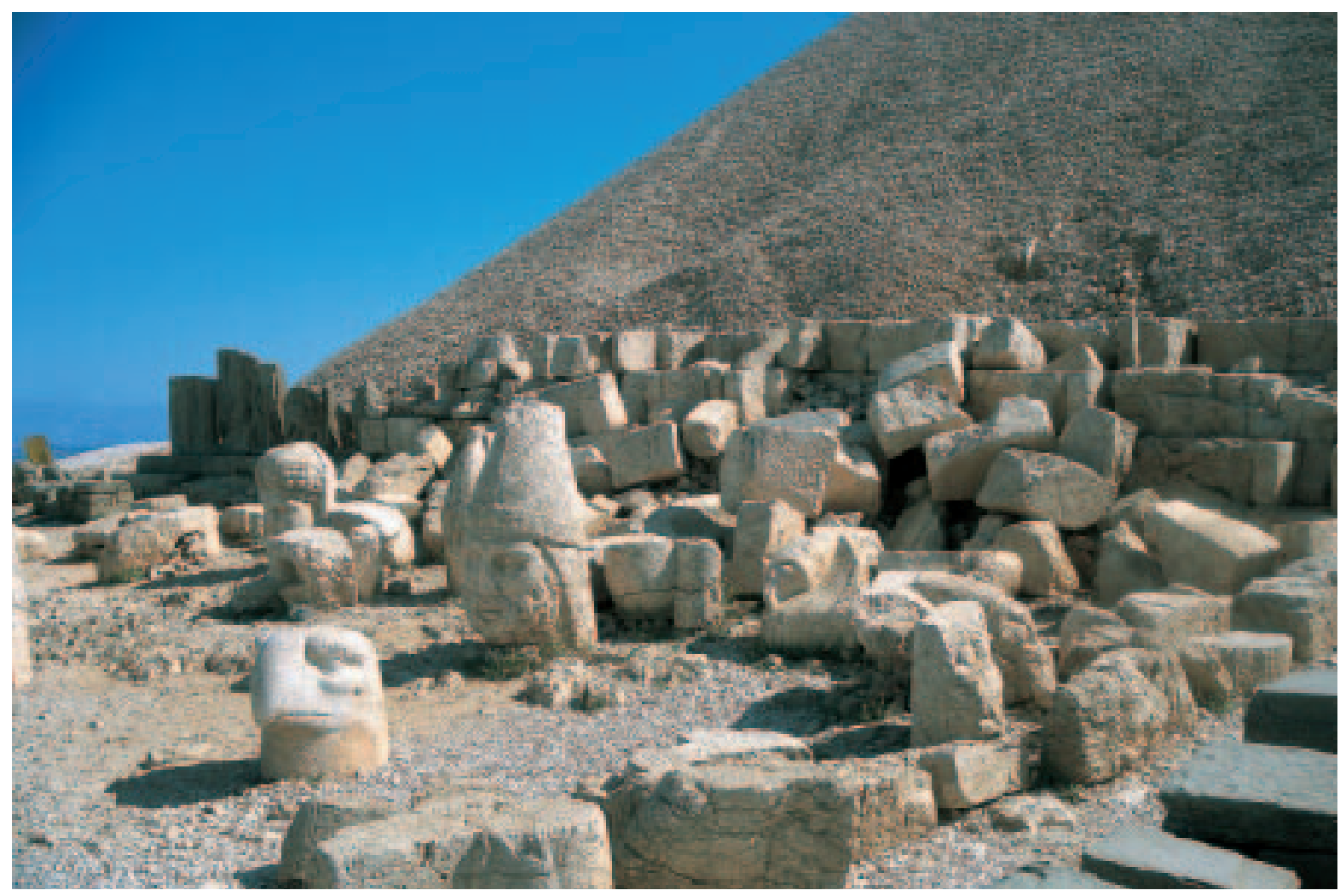

Fig. 16. Nemrud Dă̆g, West Terrace, overview from South (2001, photo E.M. Moormann). 


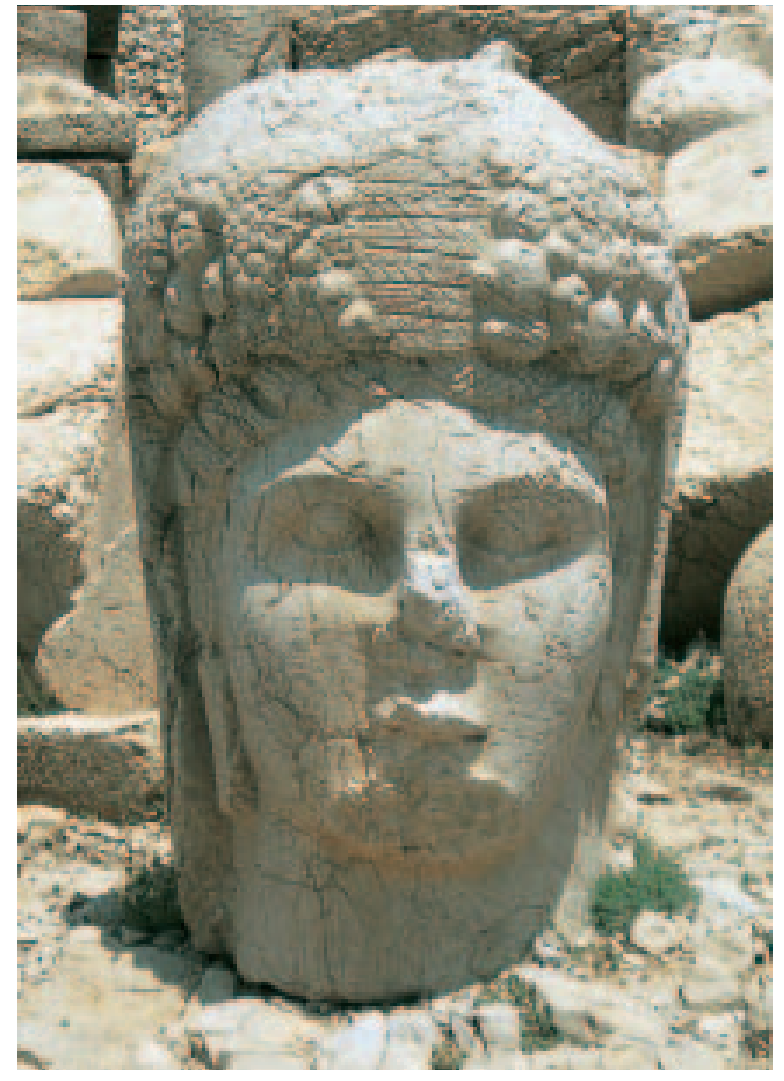

Fig. 17. Nemrud Dağg, West Terrace, statue of Kommagene, head standing on the terrace (2001, photo E.M. Moormann).

showing the king shaking hands with each of the four gods, are standing beside the row of statues to the north (see pp. 98-99). These five stelae were flanked at both sides by a lion/eagle pair as well. The south and (contrary to the East Terrace) the west sides are occupied by bases for tuffit stelae with altars in front of them. As on the East Terrace, the south side originally contained an orthostate wall of 15 stelae showing the 'Eastern' ancestors; in this case the western side showed the 17 'Western' ancestors (figs. 22-23). The northern side provides an access to the northern and the eastern terraces. Here Goell found a plinth with three socles and two altars in front. She also reports the existence of relief fragments. ${ }^{23}$ She thus reconstructed three or five stephanophoros stelae as on the East Terrace. Also at this north side, at the beginning of the slope, there was a large statue of a lion standing on a platform. Part of this guardian animal and his base are still in situ. The open area between the base of the statues and the ancestor altars is now full of blocks fallen down from the

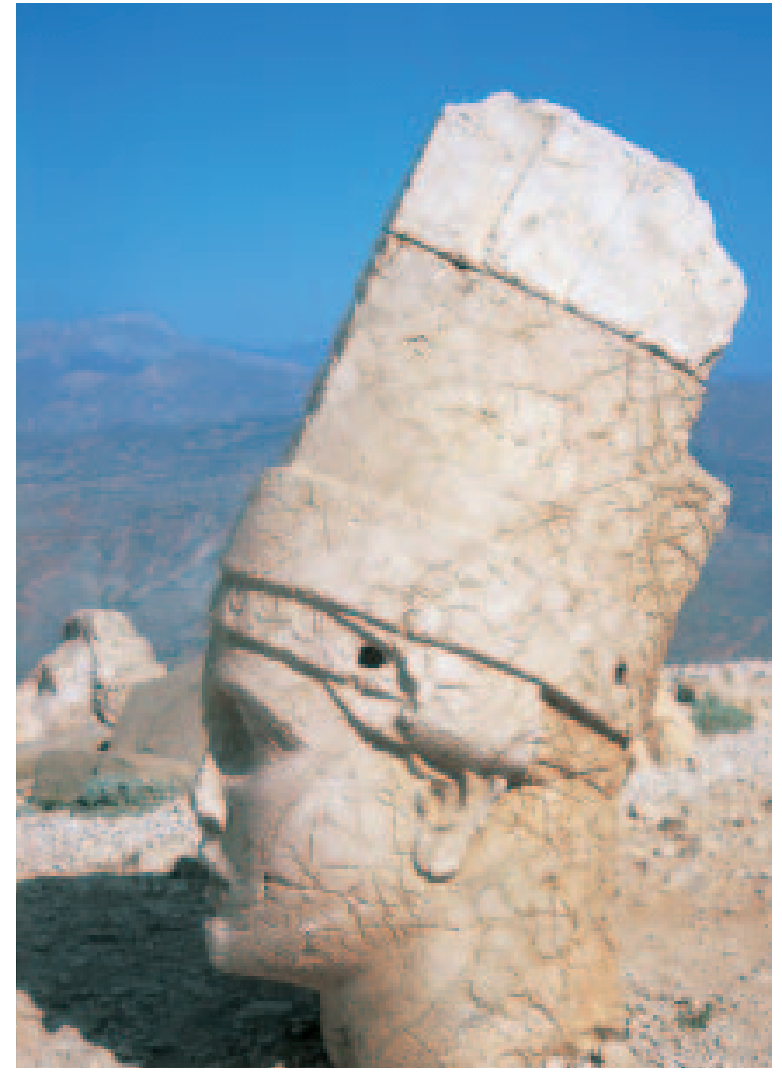

Fig. 18. Nemrud Dăg, West Terrace, statue of Antiochos, head standing on the terrace (2001, photo E.M. Moormann).

statues whereas it must have been an empty space. Goell mentioned an altar/offering table in front of the statues; this is, however, not visible.The structure that can nowadays be seen in front of the stelae (fig. 20, left) seems not original; we can not distinguish five altars that were suggested by Sanders. ${ }^{24}$ There are no traces of paving. The living rock rises considerably in some spots.

A path runs behind the stelae and statues along the east side, similar to that on the East Terrace. To the west, the circular path around the tumulus is hewn out in the rock.

The main entrance to the terrace was provided by the hodos coming from the direction of Arsameia; fragments of an entrance stele had been preserved, as well as its socle (see section 4.3.2).

\subsubsection{The colossal statues}

The disposition of the gigantic statues is identical to the East Terrace, which is of great help in reconstructing them. ${ }^{25}$ There are a few differences in the 


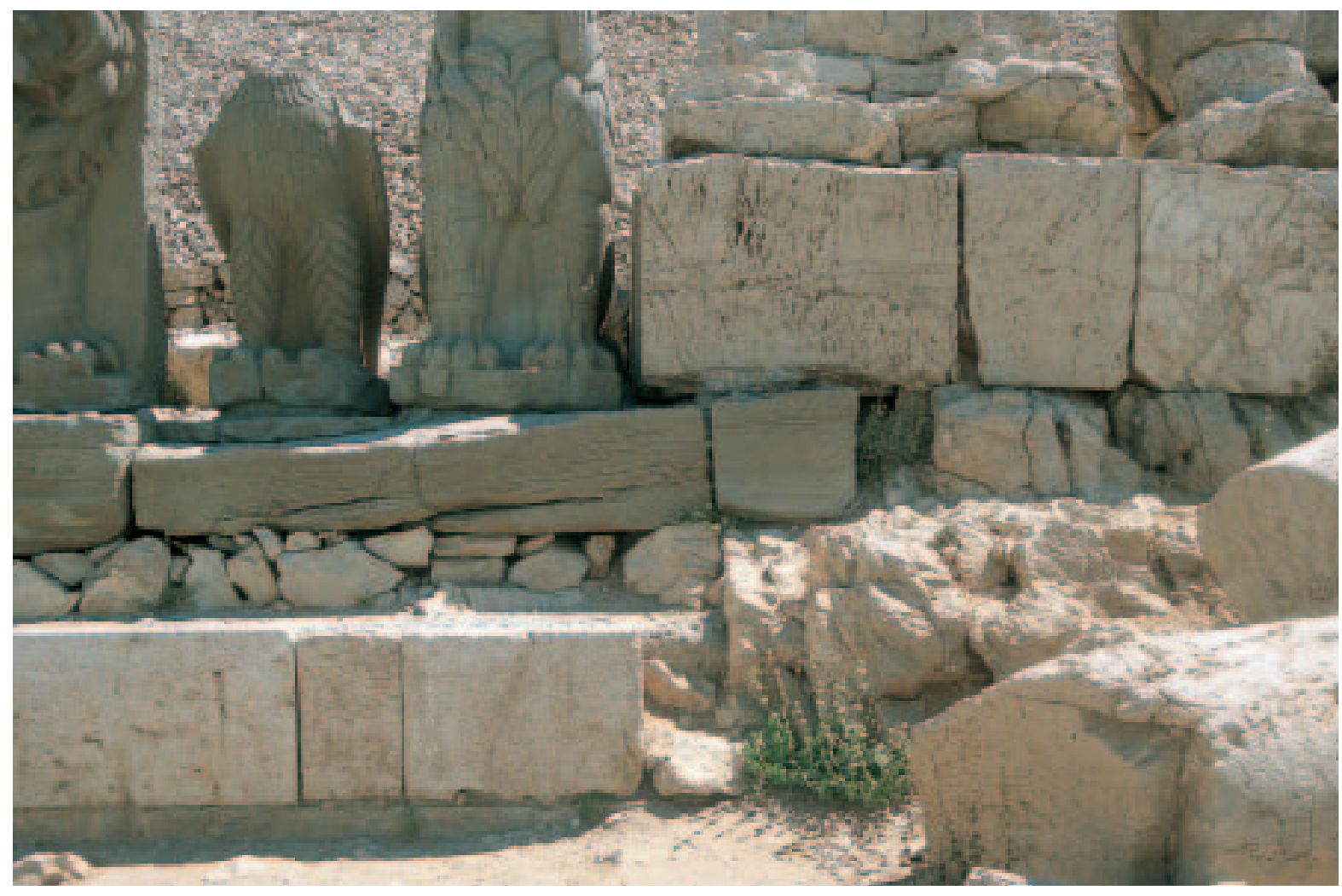

Fig. 19. Nemrud Dăğ, West Terrace, detail: the base of the colossi covering the base of tuffit slabs of the stelae and sculptures (2001, photo E.M. Moormann).

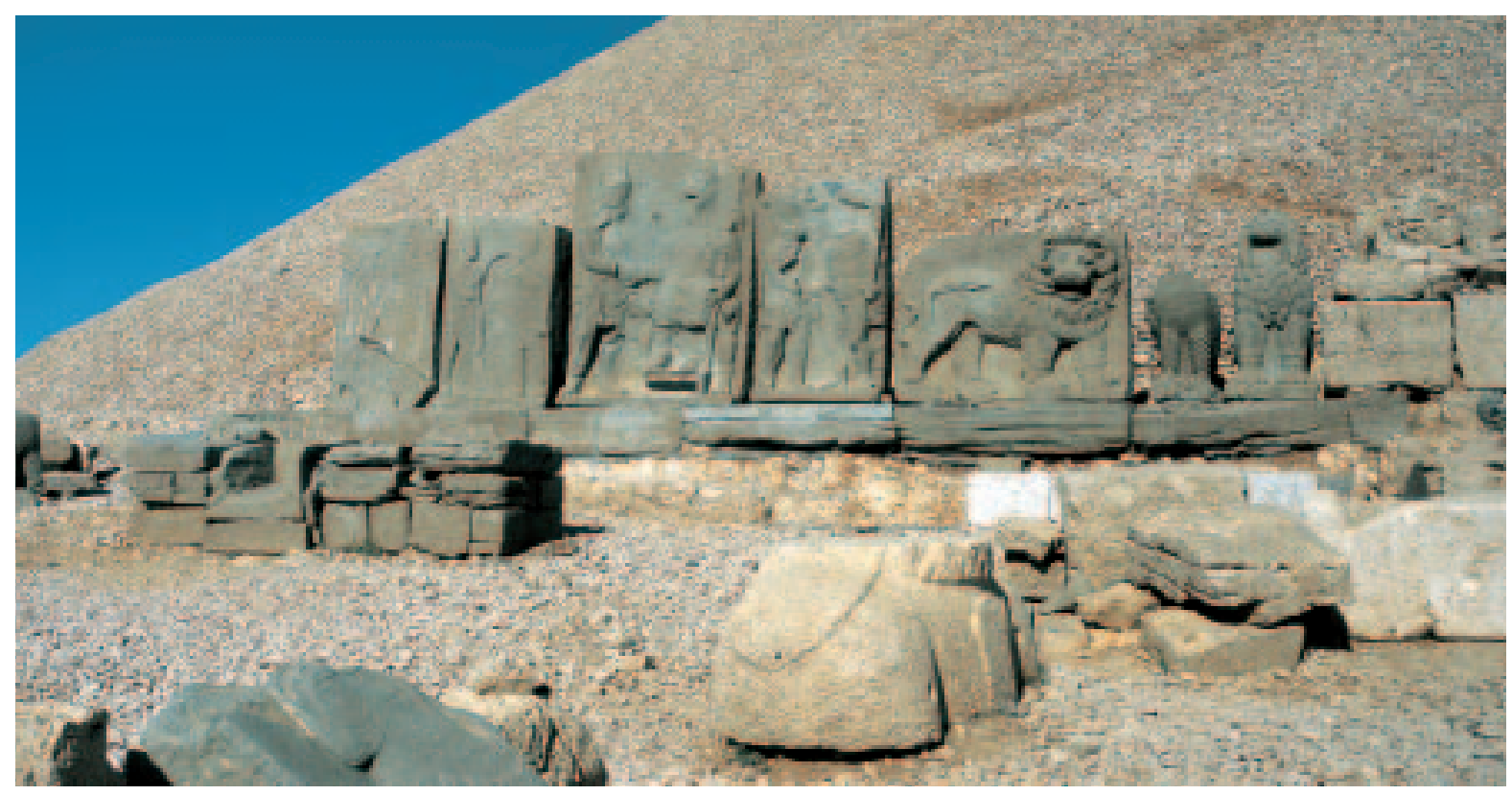

Fig. 20. Nemrud Dăg, West Terrace, the stelae and sculptures next to the colossi (2001, photo E.M. Moormann). 
details of clothing and rendering of the faces. The pathos of the faces is enhanced in the Zeus and Herakles who have a frown in their forehead and bulging flesh over the nose; this feature being shallower on the East Terrace. This and the beards make them look older and more impressive than the youthful Apollo and Antiochos with their smooth roundish cheeks. The back of Kommagene's head is veiled as on the East Terrace. She has remarkably protruding lips, her ears are set (too) high and bear long jewels. The male figures wear the Persian tiara, Antiochos has a feathered one in Armenian fashion. ${ }^{26}$ This headgear consists of a high, almost trapezoidal cap with three long flaps covering the ears and the back. Antiochos' ear-flaps are turned up and arranged over the forehead so that they cover oneanother. ${ }^{27}$ His well-shaped ears are visible. Along the front and the back of the tiaras runs a series of round discs and all are embellished by a diadem tied together on the back, its fillets hanging downwards in the nape. These bands are studded with winged thunderbolts (Antiochos and Zeus) or round and lozenge discs (other males). Antiochos and Zeus have adorned neckbands, the former studded with winged thunderbolts, the latter consisting of a torque ending into two lion heads under the chin (figs. 17-18). ${ }^{28}$

\subsubsection{The stelae and sculptures in tuffit}

As stated, a series of sculptures is placed to the north of the colossi. Their base consists of one tier of limestone and living rock topped by re-used tuffit slabs with erased inscriptions on the surface. ${ }^{29}$ At the southern side one can see how the second layer of the base for the colossal figures covers the tuffit slab (figs. 19-20). The stelae are inserted into this base by means of sockets. Whereas the northern pair of lion and eagle are now set apart, the other pair occupies its original position. ${ }^{30}$ The dimensions of the stelae differ considerably and the set looks rather irregular.

The four northern stelae show a king in Persian attire on the left shaking hands with a deity on the right in the dexiosis ritual. ${ }^{31}$ It is important to see how the king, probably always the same person, adopts iconographic elements of the person in front of him in his own dress and attire - as will become clear from the description given below. ${ }^{32}$ Zeus is much bigger than the king but, because he is sitting their heads are at the same level and heads, hands and other elements have similar sizes. Herakles is a little larger than the king and Apollo is slightly smaller.

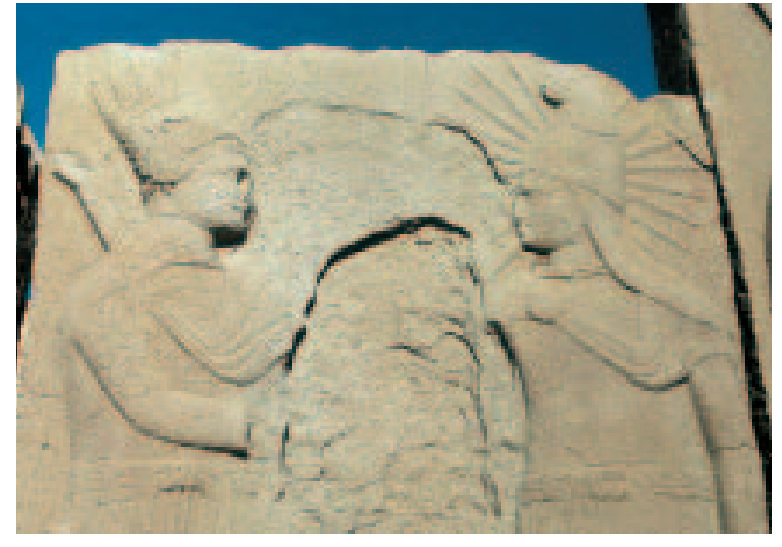

Fig. 21. Nemrud Dă̆, West Terrace, dexiosis stele showing the king and Apollo-Mithras (2001, photo E.M. Moormann).

Nowadays the most northern stele lacks nearly all its relief: on the right the outline of the kalathos and the cornucopia of Kommagene is barely recognizable. Fragments of the figures were found by Humann and Puchstein and carried to Berlin, whereas Goell found the king's head. ${ }^{33}$ The king had his attire adorned with lions and fruits, especially pomegranates.

The second dexiosis stele has the king and Apollo-Mithras who wears a starred Phrygian cap around which a sunburst with sixteen points is shining. The king's tiara has five feathers on top and has a rich adornment of a lion walking to the right in a frame of olive wreath at the lower side and two lions in a lower band. The ear-flap, adorned with olive leaves, is turned up and to the front, the end of the other one is visible underneath. Similar olive leaves are stitched on the king's belt. His face has a round cheek, especially if compared with that of Apollo (fig. 21).

On the third and largest slab Zeus is enthroned on a mighty seat with animal-shaped front legs. The heads of the legs are those of a lion, but with pointed ears and horns. ${ }^{34}$ On top of the back a pair of Greek eagles is seated, with spread wings and heads turned to their master. The tiara of Zeus is adorned with stars and, along the outline, beads. At the lower edge runs a series of thunderbolts. The king's tiara has five feathers on top and the upper part has a thunderbolt and the foliate motive of oak leaves and glands. Underneath there is a diadem with winged thunderbolts. The belt has similar oak leaves and glands, the boots have thunderbolts.

On the fourth stele Herakles holds his leonte and his club near his left flank. Unfortunately 


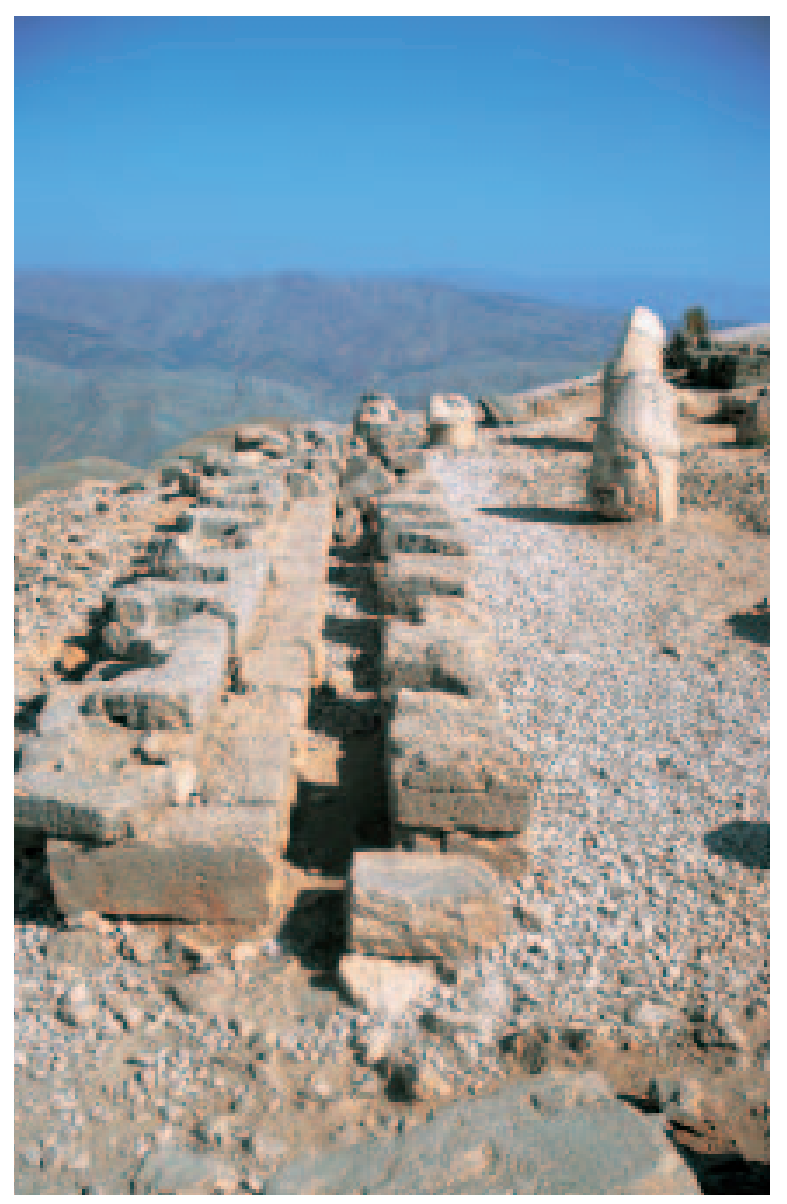

Fig. 22. Nemrud Dă̆, West Terrace, stelae bases and altars, western side (2001, photo E.M. Moormann).

details of the king's dress are worn off, but he must have had a lion and wine leaves as adornment on his dress. ${ }^{35}$

The stele with the Lion horoscope is the most famous piece. The animal strides to the right but turns its head with open muzzle and jutting tongue to the onlooker. A moon crescent covers his chest. Eight-pointed stars are scattered over the surface, three stars with sixteen points (in fact the planets Jupiter, Mercury and Mars) are shining over the back of the animal. They have their names written along the upper edge. We turn to this stele more in detail in section 4.2.2

These stelae look more elaborate and detailed than most of the slabs of the family members, if we assume that state of preservation plays no role. They are made with great skill and knowledge of iconographical details; see for instance the adornments of the various dresses of the kings corresponding with the gods.

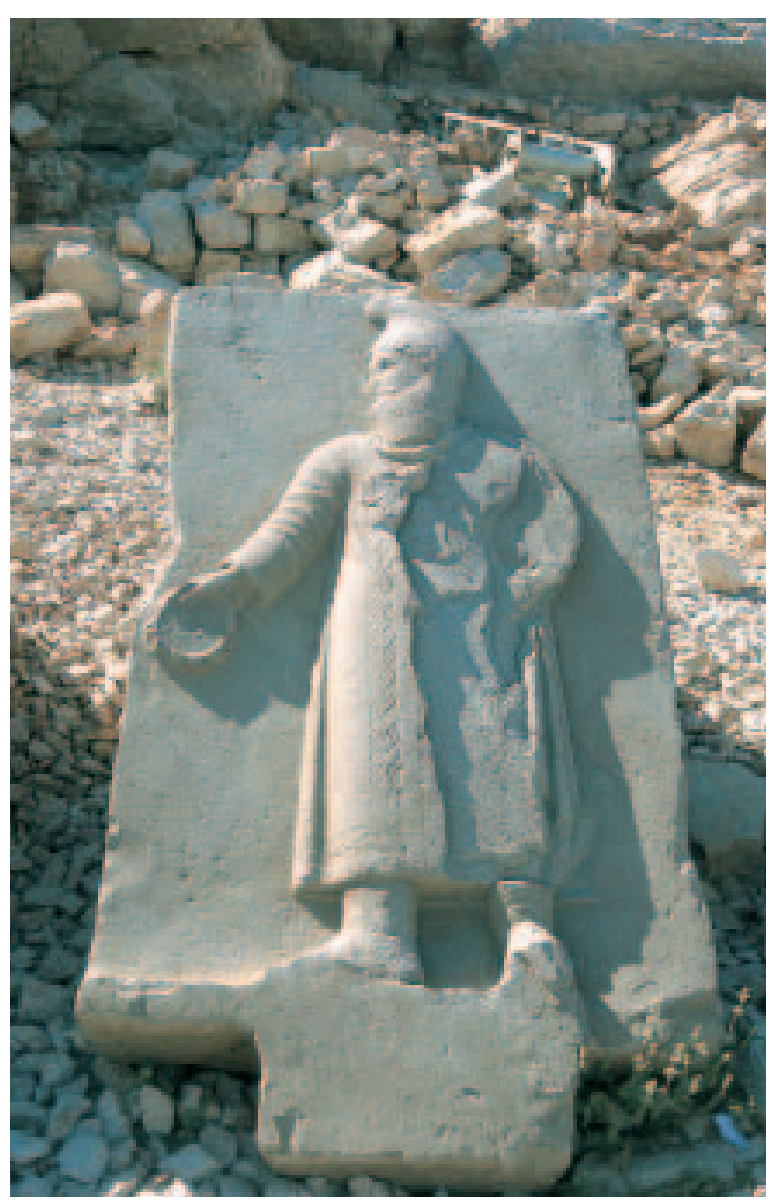

Fig. 23. Nemrud Dă̆, West Terrace, ancestor stele (2001, photo E.M. Moormann).

\subsubsection{Ancestor stelae and altars}

The west row of ancestor stelae and altars nowadays still counts 12 bases for stelae and 12 corresponding altars made from greyish limestone. The blocks that had to contain the stelae rest on a base of large blocks. They can be single or composed of two halves. Behind them, lying on the rock, there are the bases containing sockets for the insertion of the tuffit stelae. Some of them are hewn from the living rock. The altars are composed of two rectangular limestone blocks at the bottom and a square one in the same material on the top. They measure more or less 80-85 (height) x 75 × 75 $\mathrm{cm}$. At the northwest side there are four big tuffit blocks, probably not in original position (fig. 22).

At the southern side of the terrace a similar disposition has been realised as on the western side. Ten bases are still extant, as are 11 of the corresponding altars. As stated above Goell calculated 


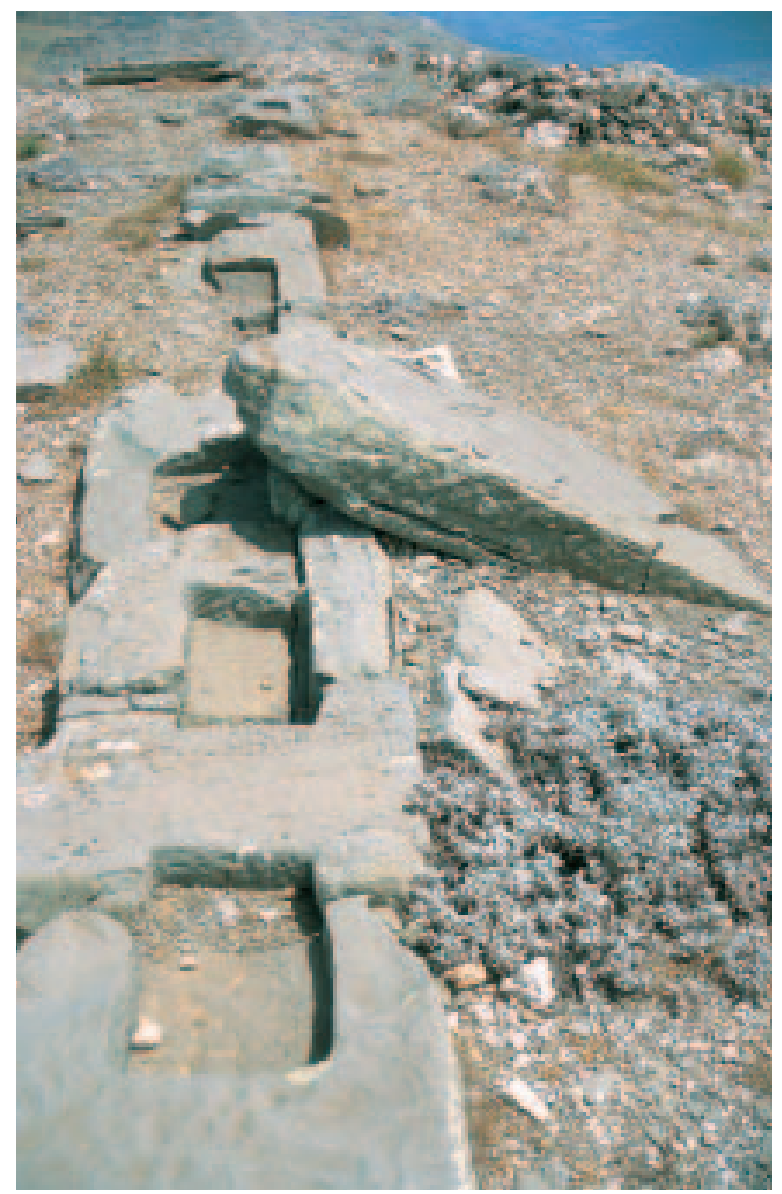

Fig. 24. Nemrud Dă̆g, North Terrace (2001, photo E.M. Moormann).

an original number of 17 sets. In one of the altars the remains of a stele are still visible. The stelae's bases are built up from limestone blocks managed along the edge of the living rock, partly used instead of these blocks (after third block from the east). They measure approximately 60-65 (height) x 70-130 (width) x $85 \mathrm{~cm}$ (depth). The altars, made of tuffit, are less regular than their southern counterparts. Most of them are bigger and contain three layers of blocks and a cover plate on top. All in all, their measurements differ notably. The sixth block from the east has a Greek inscription in four lines on its eastern side. ${ }^{36}$ One may ask whether the difference in format of the altars contrasting to the regularity of all limestone altars on the East and West Terraces - had anything to do with the importance of the person depicted on the corresponding slab. However, such a division cannot be noted on the East Terrace. Besides it seems to have been more difficult to make regu- lar blocks from tuffit than from limestone, as can be seen on the North Terrace.

As a matter of fact we are no longer able to study the slabs: they are nearly all lost. The detailed description by Young remains fundamental (fig. 23). ${ }^{37}$

\subsection{The North Terrace}

At the northern side of the passage between the East Terrace and the West Terrace a series of 42 unworked stelae lies on the ground. They correspond with 57 sockets; there are no altars here. Together, the sockets form a continuous plinth in which two pass-throughs have been made. Puchstein and Humann already observed that the slabs lack reliefs and texts. According to them the stelae had never been erected and they interpreted the overall structure as a kind of fence against the wind. Goell mentioned the find of morter in one of the socket's holes and is of the opinion that the stelae stood upright. In her view the 'wall' was finished (figs. 24-25). ${ }^{38}$

At the north side, near the East Terrace, a rectangular structure in tuffit can be discerned. On this platform stood a large guarding eagle of which only fragments remain. Here, following one of the pass-throughs in the long plinth, a road leads down to the valley. Traces of it can clearly be remarked on the basis of hewings in the rock. Goell already observed a stele lying in the valley below the North Terrace; indeed a logical place for an entrance stele. ${ }^{39}$ Due to the fact that no remains of an inscription are visible on the stele and given the circumstance that it could also derive from the North Terrace, its function remains uncertain.

\subsection{Building materials}

Two sorts of material have been used for the construction of the monument: grey to green slateand sandstone-like stone, called tuffit by the geologist Bernd Fitzner, and white-yellowish limestone. The first material, given its nature generally rather poor and badly preserved, served for making the stelae on all three terraces, some of the smaller freestanding figures and elements of the architecture on the West and East Terraces. It was probably dug in a valley some $1,700 \mathrm{~m}$ from the East Terrace, near the place where recently a hotel has been erected. Here quarry marks can be observed as well as 'Rohlinge'.

The limestone is used for the colossal statues, for most stelae bases and for the altars. It must 
have come from the area itself, but is always thought to differ from that of the mountain itself - very Karstic and splitting easily into plaques. Its origin is so far unknown. 40

The gravel of the tumulus stems from the mountain itself. The rock still standing on the West Terrace may have served as a quarry. ${ }^{41}$

\subsection{Preservation, construction and technique}

All architectonic and sculptural elements are in a bad state of preservation, especially those hewn in the soft tuffit.

\subsubsection{The stelae}

Only some slabs are still erect (as a matter of fact re-erected) and the few lying on the terraces having their original relief are but a small part of the once existing number of slabs. Several sockets show remains of the stelae once erected in it and apparently broken off.

As to the big stelae at the east side of the West Terrace the surface is severely damaged: the Kommagene stele has poor remains only, the other show large lacunae in their reliefs. The corresponding series on the East Terrace is lost apart from tiny fragments found by Goell and stored in the Adiyaman Museum.

\subsubsection{The colossal statues}

On the West Terrace, the nine statues stand up to three of eight tiers; the other blocks tumbled down in several moments, unknown to us. The East Terrace has three of the five figures preserved up to the shoulders (sixth row) and two more or less up to the fifth tier, whilst the animals have fallen off their platform except for the right-hand eagle (three layers on base).

The damages of the heads consist of holes in the surface, which we do not encounter in the other parts of the statues. Therefore it seems that the heads were hewn out of a different material. This is not strange: this way they create an effect similar to that of acroliths, where heads and other nude parts are made of a different sort of marble to create a contrast.

The surfaces no longer show toolmarks apart from some chisel marks in deep-lying places like the corners between the wings and the breasts of the eagles in the fourth and fifth rows. In general, the surfaces are worn by the exposure in the free air. The stone of the statues on the East Terrace is greyish, that of the heads on the Eastern Terrace and of the statues on the West Terrace has a brighter colour and a smoother surface (where not damaged). The material seems different from the limestone of the mountain on this place apart

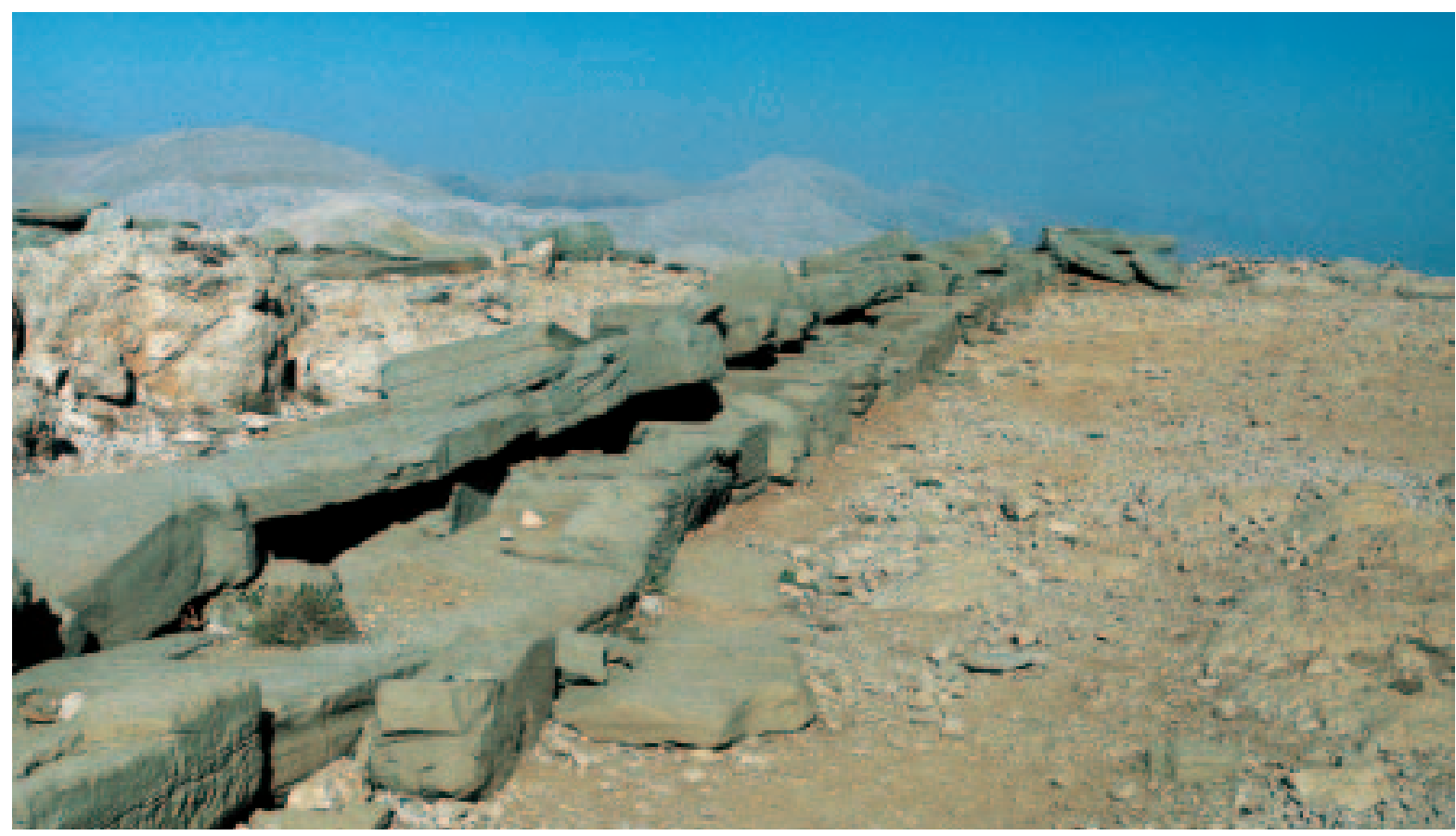

Fig. 25. Nemrud Dă̆, North Terrace (2001, photo E.M. Moormann). 
from the lower elements of the Herakles and the southern pair of animals on the West Terrace which are hewn from the living rock.

The colossal statues are architectonic composites. They stand on a base cut out in the rock and some even have the lower tiers hewn out of that (West Terrace: Herakles, right-side animals). The animals are composed of six tiers, the others in seven (Herakles) or eight (others). The lower layers are like walls of a small building, the interior space being filled with gravel and blocks of limestone. All rows are composed like good masonry by taking into account the joints between bounders and stretchers. The front parts of the lower layers consist of slabs modelled in relief. The upper frontal layers of the figures, from the lap onwards, are plastically rendered and the interior sides have been hollowed out in order to make them more manageable during construction. The shoulders are entirely worked out from single block, as are the heads. No concrete or mortar is used to join the parts; their weight - especially that of the top layers - was enough to keep the blocks in position.

The heads on the East Terrace have protrusions at the bottom and were set into sockets hewn out in the shoulder blocks. The Antiochos head has a pour channel at the bottom ${ }^{42}$ and the shoulder piece of Apollo shows channels near the neck. Zeus has a small channel on top of the tiara element on which the tip had to be placed. The tenon was either made out of the same block as the head (Apollo) or produced separately and set into cavities in both head and shoulder piece (Antiochos, Kommagene). As the tenon of the Apollo $^{43}$ is some five $\mathrm{cm}$ smaller than the cavity, we must assume that this head - and probably the others - after being set into its position, were stabilised by adding lead clamps in the same way architects practiced in constructing buildings with large blocks. The eagles' and the lion's heads and all heads on the West Terrace have flat bottoms corresponding in dimensions to the smooth surfaces on the shoulder pieces. The shoulder piece of the Antiochos has a circle incised. ${ }^{44}$ Therefore, these heads were simply put into position by lifting. Their weight apparently sufficed and the centre of gravity was well calculated.

All blocks of the upper three layers have deep, square holes, varying in number from two to four, with sides of 5-7 cm and 9-12 cm deep (fig. 18). 45 These are never positioned in the bottom or top, but always in the front or the sides and they served to hoist the blocks into their final position. The upper surfaces of most layers have shallow

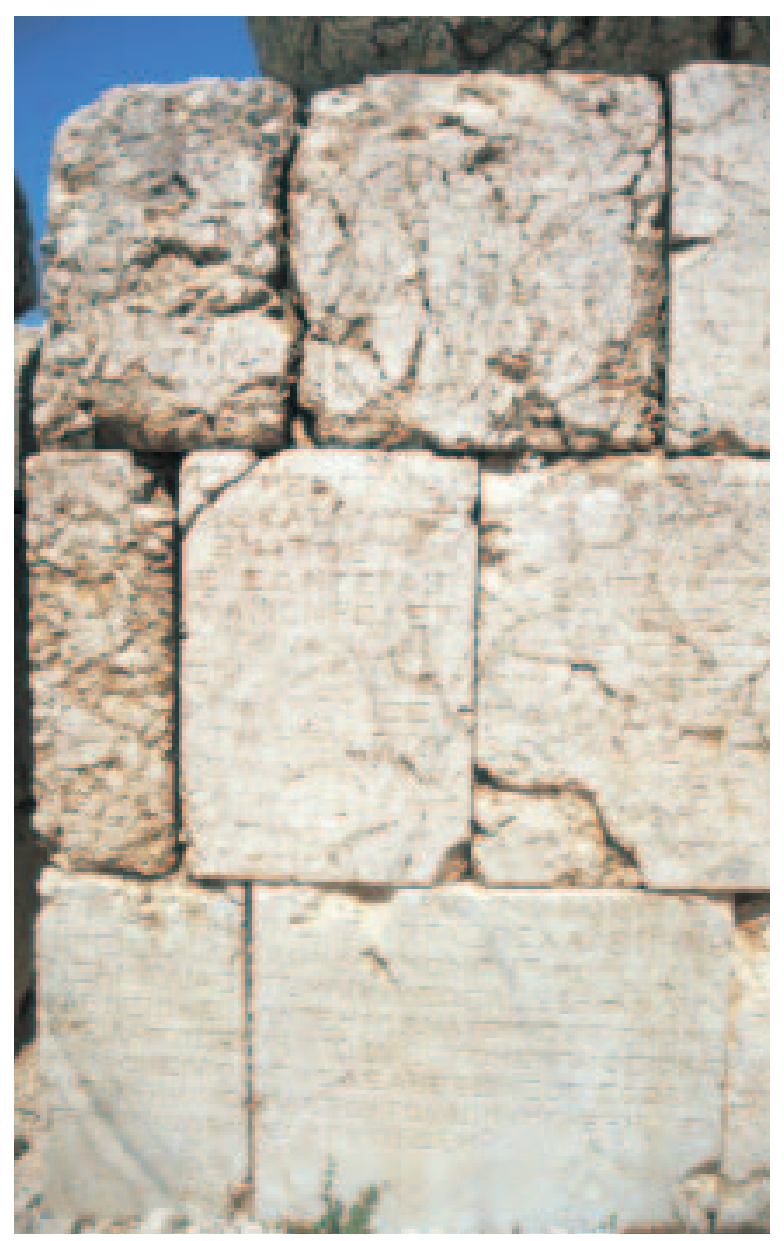

Fig. 26. Nemrud Dăg, East Terrace, the nomos on the back of the colossi (2001, photo E.M. Moormann).

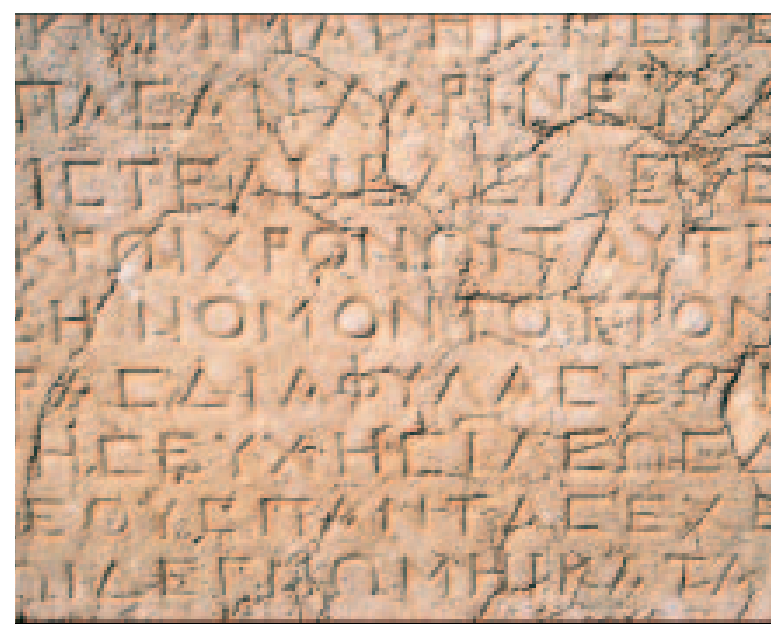

Fig. 27. Nemrud Dăg, West Terrace, the nomos on the back of the colossi (2001, photo E.M. Moormann). 


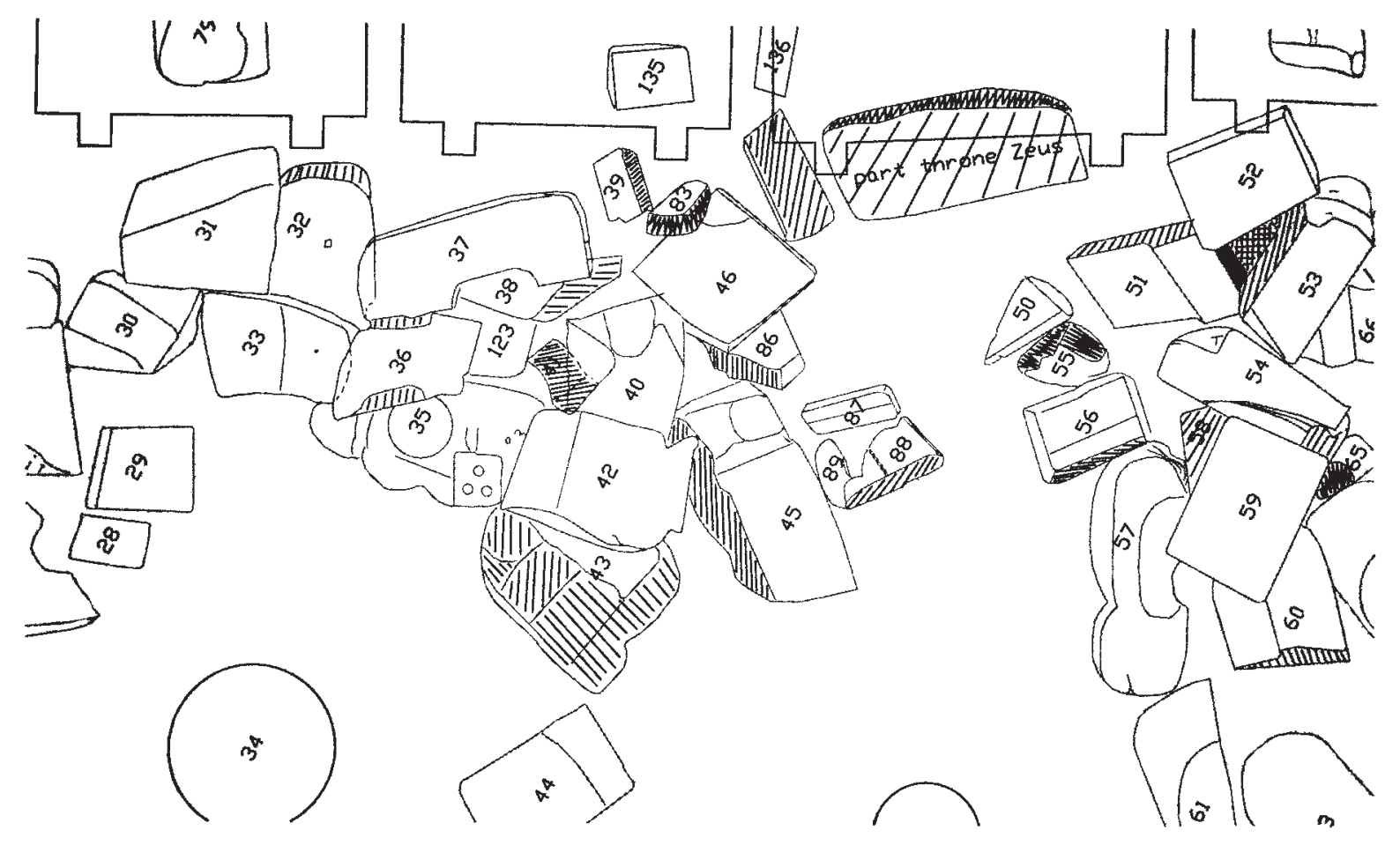

Fig. 28. Nemrud Dă̆, SIS level 2: plan of the West Terrace (@ INF).

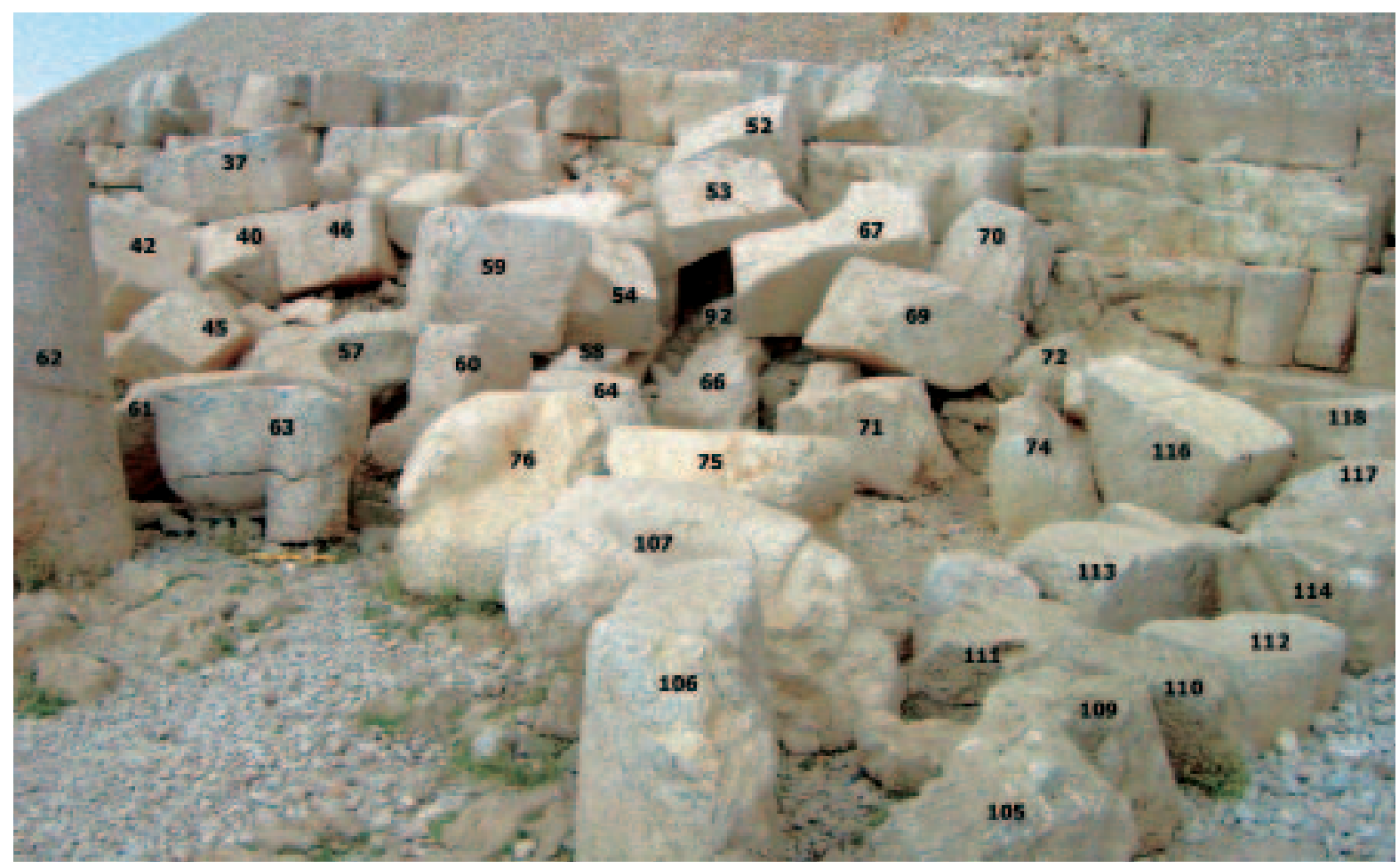

Fig. 29. Nemrud Dă̆g, SIS level 3: overview photograph of the West Terrace (2001, photo T.D. Stek). 
indentations along the edges, probably for managing the blocks in place. As to the heads one may first think of the insertion of elements in metal, but more likely the holes served in all cases to lift the pieces from the earth to their destination. As the more obvious practise of leaving protruding hoisting points in place, only to be finished of after the final placement of blocks, was quite common in the Greek world; in the first instance we might be inclined to think of a re-use, or better re-placement, of the heads already in antiquity, after they had fallen of by, f.i., an earthquake. Be that as it may, the construction of the statues was apparently planned and carried out by an architect, who employed the same methods as were used for the erection of large buildings. The large dimensions of the holes requires filling. In fact, some holes in the columns at Karakuş have been filled in with pieces of worked stone. It is striking, however, that building blocks on other Commagenian sites like Karakuş and Direk Kale also show these holes. Do we have to reckon with the possibility that it was a Kommagenean practise to use lifting holes and leave them just as they are?

One may cautiously consider the possibility that the surfaces of the figures had to be covered with stucco and paint. The harsh climate, however, would make vulnerable this embellishment and work would have to be redone every year.

\subsubsection{The nomos inscription and other texts}

The backs of the human and divine colossi and the relief stelae are inscribed with Greek texts. The colossi bear the nomos inscription, the relief stelae mention Antiochos' ancestors in a standard formula. The lettering on both is carefully executed. There are no guiding lines.

The lay out of the large inscription differs slightly per terrace and some wordings are different as well, but the columns are always the same. They present a sort of sub-chapter; paragraphs are indicated by a long hiatus. The texts on the back of the dexiosis stelae are less well executed (figs. 26-27, 34).

\section{The Amsterdam University Research}

\subsection{The Site Information System (with Tesse D. Stek \& Ellen Thiermann)}

As around $90 \%$ of the blocks with which the statues have been constructed are still at hand, it seems appropriate to reconstruct the colossi on the East and West Terraces. ${ }^{46}$ Therefore, one of this season's main goals was the compilation of a Site Information System. Its goals and use are explained below.

\subsubsection{Goals}

Drawing on the short description of the monument, here presented in section 3, the SIS enables the user to gain further knowledge about in the monument him- or herself. It has different layers or levels, ranging from a general overview to a specific detail.

The most general level (1) is formed by the topographical map (fig. 3). Many thousands of GPS points have been combined and show the tumulus with its remains and some of the characteristic features directly around it. Thus it became clear that the top of Nemrud Dag is not $2150 \mathrm{~m}$. heigh, as always stated, but $2206 \mathrm{~m} .{ }^{47}$

From this overview the user can zoom in on one of the terraces. Level 2 provides detailed maps of the East- and West terraces with the position of the statues, the fallen blocks and most other elements. The level 2 maps consist of a combination of GPS points from the topographical map (level 1) with handmade drawings. A documentation of the actual situation on both terraces had not been done before (fig. 28).

Level 3 takes the user into these maps by overview photographs of the terraces. The terrace's maps can be visualised from different angles while the position of the statues (rather evident) and the location of the different groups of blocks (much more problematic) becomes clearer (fig. 29).

On the fourth level one can look at the colossal statues themselves. Drawings show the statues' structures in different blocks and also indicate which blocks are still in situ.

The statues' tumbled down blocks can be studied on the fifth level. It provides photos of groups of blocks and, after that, of individual blocks. It is combined with a database that shows, i.a., our assignment of the blocks (fig. 30).

Most of the individual blocks can also be found on level 6, in which there are scale drawings of blocks with sculpted details, from different perspectives, thus giving more detailed and precise information than the photographs.

The 3Dimensional reconstruction combines these different levels and will, in general, be of great help in obtaining a general understanding of the monument. For reasons of convenience we thus labelled it level 0 . 
Level 0: 3D reconstruction

Level 1: topographical map

Level 2: terrace plans

Level 3: terrace photographs

Level 4: colossal statues' drawings

Level 5: blocks photographs

Level 6: blocks drawings

\subsubsection{How to use the SIS}

The general structure of the SIS as explained, will be illustrated in this paragraph by a short description of the data now available for the East Terrace and West Terrace.

The East Terrace has been relatively well preserved. The gigantic statues are standing upright for the most part. The eagle and lion are, at both sides, largely collapsed and are less well preserved. Level 0 and 1 provide a general impression of the East Terrace as it is nowadays. On the plan (level 2) the position of the blocks and all other elements are precise, however not all (fragments of) blocks are visible. For the numbering of the blocks see below. ${ }^{48}$ Level 3 are photographs providing an overview of the terrace on which nearly all blocks and other elements can be seen. Blocks are numbered from 1 to 56 (for this numbering see paragraph 4.1.3). Small or unidentifiable fragments are not always included. The database (Blocklist East Terrace) gives our interpretation of the 56 blocks, i.e. where we think they were originally. The statue/layer/block indications refer to the (reconstructed) statues and their structure as presented on level 4 . The statues are named from south to north: A (lion), B (eagle), C (Antiochos), D (Kommagene), E (Zeus), F (Apollo), $\mathrm{G}$ (Herakles), H (eagle), I (lion). The base of the statues is always layer 1; layers are numbered from bottom to top; most statues have 7 layers. If layers consist of different blocks, these have been given a letter. When facing a statue, the block in front, at the left side is designated a; counter clock-wise follow blocks b, c, d and e. The photos of groups of blocks and individual blocks presented in level 5 are also to be consulted together with the database (Blocklist East Terrace). This way the user can study specific parts of the East Terrace, also being able to check our interpretation of the blocks. Level 6, drawings of individual blocks, will be of great help in understanding the features characterising specific blocks. We decided in this stage to provide a relatively large number of drawings of the East Terrace blocks (in comparison to the West Terrace, see below) for practical reasons. The East Terrace blocks can be drawn more easily than those on the West Terrace; besides the structure of the statues can be better understood on the East Terrace because of their better preservation (see further section 4.1.3).

The West Terrace is less well preserved and thus preliminary asked for a different approach. As a general overview of the West Terrace could not be obtained by the laser scans (level 0 and 1 are thus relatively incomplete here), it was decided to compile a plan of the West Terrace based on the (few) GPS points. On these fixed points an imaginary grid was laid down; the blocks were measured and drawn in by hand from this grid. The West Terrace plan presented here (level 2) is thus not $100 \%$ exact, but this hardly matters because the fallen blocks are not in situ. In order to get insight into the present position of parts of statues fallen down it proved to work out very well. For the numbering of the blocks see below. Level 3, overview photographs of the West Terrace, makes the plan understandable. The situation on the West Terrace being more complicated than on the East Terrace, the SIS user finds relatively numerous photographs of it. Blocks are numbered from 1 to 152 , again at random but roughly from north to south. As on the East Terrace, the database (Blocklist West Terrace) gives our interpretation of the 152 blocks. For the statue/layer/block indications, and level 4 in general, the East Terrace statues and their structure necessarely served as a parallel. The same indications are used. In level 5, photographs of the blocks, emphasis was mainly laid on groups of blocks because many times individual blocks do not show many, if any, specific characteristics. Hence, there are for now still many question marks in the database (Blocklist West Terrace). For the same reason, and as explained above, drawings of individual West Terrace blocks (level 6) are few. In general, blocks with a dimension of less than $0.2 \times 0.2 \mathrm{~m}$ have only been included when showing sculpted elements.

In the two blocklists thus seven columns are shown. The blocknumber refers to the number of the block on the plan of the terrace. Then follow the statue/layer/block indications as explained above. Added are the name of the statue and of its part in question; both just for visualisation as this information is already present in the statue/ layer/block indication. The last column indicates the state of preservation, viz. a fragment or a whole block. The blocklists are connected with another part of the database, i.e. the photo/drawinglist. This contains the following information: the code of the photo with the corresponding 


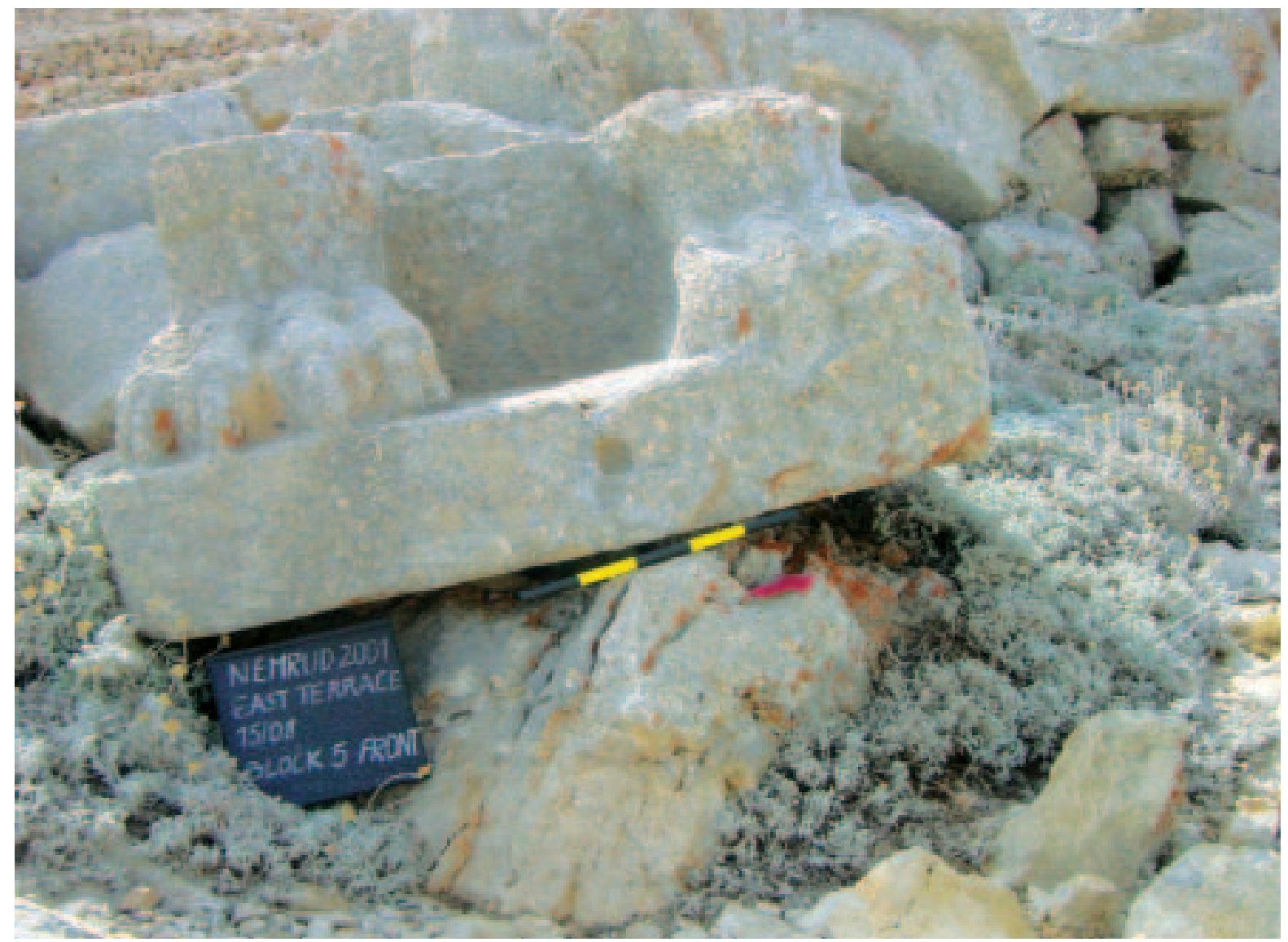

Fig. 30. Nemrud Dă̆g, SIS level 5: block photos of the East Terrace (2001, photo T.D. Stek).

blocknumber; the view (side, detail, overview, etc.); a table indicating if there is a drawing of the block; and remarks. With the photo code the first two letters logically refer to the East Terrace (E) or West Terrace (W), the following figures indicate the blocknummer (in case of overviews the central block has been taken), the final letters indicate the view $(\mathrm{ba}=$ back, $\mathrm{fr}=$ front, $\mathrm{si}=$ side, ls $=$ left side, $\mathrm{rs}=$ right side, $\mathrm{bo}=$ bottom, to $=$ top, gr = group photo, $x x=$ unknown). General overviews, blocks of the statues' bases and the like may have alternative codes; these are however always evident (East Terrace overview 1, West Terrace base F, etc.).

\subsubsection{Block drawings}

As explained above, level 6 of the SIS consists of handmade drawings of the blocks of the colossal statues on the East and West Terrace. For several reasons we aim to document the fallen blocks in detail and as completely as possible.
In the first place the documentation of the status quo of these fragments is necessary before any restoration, conservation or reconstruction work was to be undertaken. Secondly, detailed measurements are needed for our reconstruction proposals, as they can show which blocks fit in and which do not. Details documented by these drawings can also provide further insight into techniques of sculpturing and engineering used; also the lifting holes, for instance, are measured and indicated. And finally, all earlier publications on Nemrud Dağ lack detailed drawings of the tumbled down blocks.

The blocks were given individual numbers which are independent from their possible identification, but generally in correspondence with their present position in the field: from left to right when facing the statues.

Drawings were made from the flat bottom- and top surfaces of the blocks, as these form the junctions with the other tiers of the colossi, and for that reason are indicative of their position in the 
statue. Further drawings document the sculptured side(s) of the blocks. Unfortunately, due to the position of many of the blocks in the field, it was not always possible to provide all three (or more) views. If possible, we reconstructed the outline of damaged or invisible parts of blocks in dotted lines. All drawings were made on a 1:10 scale.

High resolution digital photographs were taken from the same angles as the drawings to add information about texture and colour (level 5). As said above, block drawings and photographs are linked in a database (Blocklist West and East Terrace), where our proposal for the identification is given as well. All drawn blocks are indicated in red on the drawings of the colossi (level 4). During the 2001 campaign the drawings of the blocks lying on the East Terrace were completed. The majority of the blocks on the West Terrace are to be drawn in successive campaigns.

\subsection{Some new observations}

In compiling the SIS, epigraphic and archaeological interpretative research was carried out. The archaeological questions partly raised from the demands mentioned, partly from the preliminary study of the literature available up to now. Some of the questions are dealt with in the following sections.

\subsubsection{Cosmological orientation?}

The monument shows a strong irregularity in the orientation of its elements. No line exactly runs $\mathrm{N}-\mathrm{S}$ or E-W. As to the East Terrace one may observe that Regulus, one of the fixed stars, rises at square angles with the set of colossal statues; their display thus corresponds with Regulus. Therefore, one may assume that the cosmos played a great role in the planning of the various elements, perhaps also including the stelae and their altars. ${ }^{49}$

In general, however, how attractive the possibility of a cosmological orientation may seem, certainly in view of the cosmos' large role in Kommagenian culture and perception in general, we have to remain reticent with these kinds of interpretations. As can be concluded from our short description of the monument, the natural environment, with its possibilities and limitations, played a large role in the monument's building. Always, and perhaps primarily, this kind of practical reasons should be taken into consideration.

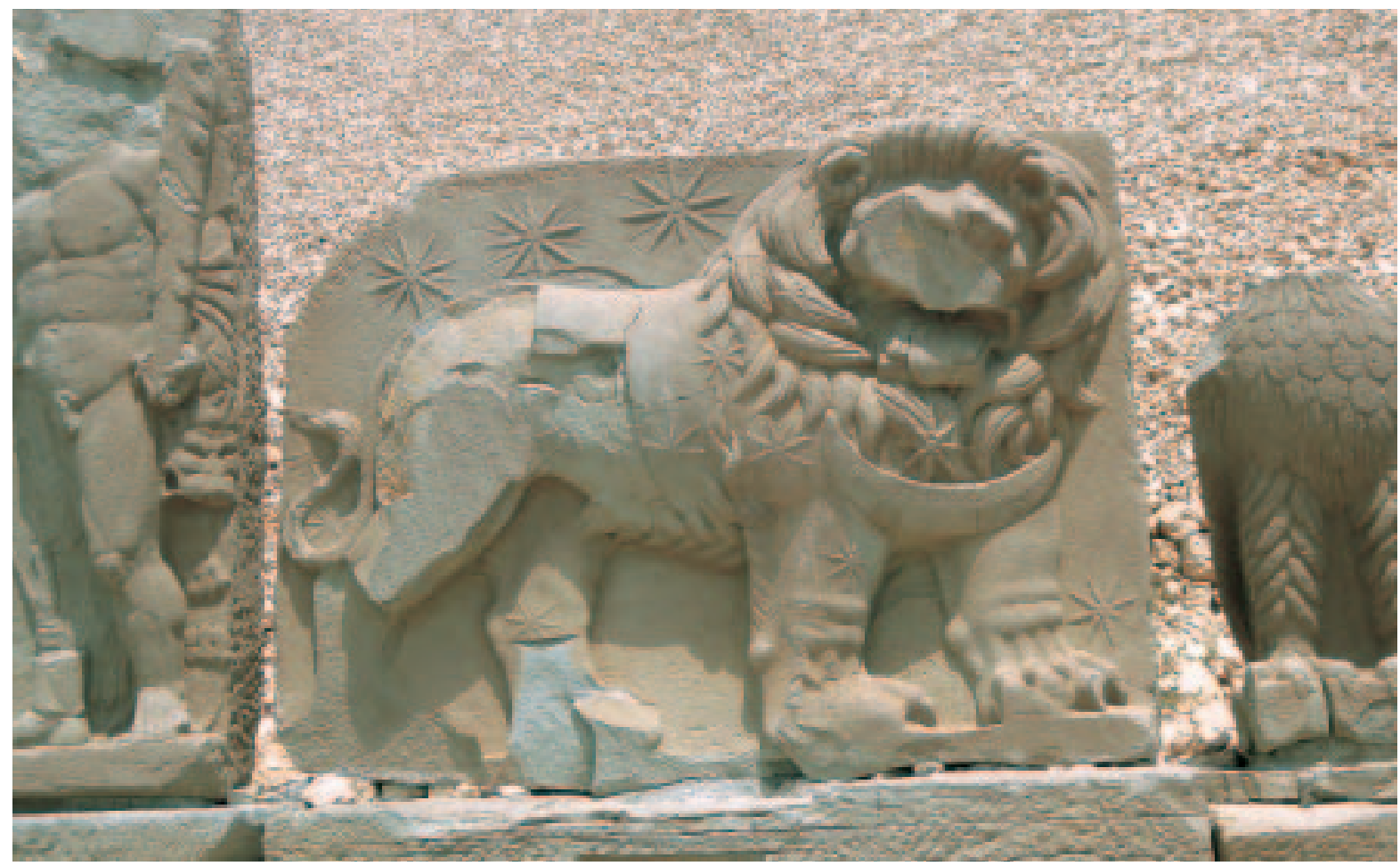

Fig. 31. Nemrud Dă̆g, West Terrace, the Lion horoscope (2001, photo E.M. Moormann). 


\subsubsection{The Lion horoscope: proposal for a new dating (Maurice Crijns)}

One of the most spectacular finds Humann and Puchstein made on the West Terrace was a large slab representing a huge lion, speckled with 19 stars and with a moon crescent on his chest (fig. 31)..$^{50}$ Each star has eight points. Apart from a small difference, the positions of the 19 stars represent the constellation of Lion as described already in antiquity in the Ephemeris of Eratosthenes. ${ }^{51}$

Three larger 'stars' with 16 points are depicted at the upper left edge. They represent the planets Mars, Mercury and Jupiter, as becomes clear from the inscriptions above them.

The two scholars immediately understood that the depiction on the slab represented a horoscope. The stars have a fixed position in the sky. Each evening one can see them at the same place, while the Sun, the Moon and the planets are moving day by day with different velocities. The stele is the frozen picture of the positions of the heavenly bodies at a certain moment at a certain date.

\section{Scholarly opinions: Lehmann and Neugebauer}

Humann and Puchstein consulted the astronomer Paul Lehmann to make a calculation of the date the horoscope would represent. ${ }^{52}$ Lehmann was asked by Karl Humann to take into account the first half of the first century BC only, since Humann assumed that the Lion stele referred to Antiochos. Lehmann found several dates of which the $17^{\text {th }}$ of July 98 BC. seemed most likely. Puchstein thought this date to be the birthday of Antiochos, but, as the inscription states that the $16^{\text {th }}$ of Audnaios (a date in December or January) was the date of birth, he concluded that the calculated date was the day of his conception. Hence, Antiochos should have been born somewhere at the beginning of $97 \mathrm{BC}$ as a seven months child.

This theory has three major problems:

1. the planets Mars, Mercury and Jupiter are standing before Regulus and not, as depicted on the Lion stele, after Regulus;

2. the Moon is not in conjunction with Regulus but has passed Regulus four days before;

3. the Sun is in conjunction with the planets. That means that with Sunset, Mars, Mercury and Jupiter are descending. So these planets cannot be seen at all.

Perhaps as a justification for the imperfect constellation found and the speculative conclusions attached, Puchstein wrote: 'Ein derartiges Reliefbild vermag allerdings nur in sehr allge- meinen Zügen den Zustand des Sternenhimmels zur Zeit des Horoskops wiederzugeben; denn in einer vollkommenen Darstellung desselben müßte sowohl der Teil des Zodiakalzeichens, der bei einer zeitlich bestimmten Beobachtung über dem Horizont emporsteigt, ausdrücklich bezeichnet als auch der gleichzeitige Ort aller Planeten nach Graden oder sonstwie genauer angegeben sein.'53

As Lehmann's constellation could never have been visible in reality, his calculation was generally rejected. In his fundamental work on horoscopes Otto Neugebauer calculated it as the constellation on July 7 of the year 62 BC; a date that could possibly be connected with the coronation of Antiochos. ${ }^{54}$ Neugebauer reconstructed the planetary positions as follows:

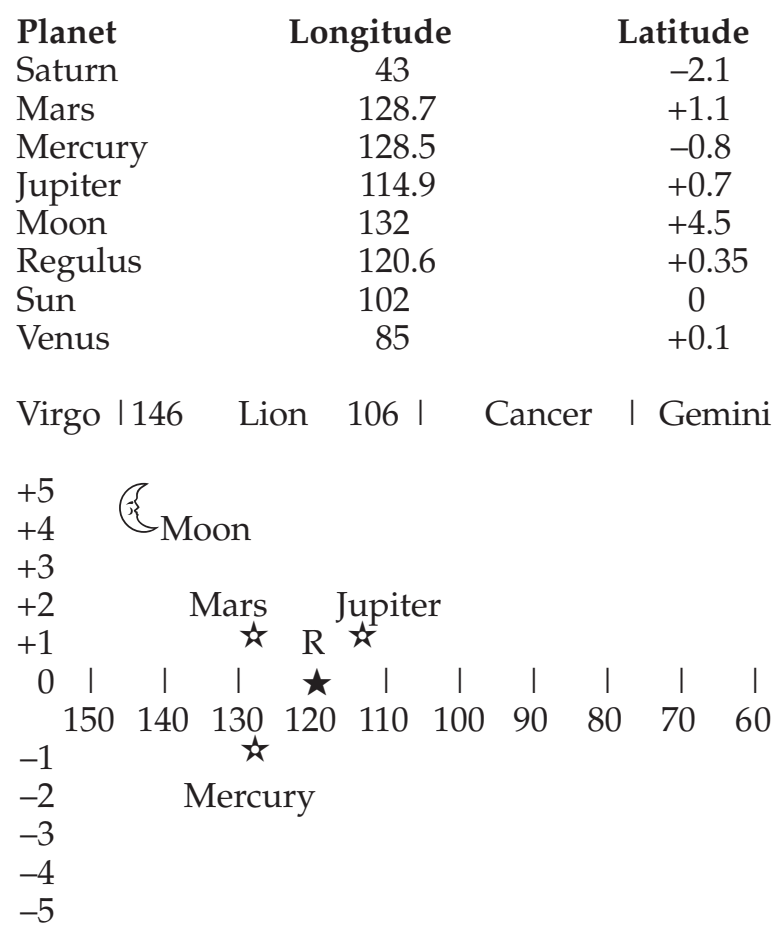

The great advantage of this theory in comparison with the proposal by Lehmann is that all planets including Mercury could be seen during the night. However, the reconstruction of this constellation poses several major problems when we look at the picture on the Lion stele:

1. the Moon has passed Regulus the day before; 2. the Moon has a positive latitude, thus passes Regulus from above and not from below;

3. the Moon has passed all the planets;

4. Mars is in conjunction with Mercury, whereas the stele shows a sequence of Mars-MercuryJupiter; 
5. Jupiter is in front of Regulus and will need another 24 days to pass Regulus.

Goell associated the date found by Neugebauer with the foundation of the hierothesion on Nemrud Dag. ${ }^{55}$ Wolfgang Haase saw the stele as the expression of a personal katasterismos of the king. 56

\section{A new calculation}

We can conclude that from all hypothetical constellations between 100 and $50 \mathrm{BC}$, this one equals most that of the Lion horoscope, but that it is not identical and thus remains unsatisfactory. Therefore, a reinvestigation has been executed, in which the assumption that the constellation has to be searched in the era between 100 and $50 \mathrm{BC}$ has been abandoned. Starting from 1 AD backwards a search was executed, making use of the Ephemeris of Tuckerman. ${ }^{57}$

Jupiter needs about 12 years to pass the ecliptica (i.e. the, in fact imaginary, circle in the sky the sun seems to pass through within a year), Mars 2 years and Mercury 1 year. The Moon passes the ecliptica in 1 month. First, those periods were selected in which Jupiter was in the constellation of Lion as depicted on the stele, according to Humann and Puchstein ranging from 106 to 146 degrees of the ecliptica. From these periods those were singled out in which Mars was also moving through this part of the ecliptica. And the same had to be true for Mercury. The second selection criterion was the sequence of these planets according to the Lion stele: Mars-Mercury-Jupiter. As a result the constellation of the July 14, 109 BC (Julian calendar) was found. 58

The following planetary positions are derived from the Tuckerman Ephemeris by a linear interpolation for 19h00 Babylonian Time, being 18h34 Local Time at Nemrud Dağ (co-ordinates 37 $59^{\prime}$ $\mathrm{N}$ and $38^{\circ} 45^{\prime} \mathrm{E}$ ).

$\begin{array}{lrr}\text { Planet } & \text { Longitude } & \text { Latitude } \\ \text { Saturn } & 184.06 & +2.31 \\ \text { Mars } & 135.24 & +1.09 \\ \text { Mercury } & 133.21 & -0.6 \\ \text { Jupiter } & 126.38 & +0.93 \\ \text { Moon } & 119.82 & -4.52 \\ \text { Regulus } & 120.6 & +0.35 \\ \text { Sun } & 108.38 & 0 \\ \text { Venus } & 102.49 & -6.79\end{array}$

The Moon is not corrected for parallax. To an observer on the surface of the earth, the position of a body at a finite distance will generally differ from its geocentric position, owing to the observer's location off the line from the centre of the Earth to the body. This effect is called parallax and occurs especially in case of the Moon.

The following picture shows the sky seen from the West on the evening of the 14th of July 109 BC:

$$
\begin{aligned}
& \text { Virgo |146 Lion } 106 \text { | Cancer | Gemini } \\
& +5 \\
& +4 \\
& +3 \\
& +2 \\
& +1
\end{aligned}
$$

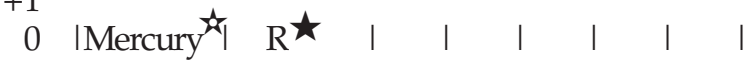

$$
\begin{aligned}
& \begin{array}{llllllllll}
150 & 140 & 130 & 120 & 110 & 100 & 90 & 80 & 70 & 60
\end{array} \\
& -1 \\
& -2 \\
& -3 \\
& -4 \\
& -5
\end{aligned}
$$

As to the visibility of the planets the distance to the Sun is of importance as well as the brightness (magnitude). Jean Meeus was so kind to calculate following magnitudes:

$\begin{array}{lrrrr}\text { Planet } & \text { Mars Mercury } & \text { Jupiter } & \text { Regulus } \\ \text { Magnitude } & +2.0 & +0.2 & -1.3 & +1.3\end{array}$

- Mars could be seen with the naked eye.

- Mercury cannot be seen with the naked eye most of the time. However, on this particular day Mercury had reached almost its maximum distance from the Sun (being 28 degrees) and was therefore well visible with a magnitude of +0.2 .

- Jupiter with a magnitude of -1.3 had the greatest brightness and could be seen as a big dot in the sky.

- Venus had set before the Sun and could not been seen.

- Saturn could be seen very well. However, he stood far away from the other planets, close to the south at its culmination.

\section{The welcoming of the gods}

To summarise our hypothesis: the weeks before the planets had passed one after another Regulus: Jupiter on June 10, Mars on June 21, Mercury on the July 6 and finally the Moon on the evening of July $14 .{ }^{59}$ Interestingly, the planets Jupiter, Mars and Mercury (the gods) passed Regulus (the king) from above, whereas the Moon (the land of 
Kommagene) passed from below. For the people of Kommagene it must have looked as if the gods Zeus/Oromasdes (Jupiter), Artagnes/Herakles/ Ares (Mars), Apollo/Mithras/Helios/Hermes (Mercury) and Kommagene (Moon), had come one after another to congratulate Regulus, the King.

The welcoming of the gods is (also) depicted on the four dexiosis stelae at the left of the Lion stele (see paragraph 3.2.3). Furthermore the $10^{\text {th }}$ of Loos (i.e. July 14) is mentioned in the inscription as the date of the coronation of the king.

The exact time of the constellation was Sunset, 19h20 Local Real Time (=16h45 UT). To calculate this time in greater detail, calculations are required by linear interpolation based on the Tuckerman Ephemeris. We could make use of the astronomical software developed by Jan Rademaker to do this. The planets' positions can be reconstructed as follows:

$\begin{array}{lrr}\text { Planet } & \text { Longitude } & \text { Latitude } \\ \text { Mars } & 135.24 & +1.08 \\ \text { Mercury } & 133.33 & +0.06 \\ \text { Jupiter } & 126.37 & +0.93 \\ \text { Moon } & 120.13 & -5.72 \\ \text { Regulus } & 120.60 & +0.35 \\ \text { Sun } & 108.40 & 0\end{array}$

Seen from Mount Nemrud the positions are as follows:

$\begin{array}{lrr}\text { Planet } & \text { Azimuth } & \text { Height } \\ \text { Mars } & 98.93 & +17.33 \\ \text { Mercury } & 99.87 & +15.37 \\ \text { Jupiter } & 106.05 & +11.75 \\ \text { Moon } & 106.70 & +2.65 \\ \text { Regulus } & 110.22 & +7.63 \\ \text { Sun } & 119.37 & 0.45^{3}\end{array}$

1 The position of the Moon has been corrected for parallax.

2 Azimuth: South 0 degrees, West 90 degrees, etc. Height: 0 degrees $=$ horizon.

3 The visible Sunset and Sunrise is influenced by the bending of the light beams by the atmosphere. This phenomenon is called atmospheric defraction. The Sun is lifted approximately + 0.5 degree at sea level and approximately 0.4 degree at an altitude of 2,000 $\mathrm{m}$. So, the visible Sunset seen by an observer at Nemrud Dağ occurs when the Sun is approximately 0.4 degree below the horizon. Sunset is therefore 19h20 Local Real Time with a possible deviation of maximum 2 minutes.
Regulus was to be seen in the evening sky, but it is not sure that the conjunction of Moon and Regulus was visible, although 24 hours had passed after New Moon. The time lapse between Sunset and the descent of the Moon was about 17 minutes. If the Moon-Regulus conjunction was visible from the top of the mountain, it was only for a very short time: just before the descent of the Moon at 19h37 Local Real Time. In the minutes before, the complete constellation as depicted on the Lion horoscope, was in place. Next, the constellation disappeared from the sky part by part; Regulus descended at 20h04, Jupiter at 20h25, Mercury at 20h43 and Mars at 20h53.

This particular phenomenon makes it possible to determine not only the date but also the time of the constellation, viz. 109 BC, July $14^{\text {th }}$, at approximately 19h35 Local Real Time.

\section{The originator of the Lion horoscope}

It has been assumed that Antiochos erected the Lion stele in the first half of the $1^{\text {st }}$ century BC. Humann and Puchstein expressed their doubts about the dating of the stele because of the clumsy style: 'An einem etwa um das Jahr 40 v. Chr. entstandenen Werk von hellenistischer Hand würde man Eigenschaften wie die eben geschilderten gewiß nicht erwarten. ${ }^{60}$ A dating to 109 B.C. perhaps could explain why the stylistic features differ so much. Some scholars proposed that there has been an earlier sanctuary on top of Nemrud Dağ constructed by Mithradates I Kallinikos, the father of Antiochos. The dating of the Lion horoscope provides us a new clue to corroborate this hypothesis (see also section 4.2.3).

\subsubsection{Chronology: a new dating frame?}

In all extant publications on Nemrud Dağ the monument is considered a work ordered by one single man, commemorating the glory of himself and, in the second place, that of his ancestors: Antiochos I. This king reigned over the small state of Kommagene from 69 to $36 \mathrm{BC}^{61}$ and, as stated in his inscription, he erected the statues of Zeus, Kommagene, Apollo, Herakles and himself when he was old of age. ${ }^{62}$ His father makes part of the 'Ahnengalerie' and his son Mithradates II is mentioned as one of the young persons on the slabs. Some scholars suggest that the monument was never finished.63 The Antiochos' head on the East Terrace with not worked-out ears and the absence of any find of ceramics and other mobilia were the main arguments. 
The evidence of the Lion horoscope and the (possible) presence of a second horoscope in the shape of the colossi (see 4.2.7) raise the question whether we have to reckon with the possibility of two different monuments. Humann and Puchstein already observed the difference in style between the stelae and the statues. A remarkable feature in this respect is the use of two different materials: tuffit for the stelae and part of the altars and building elements and limestone for the colossal statues and greater part of the altars and the slabs' bases.

Because of difference of material and differences in form and style of the stelae in respect to the limestone statues one may suspect that the tuffit elements form an independent ensemble, not made in combination with the statues. If they are considered separate from the statues they seem older and may belong to the reign of Mithradates I: the (new) date of the horoscope is the main clue for this conclusion. Besides, the inscriptions of Antiochos on the back-sides of the dexiosis stelae on the West Terrace are written over erased older texts, which have left an irregular striated, not smooth surface (fig. 34). ${ }^{64}$ It cannot be established whether the date on the Lion horoscope is also the date of production.

In view of the new date, one should consider the possibility that Mithradates had himself erected a monument on the mountain in 109 BC, or soon after. Alternatively, Antiochos may have transferred a monument that his father had already built elsewhere, to this barren spot.

Points of consideration are:

1. the two different constructing materials, tuffit and limestone;

2. the traces of erased inscriptions on the stelae and their bases next to the statues on the West Terrace;

3. the date of $109 \mathrm{BC}$ indicated in the Lion horoscope;

4. construction details;

5. the statues are mentioned in Antiochos' large text, but that the slabs are not.

Considering this, we suggest that the monument was not planned and executed at one single moment in time, but was executed in several stages. As a working hypothesis we propose the following chronological framework.

'Tuffit phase': Mithradates I constructed a terrace on the East Terrace on which he erected a series of stelae, and built a base with stelae on the West Terrace. The stelae of the ancestors and himself as the last member of the family were placed in a display we cannot reconstruct apart from the few tuffit bases at the southern side of the East Terrace. All tuffit elements, including guardians in the shape of threedimensional lions and eagles, were erected on Nemrud Dağ in this period. This work must have been carried out at an indeterminable moment during the reign of Mithradates I, viz. 109-69 BC. The series of stelae on the North Terrace were erected, but not worked with texts or reliefs.

'Limestone phase': Antiochos enlarged the monument, turning it into his tomb. He constructed the artificial tumulus, hewed out a terrace over the old one on the East Terrace and enlarged the space on the West Terrace by cutting out the stone until the part still rising at the south side. The addition of the gigantic statues on the West Terrace created a new situation for the old stelae. These had to be re-placed into new bases, located in a position fitting to the new setting and therefore the row along the west side was created. The series on the south side probably held their original position and kept the old altars in tuffit. The rows on the East Terrace were restored: old blocks are visible under the northern row (fig. 19). 65 Antiochos erased the old text of Mithradates I on the dexiosis stelae - it could have been a nomos according to Waldmann and Goell - and wrote his own texts on them in a rather clumsy style (especially if compared to the nomos on the backs of the colossi). This gigantic work was not completed as we can see in various parts of the colossal statues (heads of Apollo and Antiochos on East Terrace, lack of holes for heads in neck pieces on West Terrace). As the king states in the large text that he was old, we must assume that the work began in his late years, let's say the last decade of his reign (45-36 BC). 66

'Aftermath': Mithradates II ascended the throne after a struggle with his brother. He apparently had not been the first candidate. He left Nemrud Dağ as it was and started work on a new tomb at Karakuş, where his mother Isias (maybe Isias Philostorgos), his sister Antiochis and her daughter Aka would be buried. ${ }^{67}$ His respect for his father had perhaps shrunk after the problems about the succession. Sanders even suggests that Antiochos was murdered. ${ }^{68}$ Another reason may be the diminished prestige of the Kommagene kingdom; or a combination of either. ${ }^{69}$

Also other scholars working on the mountain already hinted at a more extensive chronological framework. Already Waldmann stated that there was perhaps an earlier sanctuary, built by Mithridates I, as did Şahin. ${ }^{70}$ Goell had an elaborated hypothesis on an earlier sanctuary and 
Jacobs and Hoepfner talk in a general vein about 'eine frühere Planungsphase'. ${ }^{71}$

It may be best to reserve judgment on this hypothesis at this stage of our research. In the first instance the presence of two different kinds of material may well be explained on practical grounds alone: hard stone was used for the statues, whereas the softer limestone was easier to work on for the reliefs. One also has to count with the possibility that the Lion horoscope, representing - as we have argued - a date in 109 BC, was made later on to commemorate an important historical event. Lastly the interpretations by Hoepfner have to be noted in this respect. In the end this author considers Antiochos' building activities as a 'Kunst-Mythos' and notes that the German excavations in Arsameia have never succeeded in finding the older phases that Antiochos claimed in his texts: 'Und wer unter den Reliefbildern ältere Stücke ausmachen möchte, entspricht zwar den Erwartungen des Königs, befindet sich aber wahrscheinlich auf dem Holzweg. ${ }^{\prime 72}$ The scholar looking for different phases in Antiochos' building program is therefore warned.

\subsubsection{The lower ensemble on the East Terrace}

Goell found numerous mostly tiny remains of stelae at the foot of the huge statues on a sort of podium over a flight of what she thought to be three steps. She reconstructed a row of stelae similar to that still standing on the West Terrace but could not establish their sequence. Other stelae may depict a coronation ceremony (see paragraph 3.1.3).

This unit forms an ensemble on its own and nowadays has a low flight of steps in tuffit at the right and left hand sides. Goell interpreted these as steps leading to the higher terrace with the colossal statues. But from observations on site it has become clear that Goell's interpretation should probably be rejected. These steps, irregular though they are, belong to the construction of the lower terrace. ${ }^{73}$

Goell's reconstruction of five stelae standing on this structure, four of which with a dexiosis and one with a Lion horoscope, the same as on the West Terrace, is generally accepted. ${ }^{74}$ It is important to realise, however, that this reconstruction is only based on the find of some tiny relief fragments. Some of these indeed seem to be part of a horoscope; the other possibly belonged to dexiosis stelae. ${ }^{75}$ Goell's text seems to suggest that also part of the stele of the lion was found; but she presents no evidence in support of this, nor does she produce material evidence for the flanking lion and eagle statues. We must conclude, then, that we should approach Goell's conclusions with care. We can conclude that there may have been a horoscope stele on the East Terrace, and that it stood with some undetermined stelae on the podium structure. In view of the structural similarities between the East and West terraces, Goell's reconstruction is in itself not unreasonable, but it should be remembered that we cannot determine the exact nature and sequence of these stelae.

On the basis of our hypothetical chronological framework formulated above, one may cautiously propose the following sequence of situations. Mithradates I created the East Terrace with a plateau cut out in the mountain. He erected slabs with representations of himself in the act of dexiosis with Zeus, Kommagene, Apollo and Herakles as well as the Lion horoscope and the coronation stelae. In front of it the stepped structure was constructed. Its purpose cannot be determined: was it an altar, a podium or something else? (see further below, section 4.2.5). The other sides of the terrace were flanked by the series of ancestors, the 15 Persians at the north side, the 17 Greeks at the south side.

Mithradates' son Antiochos left the old situation more or less intact, but replaced the fragile bases of the stelae by limestone blocks. More important is his amplification of the ensemble: he cut out a second terrace over the niche built by his father and placed here the series of nine colossal statues. The old ceremonies may have continued in the old form and be enriched by special elements regarding his own monument. It is not yet entirely clear how the ancient visitors approached these new colossi. Their platform has three steps in front and some more at the side of the northern eagle. Here one could expect a prolongation of the flight of stairs built by Mithradates I as suggested by Goell, but it seems that this would have been simply too high for stairs of this type. Maybe, something like the modern ramp that was built at the north side, also existed in antiquity, which may have provided a connection between the North and West Terraces. It is unclear whether there were stairs at the southern side, the place where people entered the terrace via the twisting staircase.

Antiochos embraced, as it were, his father's monument by building over it his own series of statues. Their upper outline reflected at the same moment the contour of the tumulus built by him over the mountain itself. Whereas Mithradates I sought contact with the gods by means of dexiosis, Antiochos placed himself at the same level as the gods. 


\subsubsection{The 'Fire Altar' on the East Terrace: true or false?}

Humann and Puchstein found two parallel rows of steps running east-west at the eastern edge of the East Terrace, five steps at the south and four on the north, together with a wall running northsouth east of these steps and a 'dromos' directed towards the statues. ${ }^{76}$ This situation is also depicted on Hamdi Bey's map. Goell, on the basis of information of her workers, thought the 'dromos' to be a modern construction, a sort of bait for catching kekliks, a local sort of pheasant, and destroyed it. 77 The other remains were reconstructed as three of four sides of a large stepped altar. As such the reconstruction of the stepped elements and the retaining wall into a square architectonical structure (fig. 4) is not unreasonable. The old maps suggest a straight outline at the west side of the steps. Most recently, Hoepfner did agree with this reconstruction and considered the altar as an essential part of the sanctuary. ${ }^{78}$

However, this reconstruction does not immediately allow an interpretation of the platform as an altar. The shape of the monument and the notion of a stepped element at one side of the terrace can be explained in various ways. One could, for instance, imagine the king himself, with local dignitaries around him, sitting under a kind of velum, diametrically opposed to the figure of Zeus, looking at ceremonies in the courtyard.

We suppose to treat the structure destroyed by Goell as an original element for the following reasons:

1. the 'bait' has regular, smooth inner walls and rough outer ones according to the very accurate map by Humann and Puchstein (Hamdi Bey only has straight lines);

2. the walls stand at square angles to the 'altar';

3 . the structure points exactly towards the colossal statue of Apollo and is not positioned in the middle of the 'altar' wall.

Utecht's geophysical research evidenced the presence of a cavity under the 'altar' ${ }^{79}$ One may, therefore, ask whether the parallel walls formed a sort of dromos leading towards the hollow rooms under the terrace. That does not mean that we suggest the presence of the tomb chamber here: the cavities seem to be too small, but one may think of an offering place. Its nature can only be investigated if Goell's altar will be demolished.

In conclusion, we fear that Goell's decision was incorrect. The destruction of the evidence makes a check impossible. The idea of an altar may well have been inspired by a - not written - comparison with the Zeus altar at Pergamon or other monumental examples of this era. ${ }^{80}$

\subsubsection{The West Terrace in its oldest shape}

In this case our hypothesis concerning the phases of construction, does not help us any further in determining how the old situation differed from the new. At one glance, it is clear how the tuffit base of the stelae at the right side is covered by the base of the statues. The steps cut from the living rock under the lower layer of the colossi reach a slightly higher level than the steps under the stelae (fig. 19). ${ }^{81}$ This implicates an alteration or an adaptation to a new situation.

The juxtaposition of the couples of lion and eagle in both tuffit and limestone can possibly be explained as a sign of philia, piety on the part of Antiochos towards his father: he wanted to keep complete the old monument. In a way, even the juxtaposition of the same gods in two forms (enthroned and in the act of dexiosis) is - to say the least - odd.

As said in the description (section 3.2.3; fig. 20), the series seems to be irregular because of the different measurements that were used, and because of the carefully rounded outlines of the top that rarely correspond to the adjacent slabs. The Kommagene and Apollo stelae seem to form a couple; their upper outlines form a shallow curve. The other slabs have similar curved tops, but do not match. If we were to take into account the possibility that there used to be counterparts, we would have to assume at least two other pairs of gods, one matching the Zeus stele, and one matching the Herakles stele. The Lion horoscope, with its rounded left upper corner where the inscription follows the outline, may have had its own counterpart as well, for instance the constellation Eagle (Scorpion/Aquarius).

If we are right in distinguishing a construction in two stages, we are, however, unable at present to reconstruct the first phase. Antiochos apparently had to change the entire area when he wanted to add the colossal figures on this narrow place. The unsatisfactory placement of a row of ancestor stelae along the western side can have been the only solution available.

\subsubsection{The sequence of the colossal statues}

It has been a matter of scholarly debate where the Apollo and Antiochos heads have to be 
located. Humann and Puchstein meant that the king had his seat between Zeus and Herakles; they only knew the unbearded head nowadays still standing in front of the terrace (fig. 11) and had not yet discovered the other one lying at the backside of the colossi. ${ }^{82}$ This hypothesis was discarded by Goell and since the important essay by John H. Young (1964) it is generally assumed that Antiochos is the figure sitting at the extreme left. ${ }^{83}$ Young's main argument is the iconography of the Armenian tiara with the upturned flaps. He also points at the order of the figures as mentioned in the inscription (East Terrace IIa, 9-17): apparently the king started from the main figure, Zeus, listed the figures to the right (Herakles is sure) and concluded with those on the left. There are some additional arguments in favour of Young's proposal:

1. the actual position of the heads of Apollo and Antiochos; 84

2. Antiochos forms a parallel to the semi-god Herakles in sharing the gods' community and 'adds' himself to them;

3. the usual position of a ktistes;

4. the height of the statues in relation to one another.

The choice of these particular gods is not explicitly explained apart from that of Kommagene as the symbol of his patris pantrophos. The choice for Zeus-Oromasdes, the father and leader of the gods, is obvious and Artagnes-Herakles-Ares apparently serves as a role model for Hellenistic kings (see infra). The association to Ares is perhaps due to an important victory like that at Pharsalos in 48 BC. 85 This does not seem very likely, however, in view of the fact that nowhere in the complex a direct hint at contemporary politics can be found, as well as the circumstance that dynastic presentation, and not self-representation seems to come to the fore most dominantly on Nemrud Dağ.

There is no specific reason known for the insertion of Apollo-Mithras-Helios-Hermes. We propose two more hidden explanations, an astrological and a symbolical one. ${ }^{86}$

The first idea, originally put forward by $\mathrm{M}$. Crijns, brings us back to astrology and astronomy. All figures seem to symbolise a star in the constellation and the series may thus form a specific situation like that in the Lion horoscope:

$\begin{array}{lll}\text { Statue } & = & \text { heavenly body } \\ \text { Lion } & = & \text { Lion }\end{array}$

$\begin{array}{lll}\text { Eagle } & = & \text { Scorpion/Aquarius } \\ \text { Kommagene } & = & \text { Moon } \\ \text { Zeus } & = & \text { Jupiter } \\ \text { Apollo } & = & \text { Mercury } \\ \text { Herakles } & = & \text { Mars } \\ \text { Eagle } & = & \text { Scorpion/Aquarius } \\ \text { Lion } & = & \text { Lion }\end{array}$

The gods seem to look towards their own stars. Mercury is only visible when standing at its maximum distance from the Sun. The combination of all these 'stars' visible at the same moment is in $87 \mathrm{BC}$. This constellation may represent the personal horoscope of Antiochos, similar to that on the Lion stele discussed above. If the Lion horoscope was also actually made in $109 \mathrm{BC}$ and thus has to be connected to Mithridates I, this implicates that the younger king wanted to imitate and surpass his father in one and the same time.

The second hypothesis concerns the symbols of the four elements:

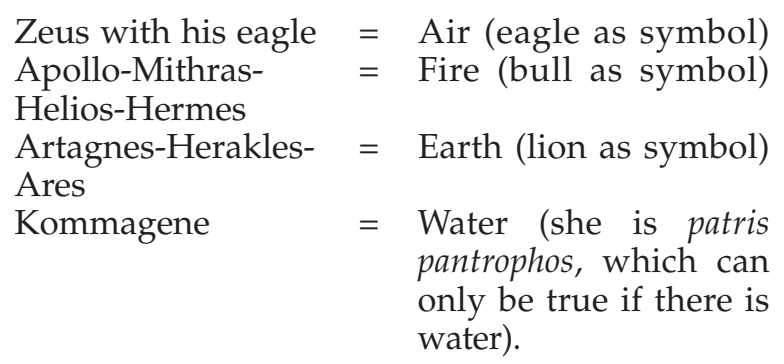

In this way the set of four gods was complete and Antiochos could share the four-some. The pairs of animals embrace the ensemble and repeat the important link between Zeus and Herakles and, now, Zeus and Antiochos and/or Herakles and Antiochos. Moreover, sitting next to Kommagene, Antiochos forms a couple with her as his own country. In this reasoning, Apollo remains the least explicable figure despite his many other names: was here the Persian element of Mithras predominant?

Finally, it is important to notice that there may also be a more general explanation for the choice of these gods. In the Hellenistic period in general especially the trio Zeus, Apollo and Herakles was related to kingship and the ruler, as is witnessed, amongst other things, by the prominent place these gods hold in Alexandrian poetry. By choosing this trio Antiochos thus placed himself in a royal, Hellenistic tradition, presenting himself as a typical Hellenistic ruler. The portrait of Kommagene, and that of the king himself, added a local touch. 


\subsubsection{Style and iconography}

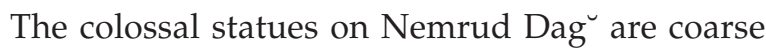
works of sculpture apart from the heads that show a great interest for detail despite their huge measures. Thrones, boots, and clothes: few details enrich the figures. The only additions are the fruits in Kommagene's lap, her cornucopia, Herakles' stubbed club and the mane of the lion. In sum, the surfaces are plain for the most part. The East Terrace statues are still simpler than their counterparts.

The heads, as said, show a certain degree of detail and some of them even are refined works despite their measures. The head of Antiochos on the East Terrace has remained unfinished as has been observed before by Young. ${ }^{87}$ Antiochos has his ears not worked out and the lappets of his tiara are left unadorned. He has exceedingly roundish cheeks and the small lips stick out of the smooth surface like the lips of a fish. The mouth is closed, whereas all other figures have parted lips. ${ }^{88}$ It seems plausible, therefore, that Antiochos was waiting for the last treatment, especially concerning the ears. His face contours are roundish and should have been reduced slightly as well.

The heads of the colossi of both terraces are similar only, not identical. The beards of Zeus and Herakles of the West Terrace are richer and contain more curls than those of their counterparts. A substantial difference concerns the execution of the Kommagenes: the west one is younger, more elegant than the east one. In fact, that is true for the whole set of heads on the West Terrace.

It seems logical to surmise that the heads were made separately from the bodies, probably in a workshop. The differences in style and execution of the heads could be explained by assuming that artisans with different skills executed the job in a large studio. It is unnecessary to postulate different data or different masters.

The fact that one figure remained unfinished may not puzzle us too much. Apparently the monument had to be finished at a certain moment - the king being old as he stated in his text - and one did care no longer for this shortcoming that would remain practically invisible at the great distance. It is easy nowadays to study the details of the heads, standing as they are on the two terraces, but it is really doubtful whether one could distinguish all their determining elements clearly from beneath.

\subsection{The pilot survey (with Anne ten Brink)}

As described more extensively in section 5 , the area below tumulus and terraces was, by means of processional roads and markers, part of the sanctuary and its conception. To understand what was happening on the terraces, we therefore thought it necessary also to study this direct, wider context; especially because some interesting questions remain to be answered. ${ }^{89}$

\subsubsection{Introduction}

The area directly surrounding the mountain was systematically investigated for the first time in the 1950's by Goell and members of her team, and mainly by the topographer Heinrich Brokamp. In mapping the mountain and monument, Brokamp also made a rather basic but reliable map of the circle with a diameter of around $1000 \mathrm{~m}$ around the tumulus. The main information provided by this research was the existence of two processional roads and markers (inscribed and decorated stelae) as well as a route to a spring in the valley where the nearest source of water was be to found. No traces at all were found of what we could call construction places and activivities (as, for instance, accomodation for the people building the monument) or other facilitaties for a sanctuary in use (as, for instance, lodging places or little stations on the way up).

The aims of the 2001 survey around the mountain were modest. First of all we wanted to check whether the information provided by Goell and Brokamp was correct and to look if there was perhaps more to be found. Second, we wanted a more thorough and detailed insight into the area. Third, we looked for pottery and other traces of human occupation. The striking absence of pottery on the terraces itself plays an important role in the discussion whether the sanctuary was ever in use..${ }^{90}$ We hypothesized that the remains looked for on the mountain might be, at least partly, in the area below. This, firstly, in view of the climatological circumstances (every spring huge amounts of melting water run down the mountain) and secondly from observations during the preparation of the season (figs. 32-33).

\subsubsection{Results}

As to our first question, the information provided by Goell and Brokamp results to be correct and rather complete. The procession road stele I is still in situ. There is no trace of the socket of stele II anymore; as Sanders already conjectured, the place was probably destroyed while making the foundations for the modern stairs leading up from the cafetaria. ${ }^{91}$ From another stele, lying 
below the North Terrace, it cannot be determined anymore if it concerns an entrance stele or not (see section 3.3). We did not come across other such remains. We would like to draw attention to a flat area below the East Terrace where possible cuttings from the living rock are visible as well as large blocks of stone. There may have been a quarry of some kind here. In general, the limestone around the mountain gives us the impression that the blocks for the statues could well have been hewn in the direct surroundings.

As to our second question, a more thorough inventarisation of the area proved worthwile. We compiled a plan from the modern cafetaria (southwest) to the area below the East Terrace (northeast). The landscape consists for a large part of an alternation of ridges and gorges. These gorges are formed by the melting water running down the mountain into one or more so-called ice caves. These ice caves form, as it were, a kind of band at this side of the mountain; they continue below the East Terrace and then stretch out further east. The ice caves differ considerably in size. In many, especially the larger ones, the power of the water coming down can be clearly noticed by the extreme weathering of the rock. The perennial presence of water here is witnessed by vegetation at the borders of the caves still abundantly present in August and September. Even in this period the guards working on the mountain fetch blocks of ice from the caves. We numbered the ice caves directly connected with the gorges, but it is important to realise that there were many more, stretching out to the south and east. From the ice caves it is a 20 minutes steep climb up to the East Terrace. The ice caves, providing abundant fresh and cold water all year, thus seem to have been a source of water much nearer than the spring down the Malatya valley.

Our search for remains of pottery and other human occupation, the third objective of the pilot survey, proved to be succesful. In the survey area we found prehistoric artefacts, pottery from later periods, and parts of the monument on the mountain (stelae fragments, tuffit blocks, etc.). In itself this is an important conclusion; however quantities are few, after difficult and intensive searching. Most artefacts are found at the borders

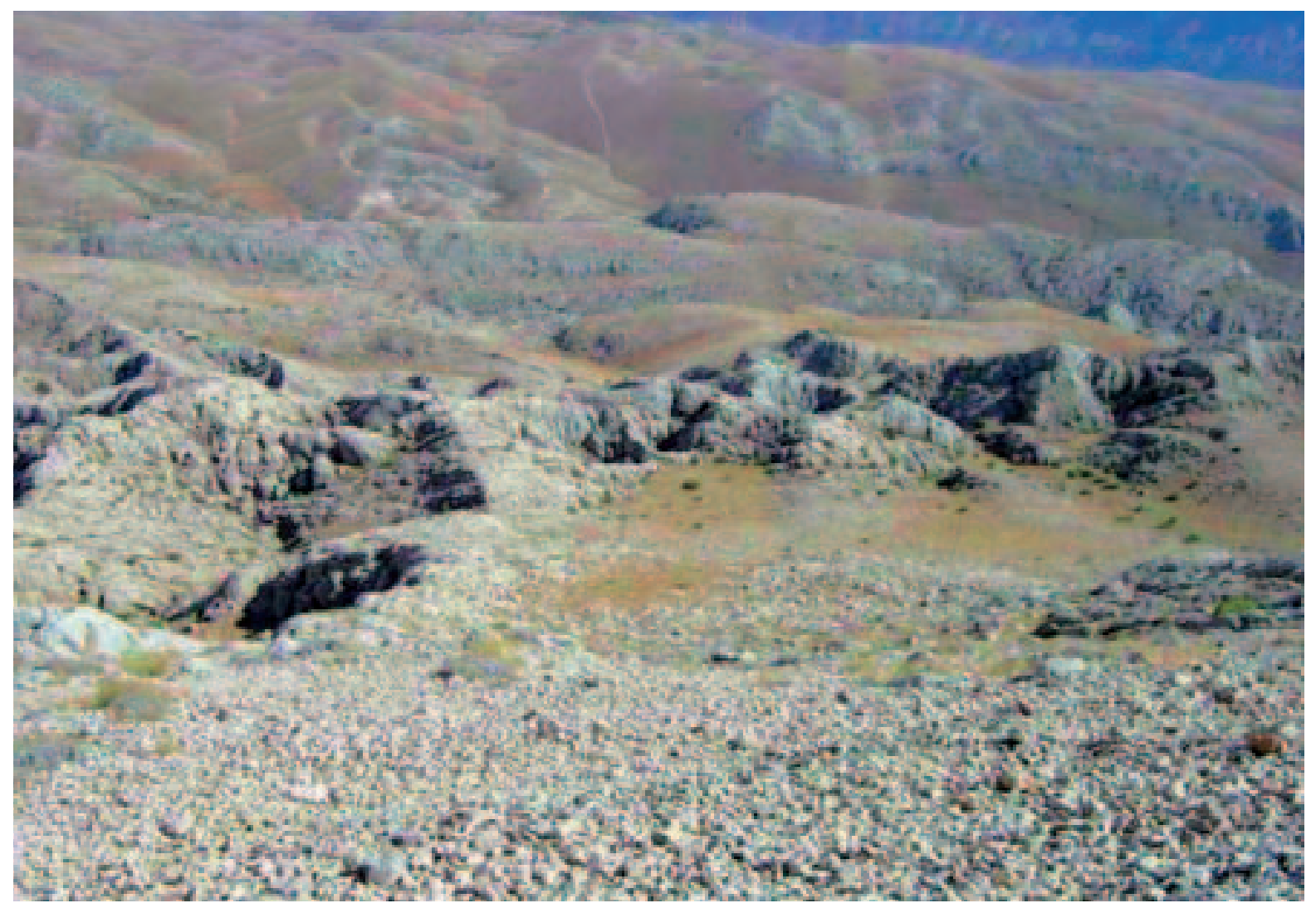

Fig. 32. Nemrud Dă̆g, the survey area (2001, photo A. ten Brink). 


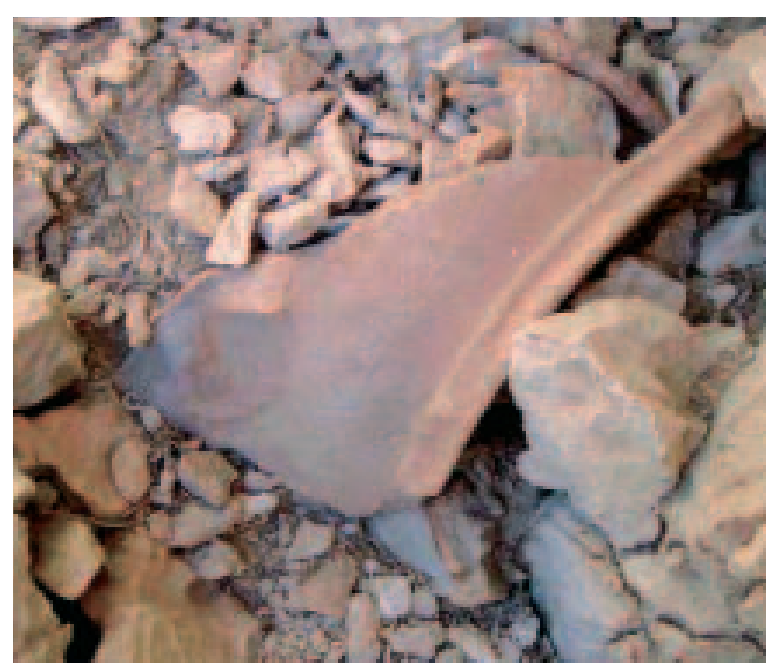

Fig. 33. Nemrud Dă̆, survey find (2001, photo A. ten Brink).

of the gorges. Remarkable is the presence of many small iron slags. The survey database, to be completed next years, will present the finds, supplying a map of the area with the find numbers and further, for every artefact, hand-measured GPS points, a description, dating and photographs. Regarding the prehistoric artefacts and the pottery, the results are too meagre to draw real conclusions at the moment, apart from the general insight that Nemrud Dağ attracted human interest from prehistoric times to the Byzantine period. ${ }^{92}$

It is important to note that the artefacts that have fallen off the mountain cover a very large area. The few tuffit parts of stelae and sockets we found probably come from the East Terrace. They indicate that, again due to climatological circumstances, the present findspots of artefacts fallen down from the terraces only have little to say about their original position.

\subsubsection{Conclusion}

A better knowledge about the area around the tumulus and terraces and the artefacts found there proves to be important for our understanding of Antiochos' monument and for the use of Nemrud Dağ on a larger time scale. Further exploration is thus highly desirable. An extensive field survey, however, seems impossible for practical reasons. The area is extremely rough and there are considerable differences in landscape types which, together with the extreme scarity of the material, makes a more scientific survey in which different areas are statistically compared, impossible.

\subsection{Epigraphic research (Onno van Nijf \& Marlies Schipperheijn)}

The archaeological research programme on Nemrud Dag includes an epigraphic component under the responsibility of Onno M. van Nijf (University of Groningen). During the campaign of 2001 a small team from Groningen has made an inventory of the epigraphic material still in situ. ${ }^{93}$ This material can be divided into three groups:

1. the so-called nomos inscription on the back sides of the colossal statues on the East and West terraces (figs. 7, 26-27) ${ }^{94}$;

2. the inscriptions on the back-sides of the dexiosis reliefs on the West terrace (fig. 34);

3. a small number of fragments on an altar and on scattered stones on the West terrace.

The second group includes a number of palimpsest texts, i.e. inscriptions that have been chiseled over already in antiquity. The original text is at places still visible - if not readily legible. ${ }^{95}$ It has become clear over the course of our investigations that these inscriptions have suffered severely from the extreme weather conditions on the mountain, and from the large number of tourists who visit the site each year. Their condition is deteriorating rapidly (fig. 34).

During the campaign of 2001 we have taken photographs and made paper squeezes of the palimpsest inscriptions, and some of the others. We have focussed on the palimpsest texts, as it was expected that they contain important information on the dating of the complex. Unfortunately, we have not been able to make much progress with the decipherment, due to the bad quality of the text.

Finally, we were able to read two hitherto unnoticed inscriptions in Greek on the bottom of the Herakles' shoulder piece on the West Terrace. 1 :

Under the right arm two letters: $C A$.

The sigma h. 3.5-3.8 cm, w. $2.0 \mathrm{~cm}$, The alpha $\mathrm{h}$. $3.5 \mathrm{~cm}, \mathrm{w} .2 .5 \mathrm{~cm}$.

2:

\section{I $\mathrm{A} \Lambda \Lambda \mathrm{OY} \Delta \mathrm{H} \Sigma \mathrm{THNI} \Theta \Sigma$}

The total inscription is $54.0 \mathrm{~cm}$ long, the letters vary in height between $2.9-4.5 \mathrm{~cm}$ and in width between 2.0- $3.0 \mathrm{~cm}$. Between the first I and the alpha is a space from $4.5 \mathrm{~cm}$. The first I of the last word is doubtful, the theta may be read as an omikron. 
We have not been able to come up with a satisfying interpretation of the texts. It is important to note that these inscriptions would not have been visible once the statue had been erected. The quality of the letters is quite good, which suggests that they may have been a sort of exercise of the stonecutters.

The text may refer to a (local) name, but we have found no paralllels. If we have to read TENIOS, this might be an ethnic. We will comment on this epigraphic material in the next years.

The main aims of the epigraphic project for the future are:

1. the decipherment and interpretation of the palimpsest texts;

2. the collection of all the epigraphic material pertaining to Nemrud Dağ and the interpretation of these documents within a wider cultural and historical framework that includes the other sanctuaries connected to the Kommagenian dynasty.

\section{OUTLOOK FOR THE NEXT YEARS}

One of the main characteristics of Antiochos' hierothesion, and surely one of its most impressive, is the surrounding landscape. Like the hundreds of tourists visiting the place every day at sunrise and sunset, the ancient visitor must have been struck by this visual conquest of nature and will have gazed from the mountain in all directions. To the North the Anti-Taurus continues and one can see the Armenian Highlands; to the East the Euphrates lingers, its valley being clearly visible, to the South where the plains of Syria begin. To the West, after a range of mountains, one can see valleys where, amongst other places, Arsameia with the summer residence of the Kommagenean kings is located as well as Karakus. As several times indicated in our description of the monument (section 3) this natural surrounding had, in many ways, been made part of the concepts and building of the hierothesion. This plan did not only involve the monument proper: Nemrud Dag was the centre of a much larger entity, a grid, as it were, with dynastic cult places on strategic mountain tops in the surrounding, all with a clear

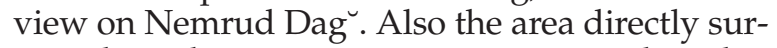
rounding the mountain was integrated in this cultural landscape. As mentioned in the description (section 3) there were marked processional roads leading to the sanctuary from different directions.

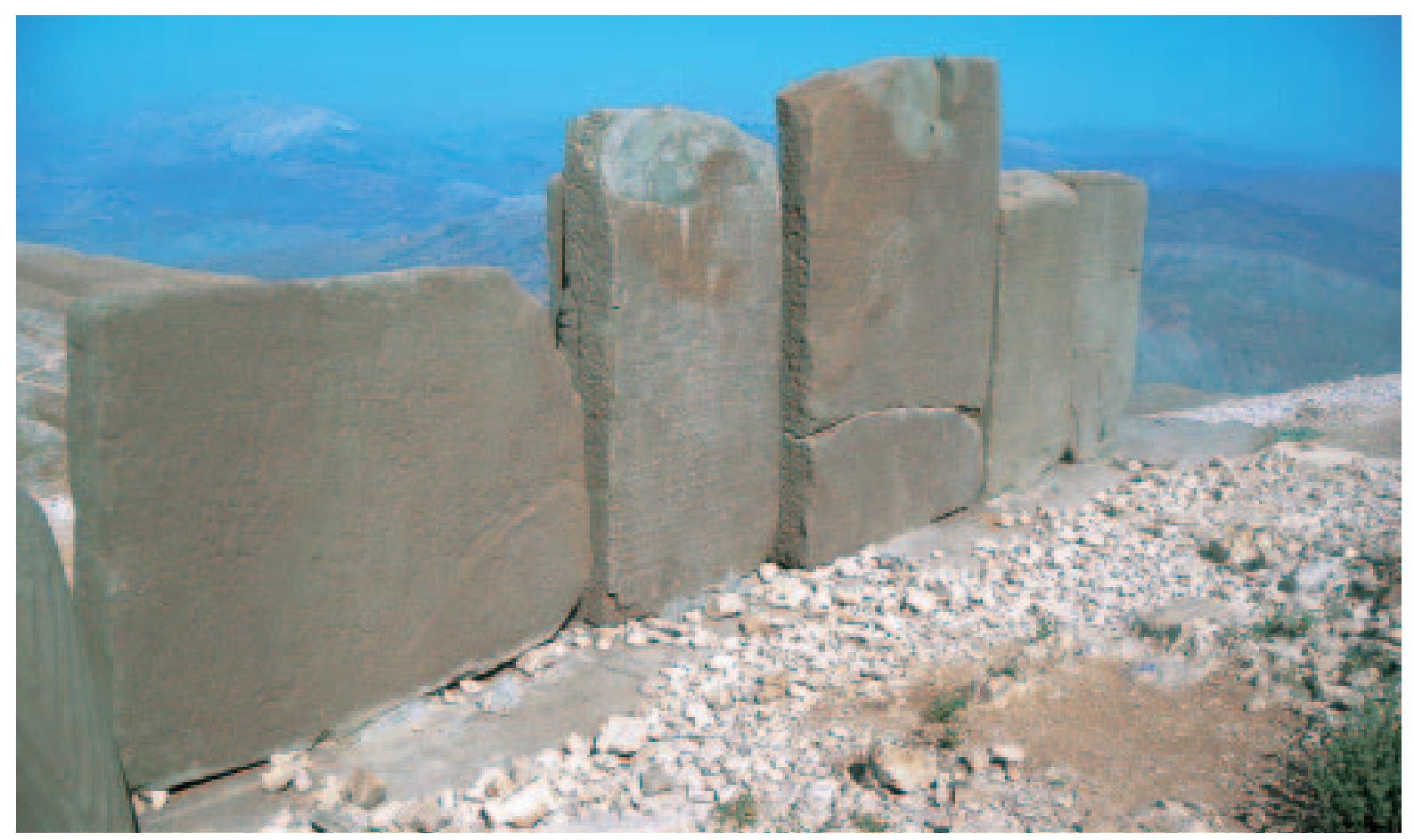

Fig. 34. Nemrud Dă̆g, West Terrace, back side of the reliefs with the palimpsest texts (2001, photo E.M. Moormann). 
For the next years the Nemrud Dağ Project will thus have three areas of interest. First and foremost the Nemrud Dağ hierothesion proper. Our main goal here is restoration and, at the same time, documentation (the SIS) and interpretation. It is striking how few interpretative studies on the monument exist; it is only with the sound essay of Wolfram Hoepfner that we begin to understand the meaning of the place in a wider, Hellenistic context. ${ }^{96}$

The documentation work (the SIS) and interpretative efforts will continue as described for the 2001 campaign. Also some new projects will be started. Most important are the beginning of a structural engeneering project and a stone conservation project. Both will be executed in cooperation with the World Monuments Fund (WMF).

For the 2002 campaign the structural engeneering project aims at:

1. a stabilization of dislocated stones at both terraces (specially at the East Terrace) and a bedrock stabilization of the row of statues;

2. a reconstruction of the base of the lion/eagle pair, in the first instance on the north side of the East terrace, which will be done by consolidation of the existing part with necessary repair and/or strengthening and re-building of damaged parts using dry stone masonry;

3. anastilosis of the eagle statue on the prepared base.

This first part of the engeneering activities should also be considered as a pilot project by which methodology and techniques will be established and appropriate equipment will be checked and selected for future conservation and stabilization work. Also some emergency work will be executed, like the stabilization of the bedrock where this is urgently needed (for instance under the Zeus and Antiochos statues on the East Terrace)

The stone conservation project will deal with the condition survey of the monuments on the site, in situ testing of conservation materials and procedures as well as sampling of stone materials for subsequent analysis and laboratory testing. This way we hope to be able to present a risk assessment for the archaeological monument of Nemrud Dağ that will guide our further restoration and conservation activities.

The 2001 campaign established the fact that there is indeed pottery to be found on the mountain. We will therefore continue the survey and, moreover, try to come to a dating of our scarce finds in cooperation with the Leiden Institute for Pottery Technology.
There exists no comprehensive inventory of the artefacts from the monument, now scattered over the mountain itself, the villages around and the museums in Gaziantep, Adıyaman, Ankara, Berlin, etc. We will begin with defining the outlines of an inventory incorporating all artefacts from Nemrud Dağ.

As far as epigraphy is concerned, there will be made detailed 3D digital images of all the inscribed surfaces on Nemrud Dağ, with special attention for the palimpsest texts. For this purpose a sophisticated 3D scanner has been put at our disposal by the Groningen Institute of Archaeology.

This large restoration, conservation and documentation project will be contextualised by the study of the area around the mountain, the second point of interest, as well as, thirdly, the Kommagenean landscape and archaeological remains in a wider sense.

\section{NOTES}

1 Composition of the team: professor Herman A.G. Brijder, project manager, professor Eric M. Moormann and dr Miguel John Versluys, acting project managers, drs Tesse D. Stek and Ellen Thiermann, SIS, all University of Amsterdam; professor Onno M. van Nijf and Marlies Schipperheijn, epigraphists, University of Groningen; ir. Hans Garlich and ing. Marinus Kremers, geodesists, Technical University Delft; Anne ten Brink, prehistorian, ir. Maurice L.A. Crijns, project coordinator, ir. Jaap Groot, constructing engineer, ing. Willian A.M. van den Bogaard, Auto CAD, engineer and virtual reconstructions, drs. Petronella J.M. van den Mortel, drawings and virtual reconstructions, all INF; Dipl.-Ing. Klaus-Dieter Kiepsch, 3D laser-scan, Callidus Precision Systems, Halle (Saale); Nurhan Turan and Levent Vardar, representatives Ministry of Culture of Turkey. We would like to thank the Turkish Ministry of Culture for its kind cooperation, especially Dr. Alpay Pasinli for his personal commitment to the project. Also the great help of Halil Işik, governor of the province of Adiyaman, and of Bülent Akarcali is acknowledged with gratitude.

2 Sanders 1996.

3 See already the (critical) review by B. Jacobs, AM 30 (1998) 339-346.

4 See Sanders 1996, 26-32 for a more extensive overview of previous research.

5 D.J. van Lennep (1774-1853), Disputatio de regibus Commagenes et Ciliciae Seleucidarum posteris, lecta D. XVII mensis augusti et VIII mensis decembris MDCCCXXVIII, no place, no date; Th. Mommsen, AM 1 (1876) 27-36. Both publications already mentioned by Wagner 2000, 11. Van Lennep presents an overview of the history of the area and its kings from the beginning of the $3^{\text {rd }}$ century BC onwards. In some cases coins are used as pieces of evidence but the research is soundly historical and based on the study of ancient sources like Josephus' Antiquitates and Dio's Roman History. Van Lennep even wrote another essay on this region: 
Disputatio de rege Bostreno aliisque rebus memoratis in Epistula Ciceronis ad Q. fratrem lib. II, 12. Lecta in Instituti Regii Belgici classe tertia d. XV mensis Augusti MDCCCXXXI (n.p., 14 p.) on the city of Zeugma.

6 For information on Dörner and an overview of his publications, see his Festschrift edited by S. Sahin, E. Schwertheim, J. Wagner 1978, Studien zur Religion und Kultur Kleinasiens, Leiden. The excavation of Arsameia, all in all the most thoroughly investigated Kommagenean site, was published in two volumes: Dörner/Goell 1963 and Hoepfner 1983.

7 See the list of expeditions in Sanders 1996, 82-85.

8 Waldmann H. 1973, Die kommagenischen Kultreformen unter König Mithridates I. Kallinikos und seinem Sohne Antiochos I. , Leiden (EPRO 34); idem 1991, Der kommagenische Mazdaismus, Berlin (IstMitt Beih. 37) (note however that his conclusions are disputed and not generally accepted); Şahin 1991.

9 Wagner 2000, with previous literature.

10 Sanders 1996, XVII: ' ... it is clear that Goell and her assistants moved or at least overturned nearly every significant stone on the site. Thus, the current position and associations of such stones are not reliable guides to original site conditions.'

11 The best reconstruction is Utecht/Lütjen/Stein 1993, esp. fig. 5.

12 Such a bank made with large blocks is visible behind the colossi on the East Terrace.

13 See Utecht/Lütjen/Stein 1993.

14 Hoepfner 2000, 65.

15 To indicate them, we will further only use their first (i.e. Greek) designation.

16 The right foot of Zeus' throne is resting on some tuffit slabs.

17 Sanders 1996, 392 sees them as attributes used during prayers and offerings. In that case our figures are 'spendende Götter'.

18 Sanders 1996, 158.

19 Sanders 1996, 248, 448-449 (coronation), 252-253 (fragments of Lion Horoscope, including the stars' names). On the plateau see Sanders 1996, 106-109.

20 Sanders 1996, 104-105.

21 Sanders 1996, 159 n. 37.

22 For a definition of tuffit cf. section 3.4.

23 Sanders 1996, 230-231, fig. 266-267.

24 Sanders 1996, 123, 230.

25 In the following we describe them as if they were completely preserved.

26 Sanders 1996, 397-398.

27 This practice is clearly visible on the head seen in profile of the king on the dexiosis stele with Apollo.

28 This detail is hardly recognisable, but was observed and analysed by Goell (Sanders 1996, 200, 388, 470).

29 Re-use was already observed by Goell: Sanders 1996, $121,232,254$, see further our section 4.4 .

30 The stelae have been erected by Dörner in 1984 (Sanders 1996, 163 note 66). The base was slightly restored: the original situation can be seen on Sanders 1996, fig. 304.

31 For a detailed description see Sanders 1996, 232-254.

32 Sanders $1996,396,401,410-413$, only pointing at this feature specifically on page 445 .

33 Sanders 1996, 121, 248 fig. 272-277. Cf. p. 234.

34 Goell feels a sense of humour in this detail and compares the ears to those of rabbits (Sanders 1996, 242-243).

35 Sanders 1996, 244.

36 Sanders 1996, 306: Goell replaced the altars; 355 (inscription).
37 In Sanders 1996, 254-355 (both terraces). See on the ancestor stelae most recently Messerschmidt W. 2000, Die Ahnengalerie des Antiochos I. von Kommagene, in: Gottkönige am Euphrat, 37-43 and Jacobs B. 2000, Die Reliefs der Vorfahren des Antiochos I. von Kommagene auf dem Nemrud Dağı - Versuch einer Neubenennung der Frauendarstellungen in den mütterlichen Ahnenreihen, IstMit 50, 297-306.

38 Sanders 1996, 128

39 Sanders 1996, 94.

40 For a short characterisation of both stone types see Düppenbecker/Fitzner 1991. Sanders 1996 uses the term 'sandstone' throughout his work to describe the 'tuffit'. Sanders 1996, 156, note 21 vaguely hints at the place of the tuffit quarry. M. Crijns drew our attention to the spot.

41 Some cuttings in this small mountain suggest the presence of rooms, probably for officials or guards.

42 Sanders 1996, 192, fig. 129.

43 See Sanders 1996, fig. 100. Diameter shoulder socket 54 $\mathrm{cm}$, diameter tenon $48 \mathrm{~cm}$.

44 This peculiarity is also observed in Sanders 1996, 420, fig. 165. A similar incision can be seen on a block of the left eagle on the East Terrace. Other differences between the colossi of both terraces are listed in Sanders 1996, ibidem 449-454. He concludes (p. 454) that the colossi are identical despite these small differences.

45 To give some examples, on the West Terrace, the heads of Zeus, Kommagene and, Antiochos have four holes, Apollo has two holes, the eagle has three holes (the southern one has the beginning of a fourth at one side).

46 As a parallel one can point at the reconstruction project recently undertaken in the sanctuary in Xanthos (Lycia, Turkey) where the temple of Leto is being reconstructed with $80 \%$ of the blocks still present, cf. Archéologia $1 / 2002,15 \mathrm{ff}$.

47 This work was carried out by members of the Technical University Delft, cf. for a detailed account Garlich J.H./M.J.M. Kremers, GPS-RTK mapping of Nemrud monument, Geodesia 2002-5, 188-193.

48 This work has not been done yet; finishing SIS level 2 for the East Terrace is one of the goals of the 2002 campaign (see further section 5)

49 See for this aspect in general Beck R. 1962, Epiphanes of the great gods: astrology in the royal cult of Commagene, Toronto.

50 The following experts helped to tackle the problem of the Lion Horoscope: J. Meeus, J. Rademaker, C. de Jager (Space Research Organization, Utrecht), and G. Schilling (Artis Planetarium, Amsterdam).

51 C. Robert, Eratosthenis catasterismorum libri XII (1878) esp. 96.

52 Humann/Puchstein 1890, 331-336.

53 Humann/Puchstein 1890, 330

54 Still starting from the premise that the date had to be found within the first half of the $1^{\text {st }}$ century BC. Cf. Neugebauer O./H.B. van Hoesen, 1959, Greek Horoscopes (= Memoirs of the American Philosophical Society, 48), Philadelphia, esp. 14-16 cat. no. 61

55 Sanders 1996, 172.

56 W. Haase, AW Sondernummer 6, Kommagene (1975) 21.

57 Tuckerman B., 1962, Planetary, Lunar and Solar Positions 601 B.C. to A.D. 1, Philadelphia.

58 O. Neugebauer had calculated this date as a possible option.

59 The sequence of these heavenly bodies as depicted on the Lion horoscope is different (from right to left: 
Moon, Jupiter, Mercury and Mars) due to the differing velocities of their circulation.

60 Humann/Puchstein 1890, 346.

61 A handy chronological table can be consulted in Wagner 2000, 25. The last date differs: one also finds 38 and 32.

62 East IA, 20-24; text in Sanders 1996, 208.

63 Young 1964 (heads); Şahin 1991, 116 (utensils); Hoepfner 2000, 66; B. Jacobs, IstMit 50 (2000) 303.

64 Goell (in Sanders 1996, 232) thought that Antiochos probably had planned a nomos text, later replaced by the text we see nowadays. No chronological consequences were drawn from this observation.

65 No stele portraying Antiochos himself has been found. According to Jacobs 2000, 48-49 Antiochos did not erect an image of himself in this series because he was placed among the gods. Notwithstanding Jacobs' dating of the whole monument to the reign of Antiochos (p. 34-35), this may be true.

66 The work can have been done in a rather short lapse of time. Utecht/Lütjen/Stein 1993 point at the relatively small amount of energy and work needed to construct the tumulus with its layer of gravel.

67 See most recently Wagner 2000, 18, 21-22.

68 Sanders 1996, 449.

69 Wagner 2000, 23-24 points at the simple forms of the Karakuş tumulus.

70 Waldmann 1973 (see n. 8), 54; Sahin 1991, 115.

71 Sanders 1996, 141-143 and 163 n. 65; Jacobs 2000, 35; Hoepfner 2000, 66.

72 Hoepfner 2000, 67.

73 Hoepfner 2000, 65 considers these steps as 'Sitzstufen für Zuschauer in der Art einer Theateranlage'. Even if the idea is plausible, one may wonder that the attendants could not see the statues which played a fundamental role in the setting (and perhaps in the ceremonies to be celebrated).

74 Sanders 1996, 106: 'a row of five sandstone reliefs flanked at the north and south ends by a group composed of free-standing lions and eagles'.

75 See Sanders 1996, figs. 318-322 (Lion horoscope fragments) and 234-235 (other fragments).

76 Humann/Puchstein 1890, plate XXII.

77 According to one of our local informants, who practiced the catchment of kekliks, these birds are catched by luring birds to another put into a cave and there is no need of a large built construction.

78 Hoepfner 2000, 65: 'Zentrum der Kulthandlung ist in jedem Heiligtum ein Altar, auf dem der große Opfer vollzogen wurde...' But the idea of a 'fire altar' is 'Folge einer willkürlichen Bezeichnung'. The participants were to sit on the plateau under the statues.

79 Utecht/Lütjen/Stein 1993, fig. 14, no. R2.

80 Apparently Hoepfner 2000, 70-71 does not object to the concept of an altar, comparing it to a pantheon at Kamiros.

81 This element seems not to have been changed during the restoration work by Dörner in 1984 (see Sanders 1996, fig. 271), as becomes clear from Sanders 1996, fig. 304. Sanders 1996, 163 note 66 tells that Dörner even had tuffit blocks made for the basis. For Dörner's restoration see Sanders 1996, fig. 271.

82 Humann/Puchstein 1890, 282.

83 The drawings, however, show the old sequence (e.g. fig. 87), which makes the reading of Goell's work rather confusing.

84 A fragment of the tip of Antiochos' tiara of the East Terrace lies near the Kommagene head.
85 Antiochos helped Pompey with 200 archers in his battle against Caesar (Caesar, Bell. Civ. III 4; Appian, Bell. Civ. II 49), cf. Sanders 1996, 23; Wagner 2000, 25 (time table).

86 Hoepfner 2000, 68 considers the choice as free, done at random. He follows the idea of a pantheion as proposed in older publications.

87 Young 1964. We seriously consider the possibility that the Apollo (fig. 11) was left unfinished as well because of the extremely roundish outlines and the fish-like closed lips. Whether true or not, it doesn't detract from the general conclusions.

88 This peculiarity is also observed in Sanders 1996, 453, but without drawing any conclusions out of it.

89 The pilot-survey was planned, set-up and executed by Anne ten Brink and Miguel John Versluys.

90 See, for instance, Şahin 1991.

91 Sanders 1996, 153 note 9. On the entries and the stelae Sanders 1996, 94-96.

92 On the terraces Goell found in all years of excavation some six Roman and Byzantine coins, see Sanders 1996, 472-474.

93 Remains and fragments of inscriptions that were discovered by earlier campaigns are now dispersed over a number of Turkish and other musea.

94 Publications: Humann/Puchstein 1890, 262-278; Cumont II 1896, 89-91; Michel 1900, 735; OGIS 383, 591603; Laum 1914, 148-153; Waldis 1920, 3-11; IGLS I, 1929, 12-26; Dörner 1953, 143-146; Waldmann 1973, 6171; Sanders 1996, 207-213.

95 Puchstein already noticed this palimpsest as is clear from a footnote in description of the Zeus-stele: 'Unter dieser grossen Weihinschrift habe ich bei gewisser Beleuchtung auf der glatt gewaschenen Fläche des Steins bisweilen lange Reihen kleiner Buchstaben wahrzunehmen geglaubt, ohne dass es mir möglich war, irgend einen bestimmten Buchstaben zu erkennen. Auf einem Abklatsch dieser Fläche is dergleichen jedoch nichts zu bemerken.' (Humann/Puchstein 1890, 325).

96 Hoepfner 2000.

\section{BIBLIOGRAPHY / ABBREVIATIONS}

Dörner, F.K./T.B. Goell 1963, Die Ausgrabungen im Hierothesion des Mithridates Kallinikos von 1953-1956 (IstForsch 23), Berlin.

Düppenbecker, V./B. Fitzner 1991, Gesteineigenschaften und Verwitterungszustand der Monumente auf dem Nemrud Dă̆, in Nemrud Dağ - Neue Methoden der Archäologie, Bönen, no page numbers.

Gottkönige am Euphrat = Wagner, J. (Hrsg.) 2000, Gottkönige am Euphrat. Neue Ausgrabungen und Forschungen in Kommagene, Mainz am Rhein.

Hoepfner, W. 1983, Das Hierothesion des Königs Mithridates I. Kallinikos von Kommagene nach den Ausgrabungen von 1963 bis 1967 (IstForsch 33), Berlin.

Hoepfner, W. 2000, Arsameia am Nymphaios und der Allgötterkult Antiochos I. Schriften, Bilder und Säulen als Zeugnisse späthellenistischer Kultur, in Gottkönige am Euphrat, 56-73.

Humann, K./O. Puchstein 1890, Reisen in Kleinasien und Nordsyrien, Berlin.

Jacobs, B. 2000, Das Heiligtum auf dem Nemrud Daği. Zur Baupolitik des Antiochos I. von Kommagene und seines Sohnes Mithridates II., in Gottkönige am Euphrat, 26-35. 
Şahin, S. 1991, Forschungen in Kommagene, Epigraphica Anatolica 18, 99-132.

Sanders, D.H. (ed.) 1996, Nemrud Daği. The Hierothesion of Antiochos I of Commagene. Results of the American Excavations directed by Theresa B. Goell, I (text), II (illustrations), Indiana.

Utecht, T./H. Lütjen/B. Stein 1993, A Short Note on the Geophysical Survey of 1989 at the Archaeological Site of Nemrud Dagh, Turkey, in Vogel A./G.N. Tsokas (eds.), Geophysical Exploration of Archaeological Sites, Wiesbaden, 24 pp., no page numbers.
Young, J. H. 1964, Commagenian Tiaras: Royal and Divine, AJA 68, 29-34

Wagner, J. 2000, Die Könige von Kommagene und ihr Herrscherkult, in Gottkönige am Euphrat, 11-25.

AMSTERDAMS ARCHEOLOGISCH CENTRUM

NIEUWE PRINSENGRACHT 130

NL-1018 VZ AMSTERDAM 